INTER NATIONAL MONETARY FUND
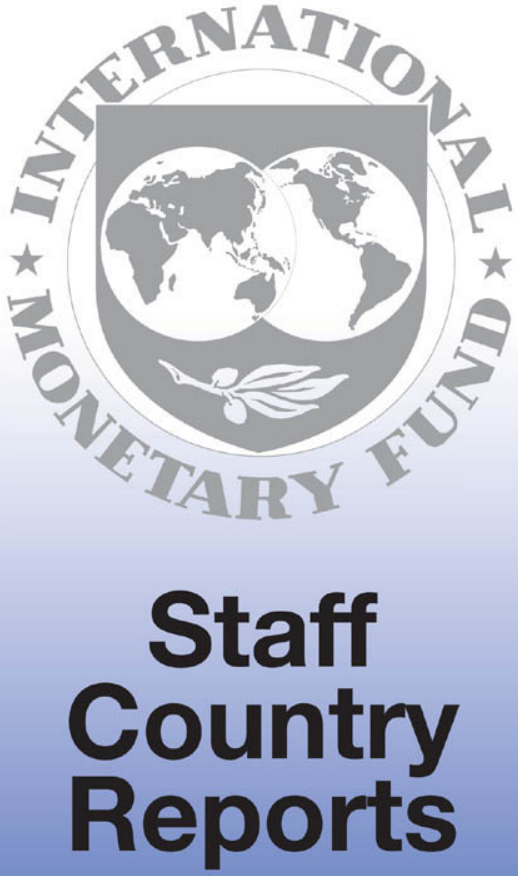


\section{Gabon: 2001 Article IV Consultation-Staff Report; Staff Statement; and Public Information Notice on the Executive Board Discussion}

Under Article IV of the IMF's Articles of Agreement, the IMF holds bilateral discussions with members, usually every year. In the context of the 2001 Article IV consultation with Gabon, the following documents have been released and are included in this package:

- the staff report for the 2001 Article IV consultation, prepared by a staff team of the IMF, following discussions that ended on December 18, 2001, with the officials of Gabon on economic developments and policies. Based on information available at the time of these discussions, the staff report was completed on March 7, 2002. The views expressed in the staff report are those of the staff team and do not necessarily reflect the views of the Executive Board of the IMF.

- a staff statement of April 1, 2002 updating information on recent developments.

- a Public Information Notice (PIN) summarizing the views of the Executive Board as expressed during its April 1, 2002 discussion of the staff report that concluded the Article $\Gamma$ consultation.

The document listed below has been or will be separately released.

Selected Issues and Statistical Appendix Paper

The policy of publication of staff reports and other documents allows for the deletion of market-sensitive information.

To assist the IMF in evaluating the publication policy, reader comments are invited and may be sent by e-mail to Publicationpolicy@imf.org.

Copies of this report are available to the public from

International Monetary Fund - Publication Services

$70019^{\text {th }}$ Street, N.W. - Washington, D.C. 20431

Telephone: (202) 623-7430 • Telefax: (202) 623-7201

E-mail: publications @ imf.org Internet: http://www.imf.org

Price: $\$ 15.00$ a copy

International Monetary Fund

Washington, D.C. 
INTERNATIONAL MONETARY FUND

\section{GABON \\ Staff Report for the 2001 Article IV Consultation}

Prepared by the African Department

(In consultation with the Fiscal Affairs, Legal, Monetary and Exchange Affairs, Policy Development and Review, Statistics, and Treasurer's Departments)

Approved by Jean A.P. Clément and Liam P. Ebrill

March 7, 2002

- A mission visited Libreville during December 6-18, 2001 to conduct the 2001 Article IV consultation discussions and the fourth review (based on the end-September test date) under the 18-month Stand-By Arrangement approved by the Executive Board on October 23, 2000.

- A mission that visited Libreville during September 6-18, 2001 could not conclude the third review (based on the end-June test date), owing to fiscal slippages and delays in key structural reforms, notably in the governance area.

- The first and the second reviews were concluded on July 13, 2001 (EBS/01/56; 4/12/01, and $\mathrm{EBS} / 01 / 56$, sup. $1 ; 7 / 10 / 01)$.

- The arrangement was treated as precautionary in 2001 , as the average world oil price (US\$24.3) was above US\$23 per barrel.

- Meetings were held with the Ministers of Finance, Defense, Education, Health, and Family Affairs; the National Director of the BEAC; other senior government officials; donor representatives in Libreville; the National Social Security Fund; and the employers' association.

- The staff team consisted of Messrs. Kouwenaar (head), Ntamatungiro, and Söderling (all AFR). The mission was assisted by Mr. Ebrahim-zadeh, the Fund's Resident Representative in Libreville. Mrs. Kabedi-Mbuyi, Advisor to the Executive Director for Gabon, also participated in the policy discussions in December 2001. 
II. Background and Recent Economic Developments

A. Political Situation ..............................................................................................

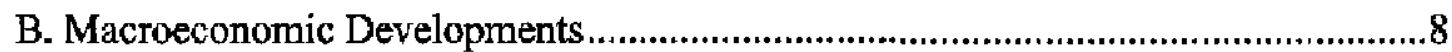

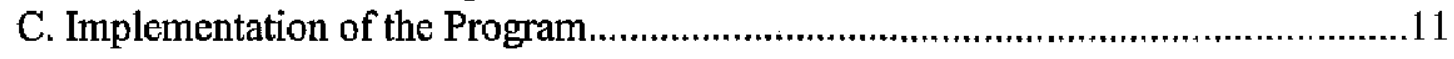

III. Policy Discussions for 2002 16

A. Macroeconomic Outlook and Context of Discussions........................................16

B. Fiscal Policies for 2002 ..............................................................................17

C. Monetary and Financial Sector Policies .........................................................21

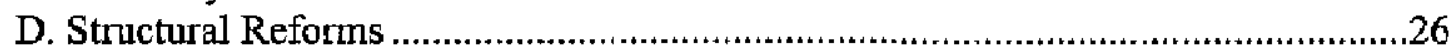

E. Medium-Term Outlook .....................................................................................32

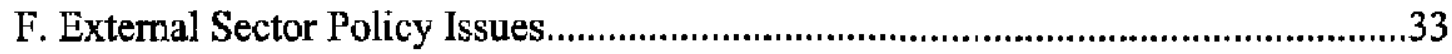

G. Statistical Issues .............................................................................................34

IV. Staff Appraisal

\section{Text Tables}

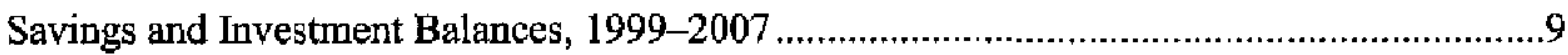

Framework for the 2002 Budget ...............................................................................17

$\underline{\text { Boxes }}$

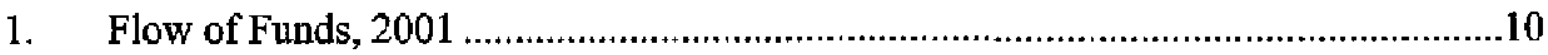

2. Indicators of Fiscal Consolidation, 1996-2001 ...............................................13

3. Taxation of Domestic Petroleum Consumption and Excises.......................................19

4. Structural Fiscal Reforms-Recent Progress and Agenda …..................................22

5. Transparency in Financial Relations Between the Government and Enterprises .........23

6. Financial System Stability Assessment ....................................................................25

7. National Social Security Fund - Problems and Agenda for Rehabilitation...................27

8. Domestic Pricing and Business Licensing Regulations............................................30

9. Poverty Reduction Strategy …..................................................................................

\section{$\underline{\text { Figures }}$}

1. Government Fiscal Operations, 1993-2002 …................................................38

2. $\quad$ Selected Real and External Sector Indicators, 1993-2002 ..................................39

3. Nominal and Real Effective Exchange Rates, January 1993-November 2001 ..........40 
Tables

1 Selected Economic Indicators, 1998-2007 ...................................................41

2. Fiscal Operations of the Central Government, 2000-02 ..................................43

3. Quantitative Performance Criteria and Benchmarks Under the Stand-By

Arrangement, 2000-01 ..........................................................................45

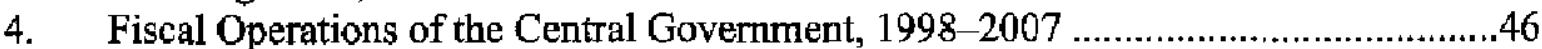

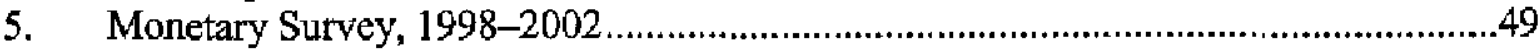

6. Balance of Payments, 1997-2007 ............................................................51

7. External Public Debt Outstanding and Scheduled Debt Service, 1998-2007 …........53

8. Medium-Term Balance of Payments Outlook, 2000-07 ......................................55

9. Income and Social Indicators, 1970-99 ........................................................56

10. Prior Actions and Structural Performance Criteria for $2000-01$..............................57

11. Structural Benchmarks for 2000-01 .............................................................59

Appendices

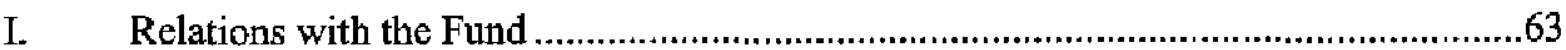

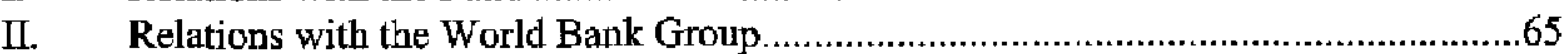

III. Bank of the Central African States: Safeguards Assessment.................................68

IV. Statistical Issues .................................................................................................. 


\section{EXECUTIVE SUMMARY}

\section{Recent economic developments}

- Macroeconomic developments were favorable in 2001. Oil production and prices were higher than projected, and there was a pickup in real growth in the non-oil sector. Activity benefited from significant government repayments of domestic debt. Inflation remained under control at about 2 percent.

- During 2001, the authorities continued their efforts to consolidate public finances, with the primary fiscal surplus reaching some 17 percent of GDP. However, this outcome was below the program target and, combined with sizable unprogrammed outflows on the financing side, led the government to resort to bank financing that was much bigher than programmed. This, in turn, was the main factor behind the large decline in net foreign assets.

- The primary surplus was largely used for external debt-service payments, which represented about 40 percent of government revenue. The considerable fiscal adjustment effort during 1999-2001 has helped to reduce significantly government debt.

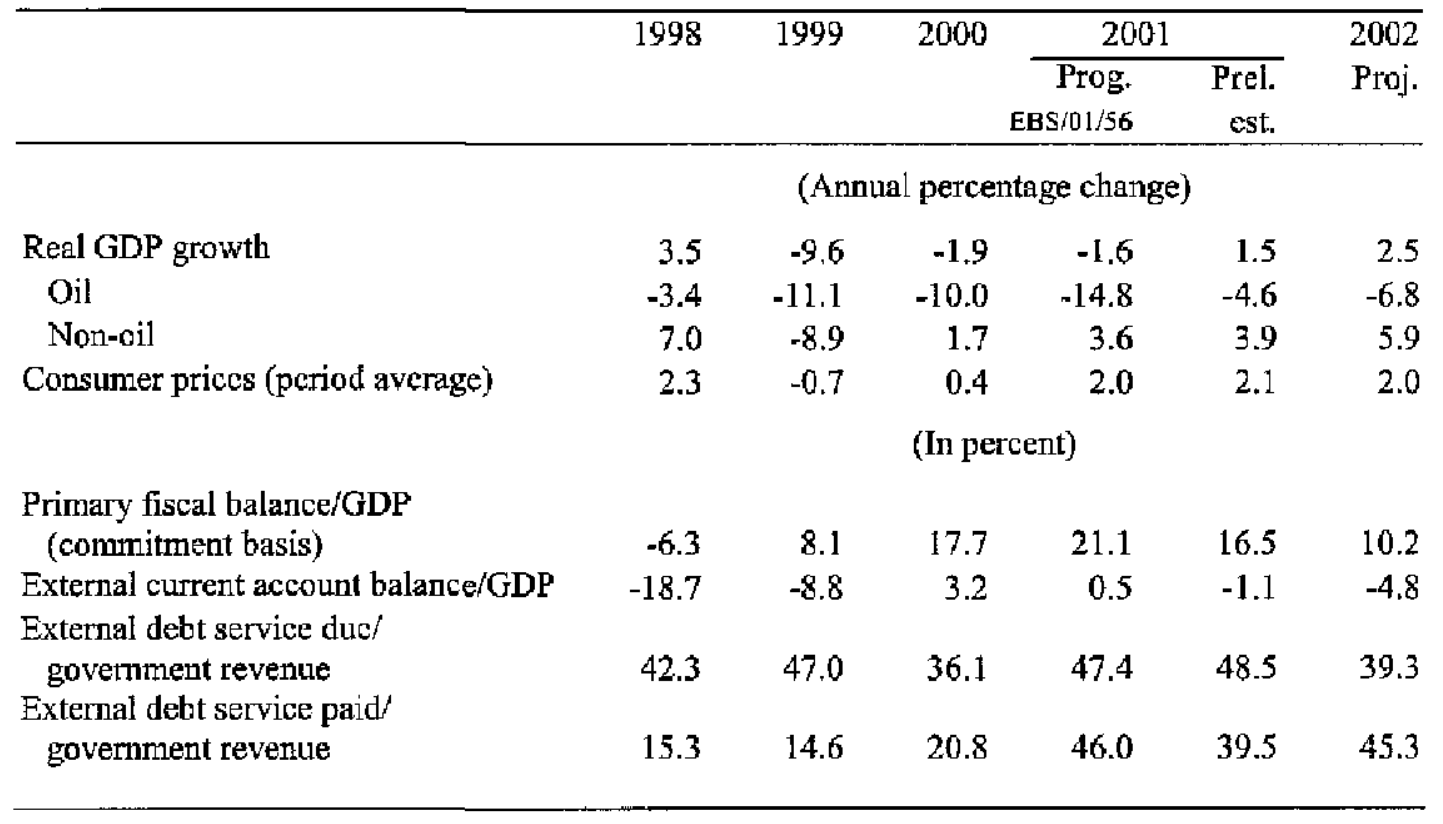

\section{Implementation of the Stand-By Arrangement-supported program}

- The first and second reviews under the 18-month Stand-By Arrangement approved on October 23, 2000 were concluded on July 13,2001. Owing mainly to non-oil revenue shortfalls, the provision of unforeseen financial support to public enterprises, and large withdrawals from treasury accounts, three quantitative performance criteria and 
benchmarks (primary fiscal balance, net credit to goverument, and external arrears) for end-June, end-September and end-December 2001 were missed by relatively large margins. Moreover, there were delays in the implementation of key structural reforms, notably in the area of governance. As a result, the third, fourth, and fifth (final) reviews were not concluded.

\section{Report on the discussions}

- Gabon's main challenges in the medium term remain the projected sharp decline in oil production and the high external debt service burden. As a result of declining oil revenue, scheduled external debt service payments will continue to represent around 40 percent of government revenue. These challenges call for a strengthening of fiscal and structural reforms in order to diversify Gabon's economic base and reduce poverty-

- Policy discussions centered on fiscal consolidation, public finance management, governance, and structural reforms. The authorities emphasized that the high external debt service in 2002 and beyond remained a major obstacle for adequately increasing public investment, which in tum was necessary for improving Gabon's weak social indicators. They argued that a new Paris Club rescheduling under more favorable conditions was needed. The staff underlined that this would require a good track record in fiscal policies and governance, in conjunction with the formulation and implementation of a poverty reduction strategy.

- The budget law for 2002 adopted by parliament in mid-November 2001 included a reduction in government savings and a large unfinanceable gap. However, preliminary understandings were reached with the authorities on a framework for a revised 2002 budget that entails significant revenue measures, savings on nonsocial current expenditure, and more gradual increases in public investment, in line with improvements in expenditure management and the formulation of a poverty reduction strategy.

- The authorities concurred with the staff that the deepening of fiscal and structural reforms, essentially in the areas of governance, transparency of public finances, and the environment for private sector activity, was critical for the diversification of Gabon's economy. They saw a new medium-term program as an instrument for carrying out these reforms.

\section{Issues highlighted in the staff appraisal}

- The authorities' steps to improve public finances, regularize relations with extemal creditors, and reduce public debt are an indication of progress toward medium-term fiscal sustainability. However, the fiscal slippages recorded in 2001 and the delays in implementing the structural reforms under the program point to the need for strengthening expenditure management and enhancing program monitoring. 
- Medium-term prospects for growth and poverty reduction depend crucially on the extent to which the non-oil sector can replace the rapidly declining oil sector. Achieving such an objective will require sustained fiscal consolidation and significant improvements in governance and the efficiency and equity of government spending. However, given the heavy external debt-service burden, the success of such a strategy will also depend on Gabon's obtaining a reduction in its debt-service burden during the coming years.

- The staff welcomes the authorities' intention to prepare a revised 2002 budget that would be in line with the government's objective of fiscal and debt sustainability in the medium term. The authorities are encouraged to step up their efforts to improve transparency in oil revenue, to strengthen customs and tax administration, to contain the wage bill, and to ensure that investment projects are fully consistent with the priorities of the interim poverty reduction strategy paper.

- The staff welcomes the progress made in the implementation of structural reforms, particularly in public expenditure management. However, stronger efforts are required, notably in the areas of governance (anticorruption laws, the procurement code, and full implementation of the integrated budget information system), civi] service reform, privatization, and the regulatory environment for the private sector.

- Despite the underimplementation of the fiscal and structural reform program during 2001, Gabon's underlying efforts over the last few years to put public finances on a sound footing and regularize relations with external creditors represent an achievement. The authorities are encouraged to regain the momentum of fiscal and structural reforms, which could lay the basis for discussions on a new medium-term program that could obtain the support of the international community. 


\section{INTRODUCTION}

1. In concluding the 2000 Article IV consultation with Gabon on October 23, 2000, the Executive Board noted that the remedial measures taken since 1999 in the areas of governance, transparency, and fiscal management had helped improve confidence in government actions. They also pointed to the heavy external debt-service burcen, the excessive dependence on oil revenue, and the disturbingly weak social indicators. They encouraged the authorities to pursue their adjustment efforts in the context of the Stand-By Arrangement-supported program, with a special focus on fiscal consolidation that would free up resources for critical investment in economic and social infrastructure, on the fight against corruption and improved governance, and on the acceleration of other structural reforms, so as to foster economic diversification, job creation, and poverty reduction.

2. Following completion, on July 13, 2001, of the first and second reviews under the 18-month Stand-By Arrangement approved on October 23, 2000, the remaining reviews could not be completed because of fiscal slippages and delays in key structural reforms, notably in the governance area. The staff proposes to let the Stand-By Arrangement lapse on April 22, 2002.

3. Gabon's economic database is fairly comprehensive, and data are generally compiled in accordance with international standards. However, as indicated in Appendix IV, much remains to be done to improve the quality, consistency, and timeliness of data. Gabon's recent intention to participate in the General Data Dissemination System (GDDS) should help address the existing shortcomings.

4. The World Bank has assisted Gabon under a privatization and regulatory capacitybuilding technical assistance loan approved in 1997, has provided support for the forestry sector and environment, and is expected to be involved in the preparation of a poverty reduction strategy paper (PRSP).

5. Gabon has accepted the obligations of Article VIII, Sections 2, 3, and 4 of the Articles of Agreement and maintains an exchange system that is free from restrictions on the making of payments and transfers for current international transactions. Gabon is on the standard 12-month Article IV consultation cycle. Relations with the Fund and the World Bank are summarized in Appendices I and II, respectively. Appendices III, IV, and V include the safeguards assessment, statistical issues, and the background section of the public information notice (PIN), respectively.

\section{BACKground AND RECENT ECONOMIC DEVELOPMENTS}

\section{A. Political Situation}

6. The President's ruling party (Parti Démocratique Gabonais, or PDG) and its allies won the parliamentary elections held in December 2001 with 107 of the 120 seats in the National Assembly. A government of national unity was appointed on January 27, 2002, consisting of 39 cabinet members (up from 33), and including four ministers from the two 
main opposition parties. Municipal elections scheduled for April 2002 will immediately be followed by the election of a new Senate.

\section{B. Macroeconomic Developments}

7. Following the modest recovery in non-oil output during $2000^{1}$-from the severe economic recession of 1999__ cconomic activity strengthened further during 2001, and non-oil GDP is estimated to have grown by some 4 percent, slightly above program projections (Table 1). The pickup in private sector activity, helped by significant reductions in government domestic debt, was strongest in the commerce, agriculture, and wood processing sectors. Buoyant activity in the latter sector helped offset a decline in world demand for Gabon's logs that resulted from the worsening world recession after the September 11 events. Oil production stood at some 13 million tons, close to its 2000 level (13.5 million tons), instead of declining by nearly 15 percent as projected under the program. This favorable outcome reflected higher-than-anticipated world oil prices, which made profitable the exploitation of marginal oil fields. As a result, overall real GDP growth is estimated to have been $1 \frac{1}{2}$ percent in 2001 , as opposed to a decline of similar magnitude anticipated under the program. ${ }^{2}$

8. Broad money and credit to the economy expanded by $7 \frac{1}{2}$ percent and 17\% percent, respectively, in 2001 (Table 5). Owing mainly to higher-than-programmed net credit to government (by 4.3 percent of GDP), net foreign assets declined by some 35 percent of beginning-of-period broad money. Consumer price inflation remained subdued, at about 1 percent during the 12-month period ended December 2001. The real effective exchange rate appreciated slightly in 2001 (Figure 3).

9. The authorities continued their efforts to consolidate public finances, and, helped by favorable oll revenue, the primary fiscal surplus reached the equivalent of some 17 percent of GDP in 2001 (Tables 2-4 and Figure 1). However, this outcome was below the program target of 21 percent of GDP, largely because of non-oil revenue shortfalls and unprogrammed transfers to public enterprises. The primary surplus was to a large extent used for external debt-service payments (14 percent of GDP and almost 40 percent of government revenue).

10. The external current account deteriorated to a deficit of 1 percent of GDP in 2001 (from a surplus of 3 percent of GDP in 2000 and compared with a surplus of 0.5 percent of GDP projected under the program) (Table 6). The trade surplus fell sharply on account of lower oil prices, weaker forestry exports, and a strong increase in imports, the latter of which was associated with non-oil activity and a less tight than envisaged fiscal

\footnotetext{
${ }^{1}$ For developments in 2000, see EBS/00/203 (10/6/00) and EBS/01/56 (4/12/01).

${ }^{2}$ The estimated nominal GDP in 2001 exceeded the program projection by about 10 percent, resulting in correspondingly lower-than-programmed ratios relative to GDP.
} 
stance. The services balance improved, as lower factor payments in the oil sector more than compensated for the increase in interest on public debt.

11. In 2000 , the significant improvement in the national savings-investment balance had largely reflected the increase in government savings, fed by favorable oil prices (see table below). ${ }^{3}$ In 2001, despite continued high oil prices, the government national savings-investment balance deteriorated by nearly 10 percent of non-oil GDP, mainly because of lower oil revenue, higher domestic transfers, and higher external interest payments. The national savings-investment deficit of the oil sector (after tax and dividend payments - - largely determined by new direct investment by foreign oil companiesnarrowed somewhat in 2001. Private non-oil investment continued to increase-by over 2 percentage points of non-oil GDP in 2001 - as confidence strengthened. The higher

Savings and Investment Balances, 1999-2007

(In percent of non-oil GDP)

\begin{tabular}{|c|c|c|c|c|c|c|c|c|c|}
\hline & 1999 & 2000 & 2001 & 2002 & 2003 & 2004 & 2005 & 2006 & 2007 \\
\hline \multicolumn{10}{|l|}{ Total economy } \\
\hline Current accoumt balance & -14.2 & 6.3 & -1.8 & -7.4 & -7.3 & -8.1 & -7.2 & -7.5 & -6.0 \\
\hline Resource balance & 33.3 & 61.6 & 37.6 & 19.3 & 14.4 & 10.7 & 8.8 & 6.3 & 6.2 \\
\hline \multicolumn{10}{|l|}{ Government } \\
\hline Savings-investment balance & 1.9 & 22.9 & 13.2 & 7.6 & 8.6 & 7.8 & 7.5 & 6.4 & 5.5 \\
\hline Investment & 6.7 & 6.0 & 7.4 & 10.6 & 8.1 & 7.7 & 7.6 & 7.5 & 7.2 \\
\hline National savings (including oil revenue) & 8.6 & 28.9 & 20.6 & 18.2 & 16.7 & 15.5 & 15.2 & 13.9 & 12.7 \\
\hline \multicolumn{10}{|l|}{ Of which } \\
\hline Domestic savings (including oil revenue) & 18.4 & 39.1 & 34.6 & 25.2 & 22.5 & 20.7 & 19.7 & 17.8 & 16.2 \\
\hline Domestic savings (excluding oil revenue) & -2.4 & -5.2 & -5.7 & 2.1 & 3.5 & 5.6 & 7.3 & 8.6 & 8.9 \\
\hline Oil revenue & 20.8 & 44.3 & 40.3 & 23.1 & 19.0 & 15.1 & 12.4 & 9.2 & 7.3 \\
\hline \multicolumn{10}{|l|}{ Oil sector } \\
\hline Savings - investment balance & -14.3 & -16.5 & -13.8 & -10.5 & -9.4 & -8.3 & -6.7 & -5.7 & -4.2 \\
\hline Investment & 18.1 & 21.0 & 18.8 & 15.5 & 13.3 & 11.4 & 9.1 & 7.6 & 5.7 \\
\hline National savings & 3.7 & 4.6 & 4.9 & 4.9 & 3.9 & 3.1 & 2.4 & 1.9 & 1.4 \\
\hline \multicolumn{10}{|l|}{ Memorandum item: } \\
\hline Net factur income & -29.3 & -41.4 & -21.9 & -16.4 & -12.5 & -10.3 & -8.1 & -6.7 & -5.6 \\
\hline \multicolumn{10}{|l|}{ Non-oil sector } \\
\hline Savings-investment balance & -1.7 & -0.2 & -1.2 & -4.4 & -6.4 & -7.6 & -8.0 & -8.2 & -7.3 \\
\hline Investment & 14.0 & 16.2 & 18.6 & 18.6 & 19.4 & 19.3 & 19.5 & 18.8 & 18.6 \\
\hline National savings & 12,2 & 16.1 & 17.4 & 14.2 & 13.0 & 11.7 & 11.5 & 10.6 & 11.3 \\
\hline
\end{tabular}

Sources: Gabonese authorities; and Fund staff estimates and projections.

${ }^{3}$ The analysis in this paragraph is in terms of non-oil GDP, as the oil sector can be considered an "enclave," whose domestic economic impact (oil revenue) is comparable to a foreign transfer. 
private investment and the continued large capital outflows were financed by significantly higher private savings and government repayments of domestic debt (Box 1).

\section{Box 1. Flow of Funds, 2001}

The flow of funds highlights the enclave nature of the oil sector in Gabon and the high interest payments on government debt which gives rise to large differences between GDP and income. It also provides a snapshot of the interaction between the private not-oil sectot and the government, which in 2001 was characterized by significant transfers from the government.

- The oil sector has little impact on the non-0il sector other than through payments of oil taxes, which can be compared with a foreign transfer. The oil sector brings its savings out and finances its investments through foreign capital.

- After factor payments, the non-oil sector is left with a disposable income of about U\$\$2,600 per capita, compared with a GDP of about US\$3,750 per capita.

- The government typically generates a significant savings-investment surplus. This characteristic is expected to continue in the medium term although at a declining level.

- In 2001, capital outflows from the private non-oil sector were significant and were mainly financed by govemment repayment of domestic debt and arrears.

- The government paid a signifieant amount of external and domestic debt in 2001, contributing to a substantial decline in net foreign assets.

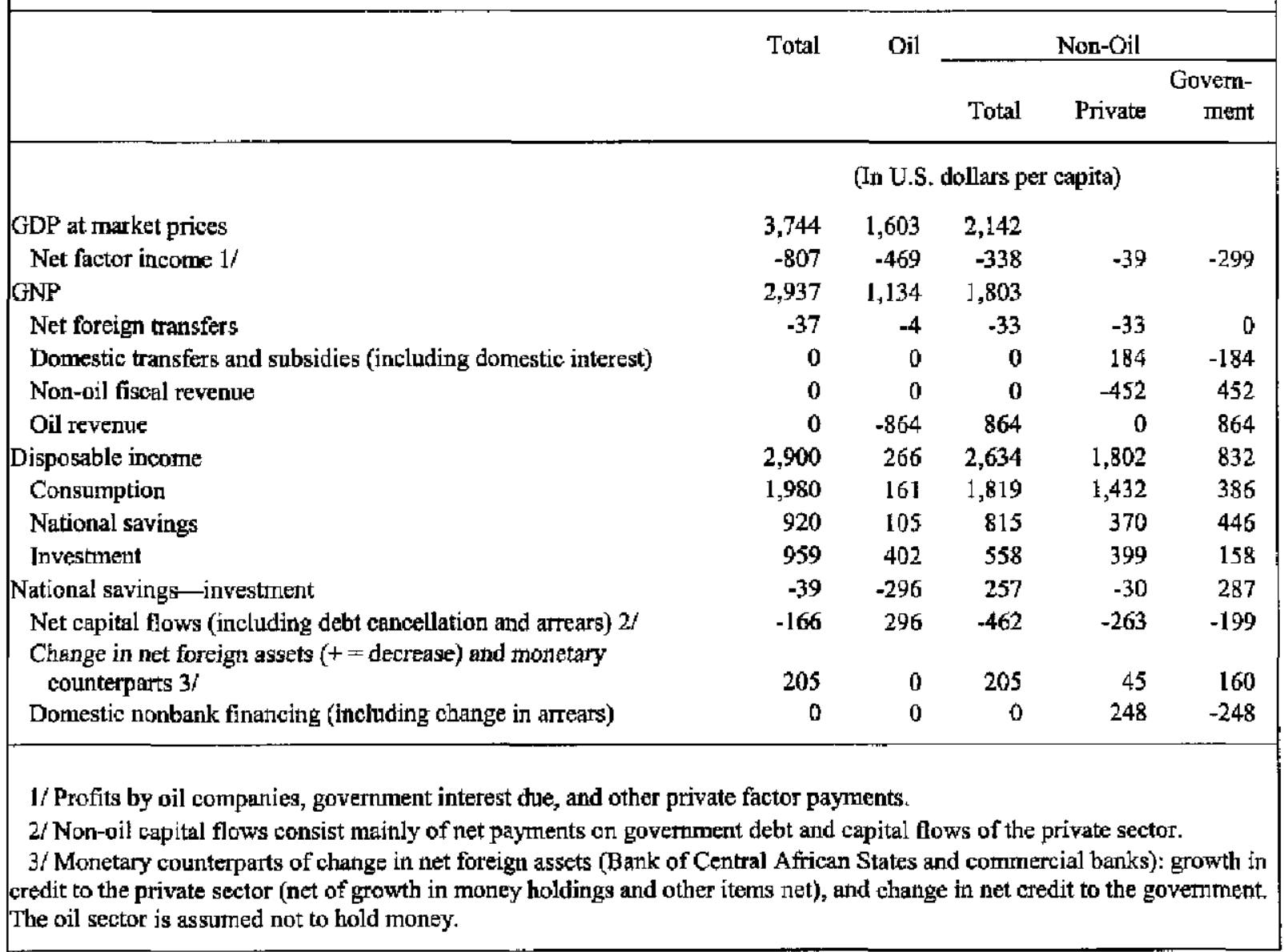




\section{Implementation of the Program}

12. The first and second reviews under the Stand-By Arrangement were concluded by the Executive Board on July 13, 2001, based on performance at end-December 2000 and end-March 2001. At that time, the end-June targets for the primary fiscal surplus and the net bank credit to the government were modified to take into account adverse fiscal developments during the first four months of 2001. However, the fiscal targets for endSeptember and end-December 2001 were kept unchanged, in light of the corrective measures envisaged for the second half of the year (EBS/01/56, sup. 1, p. 17). In the event, non-oil revenue shortfalls and expenditure overruns continued and-combined with unprogrammed withdrawals from treasury accounts--resulted in the nonobservance of most of the quantitative performance criteria and benchmarks for end-June and end-September 2001 (Table 3). In light of this-and of delays incurred in the implementation of key structural reforms (see paras. 17-21)-the third and fourth program reviews were not concluded. These unfavorable fiscal developments continued in the last quarter of 2001 , and three end-December 2001 quantitative performance criteria for the fifth review-for net bank credit to government, the primary fiscal surplus, and external payments arrears-were missed by margins equivalent to 6.8 percent, 3.5 percent, and 1.8 percent of GDP, respectively.

13. Government revenue in 2001 was below the program target by the equivalent of $1 \frac{1}{2}$ percentage points of GDP on account of significant shortfalls in non-oil revenue ( 2 percent of GDP), which were only partly offset by higher oil revenue ( $1 / 2$ of 1 percent of GDP) (Tables 2 and 4). The latter was only slightly above the program target, despite the higher-than-projected production and world oil prices. The authorities explained that the exploitation of marginal oil fields had resulted in significantly higher costs and the average discount for Gabonese oil had become less favorable in 2001. ${ }^{4}$ The disappointing performance of non-oil revenue reflected mainly shortfalls in the collection of customs duties, despite efforts to improve customs valuation and limit exemptions. ${ }^{5}$ The authorities indicated that the program targets-in particular, for customs revenue- bad been very ambitious but also acknowledged that the measures announced in their July 2001 letter of intent were taking longer to produce the anticipated results.

\section{The expenditure overruns (equivalent to $1 \frac{1}{2}$ percent of GDP) were mainly} related to unprogrammed outlays for public enterprises. Owing to delays in privatization, subsidies to two agro-industries (AGROGABON and HEVEGAB) had been higher than programmed, as the authorities - in view of the past unsuccessful offer for sale of several public enterprises-had opted for prior restructuring before offering these companies for

${ }^{4}$ The average discount for Gabonese crude rose from US\$1 per barrel in 2000 to US\$1.8 in 2001.

${ }^{5}$ The effective tariff on imports is estimated to have declined from 27 percent in 2000 to 25 percent in 2001 . 
sale. Unbudgeted equity participations were taken in the private manganese company and the state-owned airline, Air Gabon, to help finance a new manganese-processing factory and to pay for Air Gabon's debt to suppliers, respectively. In mid-2001, the government made the first of the advance payments (for about US $\$ 9$ million) for the purchase of four airplanes for Air Gabon (total contract costs equivalent to 10 percent of GDP). Under the purchase contract signed on May 30, 2001, the government had committed to paying down 30 percent of the total cost and to borrowing the remainder (on nonconcessional terms). The staff pointed out that this purchase, which had not been envisaged in the program, was inconsistent with the government's objectives of debt sustainability and poverty reduction. In line with their commitment in the July 2001 letter of intent to freeze the purchase contract and seek alternative solutions that would minimize government financial involvement, the authorities indicated that they had opted for the conversion of the purchase contract into short-term leasing contracts, an option that had been recommended by the World Bank staff.

\section{Domestic debt repayments were significantly higher than programmed (by} about 1 percent of GDP), and there were unprogrammed outflows from treasury accounts (for a total of some $2 \frac{1}{2}$ percent of GDP) in 2001 . These developments resulted in a large recourse to bank credit, including an overdraft with the Bank of Central African States (BEAC), which was close to the statutory ceiling at end-2001. The authorities explained that advance debt repayments had been made to a major company to allow it to meet its external obligations. They also indicated that, following the 1999 domestic debt audit, some new debt conventions had recently been signed with domestic suppliers. ${ }^{6}$ Outflows from treasury accounts reflected in part drawings by the social security funds, local governments, and autonomous public bodies-all facing financial difficulties, but the remainder is unexplained. ${ }^{7}$ The authorities emphasized that the full coverage of treasury operations by the integrated budget information system (CRYSTAL) from 2002 on would help avoid the recurrence of such unprogrammed withdrawals.

16. Although the authorities in 2001 largely met their very sizable external debtservice obligations (and debt service paid reached 14 percent of GDP), payment delays were incurred, particularly during the second half of the year. ${ }^{8}$ During 2001 , Gabon signed bilateral rescheduling agreements with eight Paris Club creditors and is

\footnotetext{
${ }^{6}$ For details on the audit of the domestic public debt, see Box 2 of EBS/00/203.

${ }^{7}$ Part of these unexplained outflows were incurred toward year's end, and may have to be reclassified as expenditure.

${ }^{8}$ External arrears at end-2001 are estimated at the equivalent of 1.8 percent of GDP.
} 


\section{Box 2. Indicators of Fiscal Consolidation, 1996-2001}

Gabon's fiscal adjustment over the last three years has been significant. The primary fiscal balance turned from large deficits in 1998 to sizable surpluses, with a cumulative adjustment effort representing over 20 percentage points of GDP. This adjustment helped to reduce significantly government debt.

Despite the fiscal slippages recorded during 2001, the government financial position in that year was overall better than in the period immediately preceding the 1998 crisis year. The bulk of the adjustment effort came from sharp cuts in government expenditure, which brought government outlays to close to their pre-1998 levels. There was also some improvement in non-oil revenue collection. The fiscal position appears to have become somewhat less dependent on the oil sector, as reflected in the improvement in the non-oil primary balance and non-oil overall. fiscal deficit, relative to non-oil GDP.

Indicators of Fiscal Adjustment, 1996-2001

\begin{tabular}{|c|c|c|c|c|c|c|}
\hline & 1996 & 1997 & 1998 & 1999 & 2000 & $\begin{array}{r}2001 \\
\text { Est. }\end{array}$ \\
\hline & \multicolumn{6}{|c|}{ (In percent of GDP) } \\
\hline Revenue & 25.9 & 33.1 & 34.5 & 28.7 & 33.8 & 35.1 \\
\hline Oil revenue & 15.4 & 20.7 & 18.8 & 13.0 & 22.8 & 23.1 \\
\hline Non-oil revenue & 10.5 & 12.4 & 15.6 & 15.7 & 11.0 & 12.1 \\
\hline Noninterest expenditure & 17.3 & 25.4 & 40.8 & 20.6 & 16.1 & 18.6 \\
\hline Primary current expenditure & 12.0 & 14.1 & 27.1 & 16.4 & 12.9 & 14.3 \\
\hline Investment and net lending & 5.3 & 11.2 & 13.7 & 4.2 & 3.1 & 4.2 \\
\hline Primary balance & 8.6 & 7.8 & -6.3 & 8.1 & 17.7 & 16.5 \\
\hline External debt service paid, excluding IMF & -5.7 & -6.6 & -4.8 & -3.6 & -6.6 & -13.6 \\
\hline Other financing, net & -3.0 & -1.2 & 11.1 & -4.5 & -11.1 & -2.9 \\
\hline Total debt & 86.5 & 83.9 & 99.2 & 101.0 & 72.3 & 69.9 \\
\hline \multirow[t]{2}{*}{ Of which: external, excluding IMF } & 69.7 & 68.2 & 74.4 & 79.2 & 62.9 & 56.8 \\
\hline & \multicolumn{6}{|c|}{ (In percent of noti-oil GDP) } \\
\hline Non-oil revenue & 19.0 & 21.2 & 21.7 & 25.1 & 21.3 & 21.1 \\
\hline Primary current expenditure & 21.7 & 24.1 & 37.7 & 26.2 & 25.1 & 25.2 \\
\hline Investment and net lending & 9.6 & 19.2 & 19.1 & 6.7 & 6.0 & 7.4 \\
\hline Non-oil primary balance & -12.2 & -22.1 & -35.0 & -7.8 & -9.8 & -11.5 \\
\hline Non-oil overall balance & -23.6 & -32.7 & -45.6 & -18.9 & -21.7 & -27.1 \\
\hline External debt service paid, excluding IMF & -10.2 & -11.3 & -6.6 & -5.8 & -13.2 & -23.7 \\
\hline Total debt & 156.4 & 143.4 & 137.9 & 161.7 & 140.5 & 121.1 \\
\hline Of which: external, excluding IMF & 126.0 & 116.6 & 103.4 & 126.9 & 122.1 & 99.4 \\
\hline
\end{tabular}


finalizing agreements with the remaining three. ${ }^{9}$ The regularization of external debt obligations by Gabon has been made possible by a considerable fiscal adjustment effort during the last three years, as described in Box 2. The bulk of the adjustment (over 20 percentage points of GDP) entailed severe cuts in government expenditure.

17. There was some progress in budget-related reforms, but substantial delays were incurred in the implementation of key structural reforms, particularly in the areas of governance and privatization. Only a few structural benchmarks during the second half of 2001 were met and the one structural performance criterion (on the civil service management system) was not met (Tables 10-11).

18. The integrated budget information system (CRYSTAL) became operational at the central level in early $2001,{ }^{10}$ However, it did not cover special funds ${ }^{11}$ and most treasury operations, while its extension to all ministries and government accounting agencies was delayed from mid-2001 to 2002. A new debt-management unit was created in the course of 2001 and will be fully computerized in early 2002 . A partial public investment review was undertaken in July 2001 with the assistance of the World Bank and other donors. A draft new procurement code-aimed at improving transparency and reducing costs - -was prepared, but adoption was postponed to 2002. For the first time in years, the Auditor General's Office (Cour des comptes) prepared and published its report on the budget execution for 1999. As regards the financial audits of oil companies (a structural benchmark for end-September 2001), the audits for three smaller oil companies were completed, while those for the two largest companies and other smaller ones were delayed to 2002 .

19. On civil service reform, the draft law setting out the new legal framework for the organization of the civil service and the new general statutes for civil servants were adopted by the government—after some delays-in October 2001. Pending adoption by parliament of

\footnotetext{
${ }^{9}$ The consolidated amount under the Agreed Mimutes of the Paris Club of December 2000 is estimated at CFAF 400 billion, about 12 percent of GDP (see Box 1 of EBS/01/56).

${ }^{10}$ CRYSTAL is a computerized management tool that records all stages of budget execution. The new information system should also enable the preparation of accounting balances of the treasury in real time and improve the monitoring of unpaid payment orders at the treasury.

${ }^{11}$ Special funds are accounts fed by earmarked revenue that is spent-thus far outside normal budget procedures - on specific purposes, such as road maintenance, forestry, etc. The number of special funds has remained unchanged during the program period (at 51), with annual receipts of some 1 percent of GDP. The program called for an overhaul of all special funds, the elimination of those not supported by a law or not deemed essential, and the incorporation in the budget of all other ones.
} 
the general statutes, the draft of the specific statutes for civil servants awaits submission to the government. ${ }^{12}$ The introduction of a new computerized personnel and payroII management system (a structural performance criterion for end-December 2001) was delayed and is expected to take effect only in early 2003.

20. The draft anticorruption laws were passed by the Senate in December 2001. The Senate's version took into account most of the staff's earlier concerns, in particular regarding the independence of the Anticorruption Commission, along the lines of the authorities' commitment in their letter of intent of April 10,2001. The staff has brought its remaining concerns to the attention of the authorities. ${ }^{13}$ However, the version adopted by the National Assembly in November 2001 was significantly weaker. The joint committee of the National Assembly and the Senate will address remaining differences before final adoption of the draft laws (in the parliamentary session starting March 2002).

21. There was some progress in privatization, but results fell significantly short of Initial objectives in part because of opposition from various groups and time-consuming decision-making processes. In the agro-industrial sector, a three-year management contract was signed for AGROGABON, while the second launch of bids for HEVEGAB was delayed until the first half of $2002 .{ }^{14}$ After considerable delays, the new regulatory framework for the post and telecommunication sectors was adopted by parliament in May 2001, allowing the Office of Post and Telecommunications (OPT) to be legally split into two entities-Gabon Postes and Gabon Télécom-and the new directors to be appointed in June 2001. The effective liquidation of OPT--and the splitting of its balance sheet and personnel between the two new entities -- has been delayed, and the offer for sale of Gabon Télécom is now expected in late $2002 .^{15}$

${ }^{12}$ Adoption by the government and submission to parliament of the new general and specific statutes were structural benchmarks for end-June 2001.

${ }^{13}$ These concerns are related to the procedures for firing and replacing commissioners of the National Commission Against Illegitimate Enrichment and the transparency of the nonbudgetary funding of the Commission.

${ }^{14}$ Two offers for sale of AGROGABON (in May 2000 and January 2001) and one for HEVEGAB (October 2000) did not attract any bids. The second launch for bids for HEVEGAB was a structural benchmark for end-December 2001 (Tables 10-11).

${ }^{15}$ Issuance of invitations to bid for Gabon Télécom was a structural performance criterion for end-March 2001 in the initial program and later modified to a structural benchmark for end2001. 


\section{POLICY DISCUSSIONS FOR 2002}

\section{A. Macroeconomic Outlook and Context of Discussions}

22. The macroeconomic outlook for $\mathbf{2 0 0 2}$ remains difficult, though overall favorable. Growth in the non-oil sector is projected to pick up further (to over 6 percent), triggered by higher public investment and strong projected private investment (notably in wood processing and construction). In contrast, oil production is expected to continue to drop (by 7 percent) to some 12 million tons, but this would still be above the originally projected level. With world oil prices projected to decline to US $\$ 20$ per barrel (from US\$24.3 in 2001 and compared with US\$21.5 per barrel forecast under the original program), oil revenue is likely to be about one-third lower than in 2001. Overall real GDP growth could reach 2.5 percent in 2002.

23. The policy discussions focused on the 2002 fiscal objectives, taking into account the financial slippages in 2001, the revised macroeconomic environment, the urgent need to improve social services and the physical infrastructure, and the continued heavy debt-service burden. The authorities stressed that lessens from the fiscal underperformance in 2001 needed to be taken into account; in particular, the non-oil revenue targets - which they considered too ambitious under the 2001 program-and the budget allocations for public enterprises-for which they wanted to ensure successful privatization-needed to be realistic. The authorities also emphasized that the continued high external debt service (at about 40 percent of government revenue over the coming years) remained a major obstacle to an adequate increase in public investment, which was, in turn, necessary for improving Gabon's weak social indicators. They stressed that a new Paris Club rescheduling, under more favorable conditions, was needed so as to reduce and spread out the debt-service burden while Gabon pursued its fiscal and structural reform efforts.

24. The authorities agreed with the staff that Gabon's reform agenda remained large and needed to be tackled in the context of a medium-term program ${ }^{16}$ that would focus on further fiscal consolidation (in light of the rapidly declining oil revenue), public expenditure management, good governance, civil service reform, and improvements in the regulatory framework and physical infrastructure for non-oil private sector activity. Such a program - and the financing needs arising from the continued very onerous debt-service burden-could obtain the support of the international community, including through a new bilateral debt rescheduling. However, a satisfactory track record in fiscal policies (including the formulation of a revised 2002 budget), tangible progress in improving governance and transparency in public finance, and the formulation and implementation of a povertyreduction strategy would be prerequisites for such support.

${ }^{16}$ Consistent with the medium-term framework discussed in paras. 49-50 (see Table 1). 


\section{B. Fiscal Policies for $\mathbf{2 0 0 2}$}

25. The budget law for 2002, adopted by parliament in mid-November 2001, envisaged a financing gap of over 9 percent of GDP, reflecting largely increases in primary current and investment expenditure relative to the projection under the original program, and also relative to the 2001 outcome (see table below). The staff noted that this budget was insufficiently supported by revenue measures and that the wide financing gap seemed inconsistent with the government's objectives of fiscal and debt sustainability. While seeing the merit of increasing budget allocations for public investment, the staff advised more gradual increases in public investment, in line with improvements in expenditure management and control, the formulation of a poverty reduction strategy, and the constitution of appropriate budgetary savings.

26. During the December 2001 discussions, the staff reached preliminary understandings with the authorities on a framework for a revised 2002 budget (to be adopted by the new parliament in the session starting in March 2002), which would be

\begin{tabular}{|c|c|c|c|c|c|c|}
\hline \multicolumn{7}{|c|}{$\begin{array}{l}\text { Framework for the } 2002 \text { Budget } \\
\text { (In percent of GDP unless otherwise indicated) }\end{array}$} \\
\hline & \multirow{2}{*}{$\begin{array}{r}2000 \\
\text { Est. }\end{array}$} & \multicolumn{2}{|c|}{2001} & \multicolumn{3}{|c|}{ Budget 2002} \\
\hline & & $\begin{aligned} \text { Prog. } \\
\text { EBS } / 01 / 56\end{aligned}$ & $\overline{\text { Est. }}$ & $\begin{array}{l}\text { Prog. } \\
\text { EBS } / 01 / s 6\end{array}$ & $\begin{array}{r}\text { Budget } \\
\text { Law } \\
2002\end{array}$ & $\begin{array}{l}\text { Staff } \\
\text { prop. }\end{array}$ \\
\hline Oil revenue & 22.8 & 24.5 & 23.1 & 14.6 & 16.2 & 15.1 \\
\hline Non-oil revenue & 11.0 & 15.3 & 12.1 & 16.8 & 16.8 & 16.1 \\
\hline Wage bill & 6.1 & 7.0 & 6.3 & 7.3 & 6.9 & 6.2 \\
\hline Other current, noninterest expenditure & 6.9 & 7.7 & 8.1 & 7.7 & 9.1 & 7.9 \\
\hline Capital expenditure & 2.9 & 4.0 & 3.5 & 4.6 & 7.3 & 6.3 \\
\hline Net lending & 0.2 & 0.0 & 0.7 & -0.1 & 0.2 & 0.6 \\
\hline Primary balance & 17.7 & 21.1 & 16.5 & 12.0 & 9.5 & 10.2 \\
\hline Total financing & -17.7 & -21.1 & -16.5 & -13.4 & -18.5 & -16.2 \\
\hline External (net, including interest before & & & & & & \\
\hline new rescheduling) & -6.3 & -17.2 & -13.2 & -9.6 & -11.0 & -11.7 \\
\hline Domestic (net) & -11.4 & -4.0 & -3.3 & -3.9 & -7.5 & -4.5 \\
\hline Nonbank financing & -6.5 & -4.0 & -7.5 & -2.5 & -6.0 & -2.7 \\
\hline Bank financing & -4.9 & 0.0 & 4.3 & -1.4 & -1.5 & -1.8 \\
\hline Of which: oil revenue deposits, FFG & 0.0 & 0.0 & 0.0 & 0.0 & 0.0 & -1.5 \\
\hline Financing gap & 0.0 & 0.0 & 0.0 & 1.5 & 9.0 & 6.0 \\
\hline \multicolumn{7}{|l|}{ Memorandum items: } \\
\hline $\begin{array}{l}\text { Net external resource transfer (including } \\
\text { the financing gap) }\end{array}$ & -6.1 & -17.7 & -13.7 & -8.5 & -1.9 & -6.1 \\
\hline External public debt (excluding Fund) & 62.9 & 61.8 & 56.8 & 59.9 & 63.6 & 59.9 \\
\hline Nominal GDP (in billions of CFA francs) & 3,577 & 3,098 & 3,387 & 2,948 & 3,157 & 3,157 \\
\hline
\end{tabular}


consistent with the objectives of medium-term fiscal and debt sustainability and poverty reduction. ${ }^{17}$ The proposed budget framework aims at reaching a primary surplus of some 10 percent of GDP and at limiting the financing gap to about 6 percent of GDP. Taking into account efforts under way to increase transparency in the oil sector and reduce leakages, oil revenue collection is projected at the equivalent of 15 percent of GDP. Preliminary understandings were reached on a framework for the detailed and transparent calculations of tax liabilities owed by oil companies under concession and production-sharing contracts. ${ }^{18}$ Given the uncertainty surrounding oil revenue projections, the staff advised caution in the budget forecast, and also recommended that part of the projected oil revenue in 2002 be deposited in the account of the Fund for Future Generations (FFG) at the BEAC, as stipulated in the FFG's statute. ${ }^{19}$ The authorities, however, indicated that the funds to be put aside would likely be below the statutory requirement until the issue of an appropriate return on these resources was resolved. ${ }^{20}$

27. The authorities agreed to revise downward non-oil revenue projections relative to the 2002 budget adopted in November 2001 , to the equivalent of about 16 percent of GDP; this would represent an increase from 12 percent in 2001 and would be achieved through several revenue measures. New tax measures in the 2002 budget or under consideration by the authorities would include (i) increases in export tax rates for logs and manganese from 15 percent to 20 percent and from 3 percent to 5 percent, respectively; (ii) a reduction

${ }^{17}$ The framework for the revised 2002 budget has since been modified slightly to reflect somewhat higher World Economic Outlook (WEO) oil prices in 2002 (from US\$19 per barrel projected in December 2001 to US\$20 per barrel currently projected), updated information on the availability of foreign project financing, and the budget outcome at end2001.

${ }^{18}$ The framework takes into account production volumes and royalty rates by type of contract and quality of crude, actual and projected Brent prices and exchange rates, the discount on Gabon's crude, and estimated costs. Significant uncertainties remain, in particular regarding production cost, depreciation, and the structure of profit sharing. The financial audits of the oil companies will be crucial for refining the framework.

${ }^{19}$ This statute, adopted by law in 1998, stipulates that each year 10 percent of budgeted oil revenue be transferred to the FFG until a minimum capital of CFAF 500 billion (about 16 percent of GDP) is attained, and that half of the oil revenue in excess of the budgeted amount be transferred to the FFG. Under the original program, all of the excess oil revenue was to be transferred to the FFG, but in the event such a transfer was not made in 2001.

${ }^{20}$ The Central African Economic and Monetary Community (CEMAC) has not yet reached understandings on the practical modalities for the management of such funds. Meanwhile, savings for Gabon's FFG will be held in CFA francs in the account with the BEAC (part of net bank credit to government). 
of about one-third in the various sector-specific value-added tax (VAT) thresholds; (iii) an increase in the taxation of the domestic consumption of petroleum products, coupled with a reduction in protection of the national refinery (SOGARA); ${ }^{21}$ and (iv) an increase in the excise rate for beer from 12 percent to 16 percent, together with an increase in the taxable base (Box 3). The staff suggested that the authorities further raise the excise on beer and also introduce excises on soft drinks.

\section{Box 3. Taxation of Domestic Petroleum Consumption and Excises}

The consumption of domestic petroleum products and excisable goods is undertaxed in Gabon by sub-Saharan African standards:

- Taxes on petroleum products (excluding VAT) in Gabon yield revenue of some 0.2 percent of GDP, compared with 0.7 percent in the Repubtic of Congo; 1 percent in Cameroon; 1.6 percent in South Africa; 1.8 percent in Senegal; and 2 percent in Ghana.

- The excise tax rate on beer in Gabon is only 12 percent while beer is taxed at 25 percent in Cameroon, the maximum rate allowed by the CEMAC. Moreover, excises on beer in Gabon apply to the ex-factory value, after a 56 percent rebate. Most sub-Saharan African countries have an excise tax on soft drinks.

- Excises in Gabon yield revenue of some 0.1 percent, compared with some $1 / 2$ of $t$ percent of GDP in Camleroon; 0.8 percent in Ghana; 1 percent in South Africa; and 31/2 percent in Kenya and Nigeria.

- The yields of the new measures in the 2002 budget for domestic petroleum and excise taxes are estimated by the staff at about 0.5 percent of GDP; the yield could reach almost 1 percent of GDP if excises were increased further.

28. Tax administration measures for $\mathbf{2 0 0 2}$ would include (i) improving the collection of customs duties through a stricter control of exemptions and a better valuation of forestry and manganese exports; ${ }^{22}$ (ii) increasing the frequency of the fiscal audits of large enterprises, with external technical assistance, ${ }^{23}$ (iii) reducing leakages in the price equalization system for domestic petroleum consumption; (iv) better controlling personal

${ }^{21}$ The 2002 budget also introduces an income- or turnover-based specific tax to finance road maintenance. The staff has advised against this administratively costly tax and recommended, instead, an increase in taxation of petroleum consumption; this recommendation is now under consideration by the authorities, with World Bank assistance.

${ }^{22}$ The effective utilization of the UN Conference on Trade and Development (UNCTAD) customs software (ASYCUDA) will help improve the valuation and proper monitoring of exemptions.

${ }^{23}$ The staff has proposed that the authorities undertake fiscal audits for all large enterprises (e.g., with annual turnover above CFAF 1 billion, i.e., about 300 enterprises). 
income taxes through the inspection team created in 2001; and (v) incorporating the unit in charge of the government estate (domaines) in the new Direct and Indirect Tax Department.

29. The staff proposed savings on nonsocial current spending (of about 1 percent of GDP) and an increase in public investment to some 6 percent of GDP in 2002 (compared with $7 \frac{1}{2}$ percent of GDP under the 2002 budget law and $3 \frac{1}{2}$ percent of GDP in 2001). The revised 2002 budget would stabilize in nominal terms expenditure on goods and services and transfers. Subsidies to the main public enterprises, pending their privatization/restructuring, would be limited to the equivalent of 1 percent of GDP. ${ }^{24}$ The revised budget would also include provisions for the repayment of one-third of Air Gabon's debt, for the equivalent of 0.6 percent of GDP. The authorities concurred with the staff's recommendation to start reducing the wage bill in line with the ongoing civil service reform (so as to alleviate the burden on the declining government revenue). However, they indicated that, owing to the delays experienced in the adoption of the underlying measures, it would be difficult to reap substantial savings in 2002.

30. The authorities agreed with the staff's recommendation to increase investment spending more gradually, in line with the development of a poverty reduction strategy and the envisaged improvements in implementation and monitoring capacity. The World Bank staff considered the composition of the investment budget for 2002 to be broadly in line with the authorities' overall poverty reduction policy. ${ }^{25}$ However, the staff was concerned about the budget's realism with regard to absorptive capacity, and it recommended that priority be given to the implementation of existing projects and that some new projects be scaled down. The authorities are following up on the World Bank's recommendations, with a view to improving preparation, implementation, monitoring and control of public investment spending. Furthermore, the authorities agreed with the recommendation of both staffs to use, where possible, available foreign project financing.

\section{The authorities and the staff agreed that the revised budget for 2002 would} include moderate provisions for the restructuring and liquidation cost of public enterprises, mainly severance payments for redundancies, as well as an initial repayment by

\footnotetext{
${ }^{24}$ This includes (i) subsidies to the operations of Gabon Postes and assistance for its restructuring; (ii) support for investment by AGROGABON agreed to under the management contract; (iii) assistance to HEVEGAB in the context of its restructuring pending privatization during 2002; and (iv) the government's contribution to the restructuring of Air Gabon.

${ }^{25}$ The 2002 investment budget has increased allocations to health, education, and infrastructure $(16,20$, and 40 percent of the total, respectively, up from 9,8 , and 31 percent in 2001).
} 
the government of public debt owed to the national National Social Security Fund (CNSS), largely premiums in arrears of public enterprises and local governments. ${ }^{26}$

32. The external debt-service (before rescheduling) burden will continue to be heavy in 2002, representing some 45 percent of government revenue, or 14 percent of GDP. ${ }^{27}$ With a primary surplus targeted at about 10 percent of GDP, projected foreign project financing of some 2 percent of GDP, and a net domestic financing need of about $4 \frac{1}{2}$ percent of GDP, the financing gap could be limited to below 6 percent of GDP in 2002. This amount could be financed through a new bilateral rescheduling (largely of previously rescheduled debt) and possible Fund financing under a successor program. In the meantime, the staff recommended that the authorities follow a strict cash management approach by limiting budget allocations for the first half of 2002 to available resources.

33. In the fiscal area, several structural reforms are ongoing (in part delayed from 2001), and the authorities expect to complete them in the course of 2002 (Box 4). In this context, the staff noted that a lack of sufficient transparency in the financial relations between the government and enterprises (regarding taxation, government debt, procurement, and equity participations) was an obstacle to Gabon's fiscal adjustment efforts and would need to be addressed more vigorously, including, where necessary, with technical assistance from external partners (see Box 5).

\section{Monetary and Financial Sector Policies}

34. During 2001, monetary developments were dominated by the unprogrammed use of net bank credit by the government (4.3 percent of GDP, or 27 percent of beginning-of-period broad money), which - as in earlier episodes of government expansion-to a large extent explained the large drop in Gabon's net foreign assets (of 35 percent of broad money) and the 20 percent decline in the overall foreign assets position of the BEAC during 2001 (Table 5). The major deterioration in Gabon's position in the operations account caused its foreign assets coverage ratio ${ }^{28}$ to fall from about 70 percent of reserve money at end-2000 to below

${ }^{26}$ The cash repayments to the CNSS in 2002 have provisionally been set at the equivalent of 0.4 percent of GDP. The exact amount to be paid in 2002 and the following years would be determined by the result of the financial study of the CNSS that is being finalized with International Labor Organization and World Bank support (see Box 7).

27 Although external debt service is projected to fall in 2002 and in the following years, the ratios to government revenue will remain high because of the sharp decline in oil revenue (Table 7).

${ }^{28}$ The coverage ratio for each BEAC country is defined as gross foreign assets with the BEAC (including the country's share in the operations account) over the monetary base. 


\section{Box 4. Structural Fiscal Reforms-Recent Progress and Agenda}

In the fiscal area, the following structural reforms are ongoing:

- The integrated budget information system (CRYSTAL) is expected to become fully operational in early 2002. It will cover financial transactions by all ministries and govemment accounting agencies, all treasury operations, special funds, and domestic debt operations.

- Although transactions on special funds will be covered by CRYSTAL from early 2002 on, the special funds are not yet fully integrated into the government budget. The authorities plan to overhaul all special fumds during 2002 and to incorporate any remaining ones in the budget starting with the 2003 budget.

- The authorities have indicated their commitment to address the shortcomings identified in the publie investment review undertaken, with the assistance of the World Bank and other donors, in July 2001. The preliminary report identified institutional weaknesses in the formulation and the execution of the investment budget, including an irregular updating of sectoral strategies, a lack of coordination between the Ministry of Finance and sectoral ministries, and delays in the communication of budget appropriations to spending ministries, leading to the circumvention of normal procurement procedures and the accumulation of arrears.

- A decree introducing the new procurement code is to be adopted shortly, and a National Commission on Government Contracts (and its secretariat) established. A new Directorate of Public Procurement will be created within the Ministry of Finance. Purchases above CFAF 25 million would require international bids. The authorities estimate possible savings of at least 1 percent of GDP under the code.

- Steps are being taken to strengthen the linanclal control function of the Ministry of Finance. The Directorate General of Financial Control has been strengthened by the creation at end-2001 of the unit in charge of controlling services rendered. Financial controllers will be redeployed from the Ministry of Finance to the spending ministries during the second quarter of 2002. The draft legislation relating to the introduction of the General Inspectorate of Finance is ready and is expected to be adopted shortly by government.

- The Ministry of Finance has initiated the preparation of a new, detailed expenditure classification scheme (economic, administrative, and functional), with technical assistance from Canada. The rew classification scheme is expected to be adopted in the context of the 2003 budget law. As a first step, budgetary spending items have been systematically classified under a common administrative heading system, including those previously recorded under the lump-sum category of "common outlays."

- The financial audits of three smalter oil companies were completed in late 2001. The audits of the two major companies under the concession regime (representing over two-thirds of production) were initiated in March 2002 and are expected to be completed over the next few months, with the help of external auditing firms.

- The Direct and Indirect Tax Department is being restructured and strengthened and will incorporate the unit in charge of government estate (domaines, including oil royalties and dividends). This restructuring will entail a significant increase in the number of tax assessors and controllers. The staff has recommended that the new tax directorate maintain and further strengthen the Large Enterprise Unit. 


\section{Box 5. Transparency in Financial Relations Between the Government and Enterprises}

Gabon's fiscal adjustment efforts have continued to be hampered by a lack of transparency and of a level playing field in the financial relations between the government and foreign-owned and domestic private enterprises. These issues would need to be addressed urgently, where necessary with technical assistance and the collaboration of Gabon's external partners:

- Non-oil sector taxation. The assessment and control of ton-oil exports subject to export taxation are insufficient. For example, there are large discrepancies between the value of manganese recorded at customs and the value recorded in the balance of payments. The profit taxation of all companles is to a large extent based on company declarations only and tax audits have been irregular, in part owing to insufficient capacity. Tax exemptions are widespread and defined in numerous tax conventions with companies. The study of exemptions envisaged under the government's program is still pending. Excise taxation of locally produced beer is subject to a rebate of over one half of the ex-factory value, thus reducing the effective excise rate to less than 6 percent.

- Oil sector taxation. The financial audits of the oil companies-done by the so-called Joint Commission of the Ministries of Finance and Mineral Resources, and called for in the relevant concession- and production-sharing contracts with the companies - have been carried out irregularly, as have tax audits by the tax directorate. The audits of the 1999 and 2000 financial years are still ongoing. The insufficiency of information concerns particularly the production costs, depreciation, and the causes of the varying discounts for several of Gabon's crude oils.

- Government debt. Government arrears to domestic enterprises, related to the 1998 expenditure boom and identified in the 1999 aucits of public finances, were rescheduled over some 8 years under the socalled conventions moratoriées signed around mid-2000 (for a total amount of about 5 percent of GDP). However, in 2001, new debt totaling almost 1 percent of GDP was identified and also brought under these conventions. Debt repayments were made to a major creditor in advance of the agreed schedule, while arrears were accumulated vis-à-vis other creditors.

- Overinvoicing. The 1999 public finance audits identified a pattern of systematic overinvoicing by domestic (largely foreign-owned) enterprises. Deficiencies in procurement and control of services and projects delivered have been only partially remedied, and the practices of overinvoicing and collusive bidding, as well as the deficient implementation of works, have continued.

- Equity participations. The government has participations in over 130 enterprises outside the oil sector, including majority shares in over 30 public enterprises and significant parts in major private enterprises. However, information on dividend receipts in the fiscal accounts is very incomplete, as noted by the Cour des comptes in its report on the 1999 budget execution. In early 2001, the govemment's participation in the French-owned manganese company was increased through a nonbudgeted transfer that maintained its share at 30 percent. Although this company has significant arrears (equivalent to 0.3 percent of GDP) to the recently privatized railroad management company, at the same time-with strong political support-it has been seeking to obtain a controlling minority share in the railroad company. 
10 percent at end-2001 (i.e., well below the minimum coverage of 20 percent under BEAC rules), thereby almost entirely reversing the improvement achieved in $2000 .{ }^{29}$ The growth of private sector credit of 17 percent (up from 12 percent in 2000 ) also contributed to the decline in net foreign assets. The latter development may to some extent be related to capital outflows surrounding the introduction of the euro, as well as the repayment of foreign debt by domestic enterprises following the government's repayment of its debt to these enterprises (para. 15 above).

35. In early September 2001, the BEAC, concerned about the recent increase in inflationary pressures in the subzone and considering the continued high level of bank liquidity, activated the reserve requirements at 0.5 percent for demand (sight) deposits and 1.0 percent for time and savings deposits; it then increased these rates to 1.5 percent and 2.5 percent, respectively, in late December $2001 .^{30}$ At the same time, the $\mathrm{BEAC}$ maintained the interest rate for its money market liquidity absorption operations (TISP) at 3.6 percent and reduced the interest rate for its liquidity injections (TIAO) from 7.0 percent to 6.5 percent. The reserve requirements and unchanged TISP enabled the BEAC to reduce its overall costs of liquidity absorption in the face of declining interest rates on its foreign assets holdings. The staff noted that the reduction in the TIAO was inconsistent with the intention to absorb excess bank liquidity, but the authorities considered that the impact of the TIAO on lending rates was very small ${ }^{31}$ and was meant to help banks in need of refinancing. The staff stressed that, although the BEAC's overall foreign assets position remained comfortable (a coverage ratio of about 60 percent at end-2001, declining from about 70 percent at end-2000), the main source of the recent loss of the BEAC's reserves, namely government credit expansion, would need to be addressed. This would require a significant improvement in the government's net position with the BEAC in 2002, so as to restore Gabon's foreign assets coverage ratio to an adequate level. Furthermore, the authorities would need to prepare for a progressive reduction in the statutory ceiling on the $B E A C$ 's overdraft advances to the government from January 1, 2003 onward of 10 percent each year over ten years and their replacement, as needed, by government securities at market rates.

36. Overall, Gabon's banking sector remained sound in 2001, with high profitability and a small further improvement in the main financial indicators. At end-September

${ }^{29}$ As expected, net foreign assets of commercial banks declined to their normal level during 2001 , as the government used its foreign currency deposits - accumulated from oil revenue in the course of 2000- to pay external debt service deferred to 2001 .

${ }^{30}$ The reserve requirements are uniform for all CEMAC countries and are currently remunerated at 1.2 percent.

${ }^{31}$ Liquidity injection through the BEAC money market operations at the TIAO accounted for less than 1 percent of the subzone's broad money during most of 2001. 
2001 , all five banks virtually met the new minimum solvency ratio of 8 percent, ${ }^{32}$ all but one met the minimum liquidity ratio, and nonperforming loans remained low (between 1 percent and 5 percent of total outstanding credit for four out of five banks and 25 percent for one bank) and adequately provisioned. However, as noted in the Financial System Stability Assessment (FSSA), sectoral and client risk concentration remained a problem for some banks, although the situation improved during 2001 (see Box 6). ${ }^{33}$ In response to the FSAP's recommendations, the CEMAC authorities are strengthening their capacity for on-site and off-site inspections. The Commission Bancaire de l'Afrique Centrale (COBAC) has recently hired 30 new staff and is drafting new regulations for internal and external audits.

\section{Box 6. Financial System Stability Assessment}

Gabon's financial sector, dominated by a relatively sound but small banking sector foeused squarely on the formal sector, operates in an environment characterized by (i) a fixed peg to the euro; (ii) a production structure based on oil and, to a lesser extent, forestry products and manganese, with oil output projected to decline markedly over the next five years; and (iii) a strong role of the government in both the enterprise and financial sectors. Against this background, the recent Financial Sector Assessment Program (FSAP) missions identified, through simulation exercises of possible shocks and through a critical review of the applicable regulations, the following challenges to financial sector stability:

- Solvency levels in some banks are close to the regulatory minimum, and even minor changes in macroeconomic variables could put individual institutions at risk, although overall Gabon's banking sector has been resilient and profitable. This risk is enhanced by the banking sector's portfolio concentration. However, contagion seems contained, owing to limited interbank relations.

- Fiscal problems have had direct and indirect negative repercussions on the performance of the financial sector. The continued exposure of banks to public enterprises and to government suppliers indicates that declines in fiscal revenues-for example, owing to oil price declines and/or from the shrinking output level-can have a negative impact on banks. With oil prices off their highs and government finances deteriorating, these problems bave taken on new urgency.

- In the medium term, with a shrinking oil economy, pressures are likely to emerge that will require structural adjustment in the banking sector, including through diversification, internationalization, and improvements in risk monitoring. These risks seem contained in the short term as a result of ample liquidity and adequate access to central bank refinancing facilities.

- Several significant deviations from best supervisory practices remain despite recent progress: staffing remains inadequate, contributing to continued problems in off-site supervision. The prospective increase in the regulatory minimum capital requirement (from 5 percent to 8 percent by 2004) appears too low, given the operational risks in the economy. Money laundering regulations are not yet in place.

- Deficiencies in the wider legal and regulatory framework pose a threat to financial sector activities. There is a need to ensure consistency between national and regional laws and regulations. Increased efficiency, transparency, and predictability in the disposition of financial sector litigation would reduce risks and costs.

${ }^{32}$ Two banks which had solvency ratios of below 5 percent at end-2000 significantly increased their capital in the course of 2001. The three largest banks account for about 40 , 20 , and 20 percent, respectively, of both total credit and total deposits.

${ }^{33}$ The Financial Sector Assessment Program (FSAP) missions for Gabon were undertaken in June-July 2001 and the outcome discussed with the authorities in the context of the 2001 Article IV consultation. The FSSA report to the Fund Executive Board will be issued shortly. 
37. The regulatory framework for banks in the subzone was strengthened in several ways. In May 2001, the COBAC instituted new regulations for the spreading and coverage of credit risk, including the raising of the minimum solvency ratio from 5 percent to the Basel norm of 8 percent (in annual steps of 1 percentage point between early 2002 and early 2004). Furthermore, the CEMAC Council of Ministers adopted a single registration procedure for banks in the CEMAC zone in July 2001. Finally, the BEAC is formulating rules for banks' net foreign open positions (as recommended by the recent FSAP missions to Cameroon and Gabon), and COBAC is preparing regulations for microfinance (to be adopted shortly) and money laundering (expected to be adopted in the course of 2002).

38. The liquidation of two small banks - each accounting for about $1 / 2$ of 1 percent of total deposits-is well under way. The Banque Populaire du Gabon (BPG)—which had been put under receivership by COBAC in late 1999 - was declared bankrupt in November 2000 after several restructuring attempts had failed. The liquidation-mincluding the repayment of some 3,000 small depositors-is expected to be finalized in the course of 2002, with the losses mainly borne by the nongovernment shareholders. The rural savings and credit bank, Banque Nationale de Crédit Rural (BNCR)-put under receivership in October 2000-was declared bankrupt by $\mathrm{COBAC}$, and the license was withdrawn in November 2001, after several restructuring proposals had been rejected; a liquidator was appointed in January 2002. The losses will be borne by the two main shareholders (autonomous public financial agencies), and the remainder (less than CFAF 1 billion) by the government. Regarding the National Social Security Fund (CNSS), the administrative rehabilitation was initiated in 2001, and the financial restructuring is expected to be implemented in 2002 (Box 7).

\section{Structural Reforms}

39. The authorities emphasized the need to improve further the economic and institutional environment for private sector activity, essential for the diversification of Gabon's economy in the face of declining oil production. They agreed with the staff that the implementation of structural reforms should be accelerated but cautioned that some reforms needed adequate preparation time to ensure broad domestic support and, hence, their success.

40. Regarding privatization, the authorities have adopted a new timetable under the divestiture program supported by the World Bank, taking into account delays incurred and institutional constraints. For HEVEGAB, the appointment in January 2002 of a provisional management under direct control of the Privatization Committee should help minimize financial losses and accelerate the preparation of the offer for sale by mid-2002. For the OPT, the revised timetable foresees the division of personnel and assets between Gabon Postes and Gabon Télécom and the establishment of their opening balances, over the coming months, so as to allow the offer for sale of Gabon Télécom by late 2002. On Air Gabon, the authorities agreed with the staff that it was crucial to deal swiftly and decisively with the excessive debt, which was a severe burden on the liquidity position and increased operational costs of the 


\section{Box 7. National Social Security Fund-Problems and Agenda for Rehabilitation}

The CNSS (Caisse Nationale de Securite Saciale) is a publie agency in charge of social security benefits for employees of the private sector, public enterprises, and local government entities (collectivités locales). ' Workers' benefits covered by the CNSS include mainly pensions, family allocations, health benefits, and professional risks. The pension scheme is based on a "pay-as-you-go system" (système de répartition).

The CNSS' main resources are socjal security contributions that are paid quarterly by employers and employees to the tune of 20.1 percent and 2.5 percent of the employee's gross salary, respectively. About 85,000 employees are enrolled (of which some 15,000 from public enterprises), with annual contributions amounting to around CFAF 50 billion (1/2 percent of GDP), a tumover of about CFAF 55 billion, assets of about CFAF 38 billion, and a stock of debt of CFAF 27 billion.

CNSS experienced serious financial difficulties in past years. This was due to both management problems and the accumulation of arrears in the payment of social security contributions. At end-June 2001, premiums in arrears amounted to some CFAF 70 billion (over 2 percent of GDP), the bulk of which were owed directly or indirectly by the government (public enterprises already liquidated/privatized or under privatization and local government entities). In 2000, the financial situation of the CNSS improved (a net result of CFAF 5.3 billion but without adequate provisioning for legally required reserves), reflecting mainly spending cuts.

The CNSS's situation is Yulnerable, especially given the rapidly aging population (not matched by significant employment creations) and the continued accumulation of arrears on premiums. During 1999-2000, provisions amounted to CFAF 8 billion, well below the required provisions (over CFAF 70 billion). The fund has recently been defaulting on its obligations to 2,000-3,000 enrollees for lack of funds. The CNSS network of hospitals and the pension branch have continuously incurred losses while the family allowance and professional risk branches are generating small surpluses.

The rehabilitation of the CNSS was initiated in 2001, with several steps taken to improve administrative and financial operations, including the establishment of a computerized database on enrollees and employers. Furthermore, an actuarial study, undertaken by the International Labor Organization (ILO) (with World Bank financing) and to be completed shortly, is expected to recommend a restructuring plan and to provide some managernent indicators that should help lead to the CNSS's long-term financial sustainability. The preliminary report of an ILO study on the health sector, completed at end-2001, provides recommendations on management improvements that could help reduce the losses in the CNSS's hospital network. In particular, it proposes a revamping of the existing system of health insurance and a greater participation of users in the financing of health services. The two studies will be complemented by the revisions to the social security laws governing the CNSS and the CNGS that are under preparation.

To accommodate the immediate liquidity needs of the CNSS, the authoritles Intend to make cash repayments in an amount equivalent to about 0.4 percent of GDP in 2002, as a first installment on the repayment of government debt. The exact amount and time schedule for the repayment of the government's remaining debt will be based on the financial restructuring plan -including the consolidation of the govemment's debt, expected to be adopted in late 2002 , following completion of the actuarial study by ILO.

${ }^{1}$ Social security for statutory government employees (fonctionnaires) is handled directly through the wage bill, while government contractuals (and the needy) are covered by the National Social Guarantee Fund (CNGS). 
company; they also concurred that the restructuring efforts of the company should be accelerated, so as to allow its privatization within a reasonable time period.

\section{The authorities agreed with the staff that implementation of the civil service} reform needed to be speeded up. Adoption of the laws setting out the new legal framework for the organization of the civil service and the new general statutes for civil servants is expected in the session starting in March 2002. This should pave the way for the adoption of the new, specific statutes (including a revised salary and incentive system) for civil servants and should remove important legal obstacles to the reorganization of the public administration. The full implementation of the new computerized personnel and payroll management system - which the authorities foresee for early 2003 - will be a prerequisite for an effective reduction in the government wage bill.

42. Regarding governance, the authorities intend to see through the adoption and implementation of the new anticorruption legislation. They also indicated that they would launch the financial audits of the two largest petroleum companies in March 2002, to be completed in a few months. The staff emphasized that more transparent and reliable data on the petroleum sector would help the planning of - and potentially increase - government oil revenue, and that it was important to undertake such financial audits annually, as well as regular fisceal andits.

43. Regarding private sector development, the authorities are envisaging a major reform of the forestry sector ${ }^{34}$ with the support of the World Bank and other external partners. The current World Bank-supported forestry and environment program (which included the formulation of a new forestry code adopted by parliament in November 2001) is expected to be followed by a broader program on renewable resources in 2002 . The program would, inter alia, involve the simplification of the forestry taxation system, ${ }^{35}$ the effective implementation of the new forestry code, improvements in institutional capacity, and the development of a new forestry information system, including to enhance forestry tax collection. An audit of the capacities and roles of various forestry institutions, including the quasi-state monopoly for log exports (SNBG), is under way.

44. The development of the export processing zone (EPZ) on the island of Mandjiprimarily aimed at attracting petroleum service- and wood-processing industries-is

\footnotetext{
${ }^{34}$ The forestry sector contributes about 8 percent to non-oil GDP and nearly 60 percent to non-oil exports.

35 The World Bank has recommended that the number of taxes be limited to those that can be easily monitored (such as, e.g., export taxes and surface taxes). This issue may be revisited in the context of the revised budget for 2002 .
} 
progressing. Since the promulgation of the relevant law in October $2000,{ }^{36}$ the national EPZ commission has been created, and the zone is expected to be operational in 2003. The staff expressed concern regarding the envisaged permanent cap on corporate tax rates and pointed out that the implementation of an EPZ should be accompanied by a general liberalization of the economy, so as to create a level playing field for all economic activities. In response, the authorities indicated that they were considering these issues in consultation with external partners, such as the Intemational Finance Corporation (IFC), and would reexamine the current system of widespread tax and duty exemptions.

\section{The authorities concurred with the staff that the strengthening of the legal} framework governing business and the judicial system remained key to promoting private sector activity. Since the adoption of the Organization for the Harmonization of Business Law in Africa (OHADA) Uniform Acts by the members of the CFA frane zone, some progress has been made in implementation by Gabon, including through national and international workshops to familiarize judges and other concerned parties with the OHADA rules. The government is adapting national laws, where necessary, so as to conform to the OHADA Uniform Acts, including the commercial code. Meanwhile, the OHADA common rules related to commercial law, corporate law, secured transactions, bankruptcy, debt recovery, arbitration, and accounting the already replaced existing laws or are being applied directly in Gabon. ${ }^{37}$

46. The authorities are aware of a number of obstacles affecting the functioning of the judicial system: the lack of training of judges in commercial, banking, and insurance law; the heavy procedures prescribed by the law, automatic rights of appeal, and the resulting large backlog of cases; insufficient publication of judicial decisions; insufficient dissemination of legal procedures and the limited access of citizens to the courts; and inadequate budget allocations for the judicial system. The staff discussed with the authorities the preparation of a study and action plan for strengthening the judicial system, in particular as regards business.

47. Regarding domestic pricing and business licensing, the authorities are aware of the need to further liberalize the regulatory framework. The staff recommended that a high priority be attached to removing remaining price controls (except for a few basic goods) and simplifying business and trader licensing (Box 8).

${ }^{36}$ The law provides tax advantages, including a ten-year exemption from corporate income tax (starting from the time of the full implementation of the EPZ) and a permanent cap of 10 percent thereafter (compared with the current rate of 35 percent).

${ }^{37}$ The Uniform Acts for several other areas, including competition law and banking law, are under preparation by OHADA's permanent secretariat in Yaoundé. In line with the OHADA provisions, Gabon will need to establish commercial courts of first instance (appeals go directly to the OHADA Common Court of Justice and Arbitration in Abidjan). 


\section{Box 8. Domestic Pricing and Business Licensing Regulations}

Background. Since 1989, Gabon has been progressively liberalizing the domestic economy and removing import restrictions. Shortly after the January 1994 devaluation of the CFA franc, the temporary price controls and maximum profit margins were abolished-except for a number of basic goods (including basic food and medical items, petroleum products, beer, and cement) and for all services whose prices remained fixed; quantitative import restrictions were replaced by tariff surcharges; and all import licensing was abolished. The new Competition Law, in effect since July 1998, allows the government to regulate prices in case of anticompetitive practices and for specific goods and services.

Since that time, several price regimes have been in place:

- Prices, which are fixed by ministertal decree or by privatization agreements, malnly: petroleum products; electricity and water; bread; soap, edible oils, and bottled water, ${ }^{1}$ sugar; and cement.

- Prices, which are subject to ceilings that are advised by producers and subject to approval by the price control directorate (DGPEE) of the Ministry of Finance mainly: locally produced beer, nonalcoholic and mixed beverages, locally bottled wine; school manuals; and pharmaceutical products.

- Prices of other goods and services are free but any changes need to be justified and approved by the DGPEE.

The regulatory framework for pricing and licensing is enforced as follows:

- The main functions of the DGPEE are the control of prices and the surveillance of anticompetitive practices. It employs some 50 controllers. In addition, the Directorate of Consumption of the Ministry of Commerce has a largely overlapping role of controling pricing and competitive practices.

- The 1998 Competition Law foresees the establishment of a Competition Commission to advise the government on meesures against anticompetitive practices and imports that could harm actual or potential domestic production. The relevant implementation decrees are under preparation by the DGPEE, which also has the role of disseminating price and competition regulations.

- The Ministry of Commerce is, inter alia, in charge of issuing business licenses, which are necessary for all trading activities and are issued in Libreville and a few other locations in Gabon. In addition to obtaining a business license, each trader needs to register with tax administration and the Ministry of Justice.

- It is the govemment's intention to bring all registration for new businesses together in a single office (guichet unique). For industrial and mining activities, a single agency was established in 2000 (the Private Industry Promotion Agency-APIP) but has not yet become operational.

- Althougb quasi-fiscal levies, not based on a law and collected by the treasury, were abolished by presidential decree in February 2001, in practice, certain levies have remained. Moreover, the customs charges a fee for its information system services (the so-called RUSID, amounting to some 2 percent of the import value).

Agenda for reform. The staff has recommended that the government give a high priority to liberalizing the regulatory framework for domestic economic activity, in particular by:

- ellminating all price controls for goods and services except for a few basic goods and petroleum products and utilities;

- abolishing the price control functions of the relevant directorates of the Ministries of Finance and Commerce, and clarifying their remaining roles in competition policy, so as to avoid overlap;

- making the Competition Commission operational; and

- effectively eliminating the remaining quasi-fiscal levies.

Produced by the public enterprises AGROGABON and the mineral water company (EULECO). These products are also subject to inport surcharges. 
48. There was some progress in the preparation of a preliminary poverty reduction strategy, but adoption of such a strategy (a structural benchmark for end-2001 under the program) is not expected until about mid-2002 (Box 9).

\section{Box 9. Poverty Reduction Strategy}

Following the Libreville Summit in early 2000 , the Gabonese authorities made a commitment to formulate and implement a poverty reduction strategy. They set up national interministerial and technical committees with representatives of concerned ministries and civil society. ${ }^{1}$ At end-2001, the authorities completed and presented to donors a preliminary document, which forms the basis for the preparation of a poverty reduction strategy. The document is based on several social studies and surveys completed or under preparation with assistance from the World Bank, the United Nations Development Program (UNDP), and several bilateral donors. ${ }^{2}$ It notes that, although Gabot made some progress in reducing poverty and improving social indicators in tecent years, income distribution remains highly unequal, poverty is widespread, and social indicators are weak (Table 9).

- Poverty incidence, defined as the share of the population with per capita consumption of less than twothirds of the national average, was estimated at about 62 percent (down from 68 percent in 1960) overall, and 85 percent in rural areas. ${ }^{3}$

- Primary school enrollment is well over 100 percent, but secondary school errollment is just over onehalf, and the completion rates for both school types are well below 50 percent, having deteriorated in recent years. This situation points to significant inefficiencies in the schooling system.

- Health indicators, such as life expectancy, infant and child mortality, and vaccination rates, have improved over the last few decades, but remain much worse than the averages for middle-income countries and close to those for low-income countries.

- The UNDP's human development index (HDI) ranked Gabon 118th cut of 174 (1999).

- The prevalence of HIV/AIDS was 6 percent in 1999, and over 8 percent in the two largest cities.

Following the recent discussions with donors and civil society, a revised version of the poverty reduction strategy document is under preparation (with UNDP support) and is expected to incorporate (i) a fuller definition of poverty; (ii) short- and medium-term social targets consistent with the objectives set out in Gabon's strategic "2015 Document;" (iii) integrated sectoral programs consistent with the short- and mediumterm objectives; and (iv) recommendations on budgetary provisions for social projects and their link to the public investment program.

${ }^{1}$ With the installation of the new government in January 2002, a new subministry was created with a Minister Delegate of State Control, Inspection, Fight Against Poverty and Fight Against Corruption, under the Prime Minister.

${ }^{2}$ These include (i) the demographic and health survey, published in August 2001 (a structural benchmark for end-June 2001); (ii) the school and health geographical distribution maps; and (iii) the study on unit costs in primary and secondary education (both of the latter two in progress).

${ }^{3}$ In 2001 , a threshold of two-thirds of average per capita consumption was equivalent to about US $\$ 3.5$ per person per day. 


\section{E. Medium-Term Outlook}

49. Dealing with the projected sharp decline in oil production and the heavy external debt-service burden remain Gabon's main challenges in the medium term. Despite increased efforts to exploit marginal oil fields (made possible by favorable oil prices in 2000-01), oil production is expected to decline rapidly, albeit at a slower speed than originally anticipated, falling from 13 million tons in 2001 to about 6 million tons in 2007. Based on the latest WEO oil price projections, oil revenue is expected to decline from CFAF 780 billion in 2001 (23 percent of GDP, and two-thirds of total government revenue) to about CFAF 200 billion in 2007 ( 6 percent of GDP, and less than one-fourth of total government revenue). Although Gabon's stock of external debt represents only some 60 percent of GDP, it consists essentially of nonconcessional loans with very short maturities, thereby putting extreme pressure on government finance in the medium term. As a result of declining oil revenue, scheduled external debt service-although falling in nominal terms-will continue to represent almost 40 percent of government revenue in the medium term (Table 7). Declining levels of oil revenue and the public investment required to facilitate non-oil economic activities point to the need for continued fiscal consolidation efforts to generate government savings. However, even with strong efforts, the government is likely to face significant financing gaps over the coming years. The staff projects non-oil growth at around 5 percent per year during 2002-07, driven by continued strong private investment and a moderate improvement in capital productivity. ${ }^{38}$ This level of investment and productivity will require (i) a substantial effort to mobilize non-oil private savings to mitigate the effect of larger tax collection and smaller transfers by the government; (ii) increased external financing, as shown by the widening savings-investment gap; and (iii) an improved economic environment for private enterprises. The fatter entails not only continued structural reforms, but also significant public investment in social and physical infrastructure.

50. Gabon's external and fiscal positions will continue to be sensitive to fluctuations in the production and price of oil (Table 8). Oil prices lower than current WEO projections by US\$1 in each year during 2002-07 would worsen the fiscal financing gap and the current account balance by about 1 percent of GDP on average per year. Similarly, a 10 percent lower oil production each year in 2002-07, compared to the baseline scenario, would cause the fiscal financing gap and the current account balance to deteriorate by about 1.5 percent of GDP on average per year. A 1 percentage point lower growth in non-oil exports over the 2002-07 period would worsen the current account by about 0.5 percent of GDP on average per year. By contrast, given the relatively low taxation of non-oil exports, the impact on government revenue and the fiscal financing gap would be negligible.

\footnotetext{
${ }^{38}$ Private non-oil investment is assumed to remain at about the level achieved in 2001 (about 19 percent of non-oil GDP, compared with an average of 14 percent during 1996-2000).
} 


\section{F. External Sector Policy Issues}

51. The current exchange arrangement and exchange rate level under the CFA monetary zone continue to be appropriate. The authorities emphasized that the exchange regime provided an anchor for financial stability and that developments in the real effective exchange rate of the CFA franc since the 1994 devaluation pointed to the maintenance of external competitiveness. They were of the view that Gabon's sustained fiscal consolidation would be a major contribution to the support of the peg to the euro. They were also confident that the deepening of structural reforms, particularly in the areas of governance, civil service reform and improvement in the regulatory framework, together with an adequate infrastructure for private sector activity, would help strengthen Gabon's external competitiveness.

52. Gabon's foreign trade system is relatively open and nearly free from quantitative restrictions (the only exception being sugar) ${ }^{39}$ The common external tariff (CET) under CEMAC has four tariff levels $\left(5,10,20\right.$, and 30 percent). ${ }^{40}$ Gabon is unable to respect fully its commitments vis-à-vis the World Trade Organization (WTO), as about 40 percent of its tariffs on nonagricultural products exceed the 15 percent agreed to in the context of the WTO. A study, financed by the European Union, is under way to analyze the fiscal impact in CEMAC countries of bringing the CET in line with commitments made under the WTO. Although under CEMAC rules surcharges should have been eliminated by mid-2000, Gabon currently applies 20 percent surcharges to 25 tariff lines, notably edible fats and oils, soap, poultry products, mineral water, cigarettes, and industrial lubricants. Taking surcharges into account, the unweighted average of Gabon's customs duties remained at about 18 percent in $2001 .^{41}$ On the Fund's index of trade restrictiveness, Gabon stood at 4 on a scale of 1 to 10 at end-2001, the same as in $2000 .^{42}$ The staff urged the authorities to eliminate the remaining surcharges and to continue their support within the CEMAC for further simplifying the CET and bringing it in line with WTO regulations.

53. The harmonization of exchange regulations within the CEMAC, adopted in April 2000, resulted in a decrease from CFAF 5 million to CFAF 1 million in the limit on foreign currency allowed to be purchased for foreign travel without supporting documentation.

${ }^{39}$ The quota on sugar will be eliminated at end-2003, as spelled out in the agreement between the government and the buyer of the then public sugar company in 1998.

${ }^{40}$ Discussions within the CEMAC are under way to merge the 20 percent and 30 percent rates into a single maximum tariff of 20 percent.

${ }^{41}$ A fee for the utilization of the customs information system (RUSID)-averaging about 2 percent of import value- is further added to the cost of the tariff.

${ }^{42}$ The overall index combines measurements of the restrictiveness of tariffs (Gabon had 4 on a scale of 1-5) and nontariff barriers (1 on a scale of 1-3). 
Although the regulations clearly spell out the requirements for obtaining larger amounts of foreign exchange, banks appear to have tended to interpret the rules rather strictly. The staff has advised that the commercial banks be notified about these requirements, so as to avoid unwarranted difficulties for travelers.

\section{G. Statistical Issues}

\section{The authorities, aware of the importance of good-quality statistical data for} economic management, are preparing a draft statistics law, expected to be completed in the second half of 2002. In November 2001, Gabon expressed the intention to participate in the GDDS; a national coordinator has been designated and draft metadata are being prepared. Significant weaknesses exist regarding the quality and timely production of balance of payments statistics. Annual balance of payments statistics are produced with a lag of about one year, and quarterly data are unavailable. Inadequate customs data, low response rates for surveys, and insufficient cooperation by-or coverage of - public administrations, embassies, and nongovernmental organizations (NGOs) contribute to the low quality of balance of payments statistics. The authorities intend to request further technical assistance from the Fund, while implementing the recommendations of the 1998 STA mission. ${ }^{43}$

\section{STaff Appraisal}

55. During 2001, the authorities continued with some success their efforts to improve public finances, regularize relations with Gabon's creditors, and reduce public debt. Economic policies under the government's program focused on fiscal consolidation, good governance, and improvement in the environment for private sector activity. Unfortunately, because of fiscal slippages and delays in implementing the structural reform agenda, many objectives of the government's program could not be attained as planned, and most of the reviews under the Stand-By Arrangement were not completed. Nevertheless, Gabon's overall fiscal consolidation and debt repayment efforts remained considerable, with primary surpluses averaging 17 percent of GDP in 2000-01 (double the average of the mid1990 s, before the 1998 financial crisis). This performance helped reduce total government debt substantially in the last two years.

56. Macroeconomic developments were favorable in 2001, with a pickup in growth of the non-oil sector, higher-than-expected oil production and prices, and improved private sector confidence. The primary fiscal surplus was very large, at 17 percent of GDP, but fell considerably short of the program target, and there were large, unbudgeted treasury outflows. The resulting expansion of net credit to government caused a significant deterioration in

\footnotetext{
${ }^{43}$ The main recommendations were to (i) improve cooperation between the BEAC and the macroeconomics, national accounts, and tax directorates of the Ministry of Finance; (ii) make better use of customs data; and (iii) seek agreement at the CEMAC level to increase the number of trained personnel.
} 
Gabon's net foreign assets position with the $\mathrm{BEAC}$, almost entirely reversing the gain made in 2000 .

57. The economic outlook for 2002 remains relatively good with a projected growth of non-0il GDP of about 6 percent. Beyond 2002, the prospects for growth and poverty reduction depend crucially on the extent to which the non-oil sector can replace the rapidly declining oil sector. Attaining this objective will require sustained fiscal consolidation and significant improvements in governance, the efficiency and equity of government spending, and the regulatory framework for private sector activity.

58. Fiscal program implementation in 2001 was below expectations. The excess of oil revenue above the program target was lower than expected, based on higher oil production and prices, and could have been saved in the Fund for Future Generations. Non-oil revenue remained just above its 2000 level, and efforts to improve tax administration did not yield the results desired. Because of delays in privatization, significant transfers to public enterprises were made, large unforeseen expenditures took place at year's end (partly incurred outside normal budget procedures), and domestic debt repayments were higher than programmed. This situation points to the need to strengthen expenditure control and enhance program monitoring.

59. For 2002 and beyond, continued strong fiscal consolidation efforts - and stronger commitment to fiscal reforms - will be crucial, and public spending will need to be more concentrated on building the social and physical infrastructure for non-oil private sector activities. However, with external debt service remaining high (almost 40 percent of revenue in each year during 2002-07), success will also depend on the possibility of achieving a somewhat less fast reduction in external debt by spreading the amortization obligations over a longer period.

60. The 2002 budget adopted last November, which foresaw a reduction in government savings and a sizable unfinanceable gap, was in the staff's view inappropriate. The staff welcomes the authorities' intention to prepare a revised 2002 budget, which would incorporate significant new revenue measures, a containment of nonpriority current spending, and a modest increase in investment expenditure, in line with ongoing improvements in the execution and monitoring capacity and the envisaged reorientation toward social and physical infrastructure. The authorities' intention to set aside in the Fund for Future Generations part of the budgeted oil revenue is also welcome. However, there is a need for stepped-up efforts to improve transparency in oil revenue, to ensure an adequate yield of the domestic petroleum and excise tax measures, and to strengthen customs and tax administration. In this regard, it is important to complete promptly the financial audits of the major foreign oil companies, to be followed by the implementation of their recommendations and, henceforth, annual audits; undertake regular tax audits of all large enterprises; and enhance transparency in the government's financial relations with enterprises. The collaboration of external partners in the government's efforts to increase transparency is essential. 
61. The staff notes the authorities' intention to contain the wage bill below the 2001 level and proceed with civil service reform in the course of 2002 , following the expected adoption by parliament of the related laws. It is important, however, that the new structures become effective as early as possible, so as to enhance the efficiency of the civil service and reduce the burden on the budget.

62. The intended reorientation of the investment budget toward infrastructure and social services is a positive step. However, investment projects need to be fully consistent with the objectives of reducing poverty and fostering private sector growth. In this context, the authorities are encouraged to promptly complete their interim poverty reduction strategy paper (PRSP), prepare the sectoral strategies consistent with the PRSP, and seek the technical and financial support of Gabon's partners.

63. The staff welcomes the progress made in 2001 in public expenditure management, in particular, the partial implementation of the integrated budget information system (CRYSTAL). However, it is regrettable that CRYSTAL did not cover most treasury accounts (including the so-called special funds, which are also not yet incorporated in the 2002 budget), and that delays were encountered in the introduction of a computerized personnel and payroll management system. The authorities should pursue vigorously these reforms, with external technical assistance where needed. Concerning the investment budget, the speedy introduction of the new procurement code and the envisaged strengthening of execution and monitoring procedures-building on the recent public investment reviewcould help achieve significant savings and improve effectiveness.

64. The discussions in parliament of the draft anticorruption laws and the authorities' efforts to ensure a fully independent Anticorruption Commission have been protracted. With the draft laws expected to be adopted shortly, the authorities should now focus on the their prompt implementation, including the effective establishment of the Anticorruption Conmission.

65. The delays in the privatization of public enterprises have represented a continued burden on the budget. This underlines the importance of adhering firmly to the new timetable for privatization and restructuring agreed with the World Bank staff, in particular with regard to the offer for sale of the telecommunications company. With regard to Air Gabon, the authorities' decision to seek a conversion of the frozen contract to purchase four new planes into lease contracts and their commitment to privatize the company are welcome. In the meantime, it would be important to accelerate the restructuring process and minimize the cost to the budget, and to adopt as soon as feasible a timetable for Air Gabon's privatization.

66. The ongoing or recently initiated reforms to enhance the environment for business are commendable but need to be fully implemented. Following the recent enactment of the forestry code, the reform of the forestry sector would need to be pursued with vigor, including through an overhaul of existing institutions, simplification of taxation, and the promotion of competition in export marketing. It is also important to adapt national 
laws (such as the commercial code) to the OHADA Uniform Acts, as well as to reform the judicial system. Finally, the authorities are encouraged to further liberalize economic activity by eliminating remaining import surcharges, removing price controls (except for a few basic goods), and simplifying business and trader licensing.

67. The staff welcomes the authorities' intention to further enhance the supervision of the financial sector, so as to strengthen its robustness against macroeconomic and sectoral risks, taking into account the recommendations of the recent joint World Bank/Fund Financial System Stability Assessment. Regarding the National Social Security Fund (CNSS), the recent steps to address serious financial and organizational problems are encouraging. These steps would pave the way for a restructuring of the system (including the consolidation of government debt owed to the CNSS), so as to ensure its long-term financial soundness, while enabling its obligations to all enrollees to be met in the meantime.

68. The provision of data for surveillance and program monitoring, though significantly improved since 1999 , remains relatively weak. The new integrated budget information system should help improve the quality and timeliness of fiscal data. Addressing weaknesses in balance of payments and national accounts statistics (notably the oil sector) should be assigned a high priority. More generally, montbly reporting on program implementation and monitoring needs to be significantly strengthened, including through a greater mandate and capacity of the interministerial technical program monitoring committee. The staff welcomes Gabon's recent decision to participate in the GDDS and encourages the authorities to promptly adapt its statistics system and produce metadata in accordance with GDDS standards.

69. Desplte underimplementation of the fiscal and structural reform program supported by the 18-month Stand-By Arrangement, Gabon's underlying efforts during the last few years to put public finances on a sound footing and regularize relations with its creditors represent a significant achievement, in particular, in view of the very heavy debt-service burden. The authorities are encouraged to regain the momentum of fiscal and structural reforms (for which the agenda remains large). This could be demonstrated by the prompt adoption of a revised 2002 budget that is consistent with the government's objectives of fiscal sustainability and poverty reduction, as well as by the implementation of key structural measures, which had been delayed, in particular in the governance area. Prompt and decisive actions in these areas could lay the basis for discussions on a new medium-term program, which could obtain the support of the international community.

70. It is proposed that the next Article IV consultation with Gabon be held on the standard 12-month cycle. 
Figure 1. Gabon: Government Fiscal Operations, 1993-2002
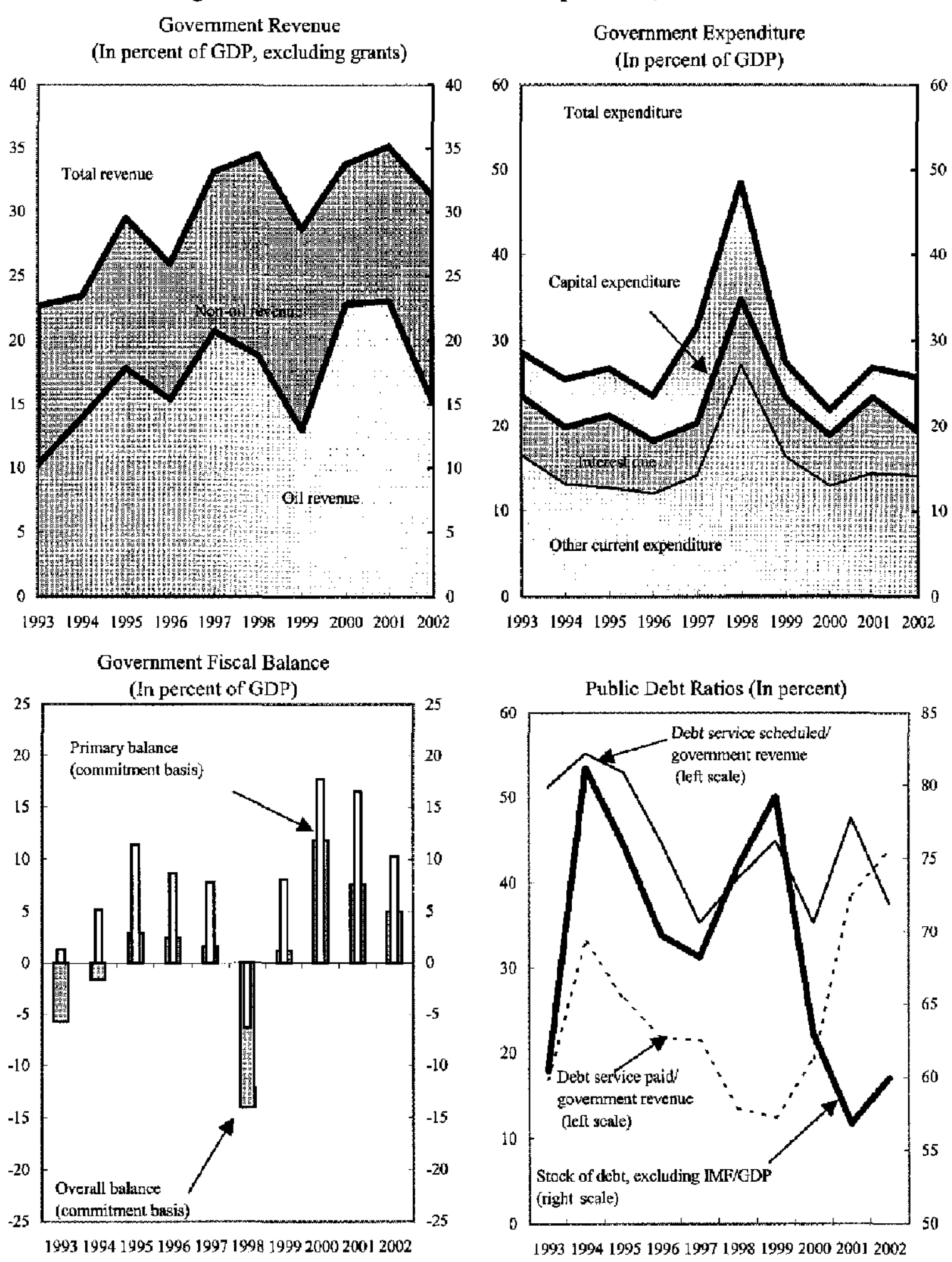

Sources: Gabonese authorities; and staff estimates and projections. 
Figure 2. Gabon: Selected Real and External Sector Indicators, 1993-2002

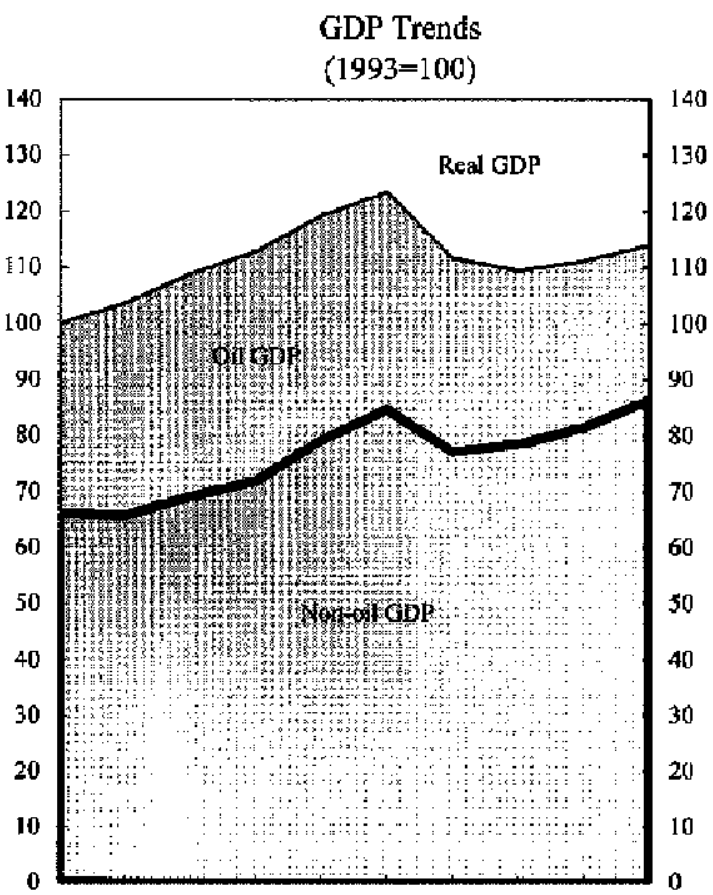

$1993 \quad 1994 \quad 19951996199719981999200020012002$

Export and Import Volumes

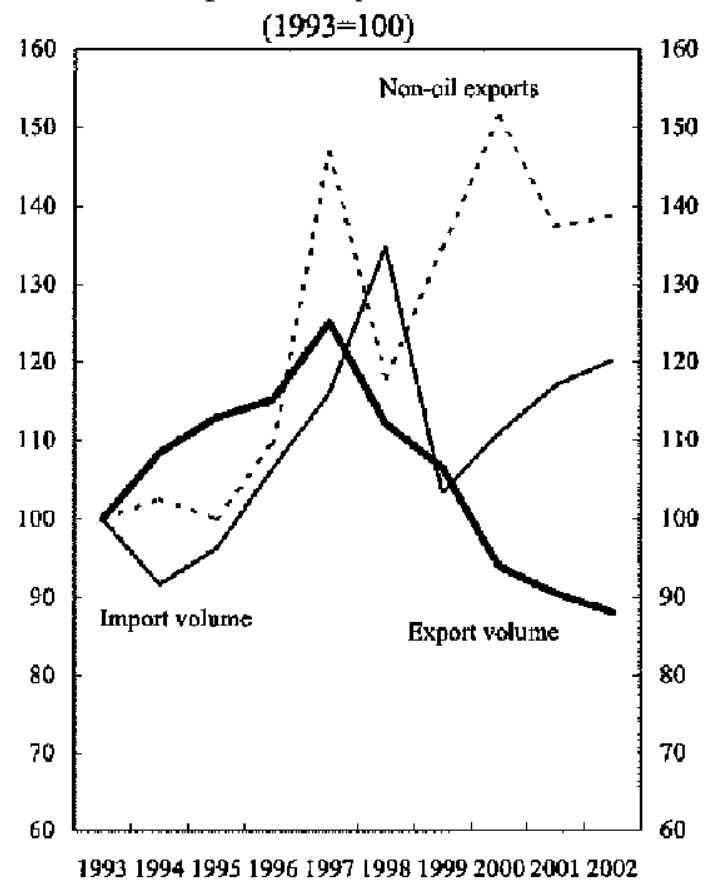

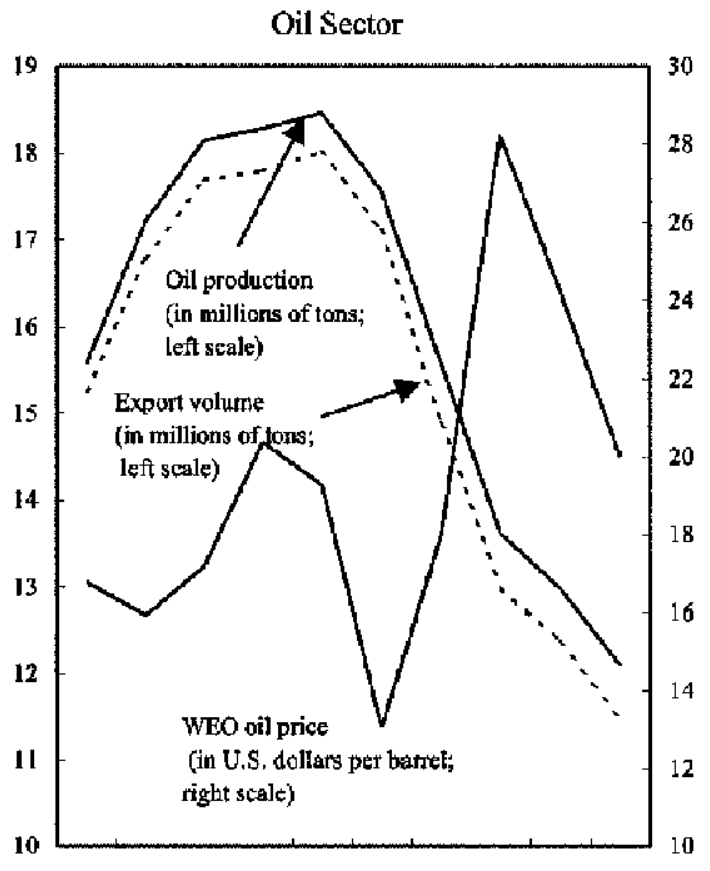

1993199419951996199719981999200020012002

External Sector Balance

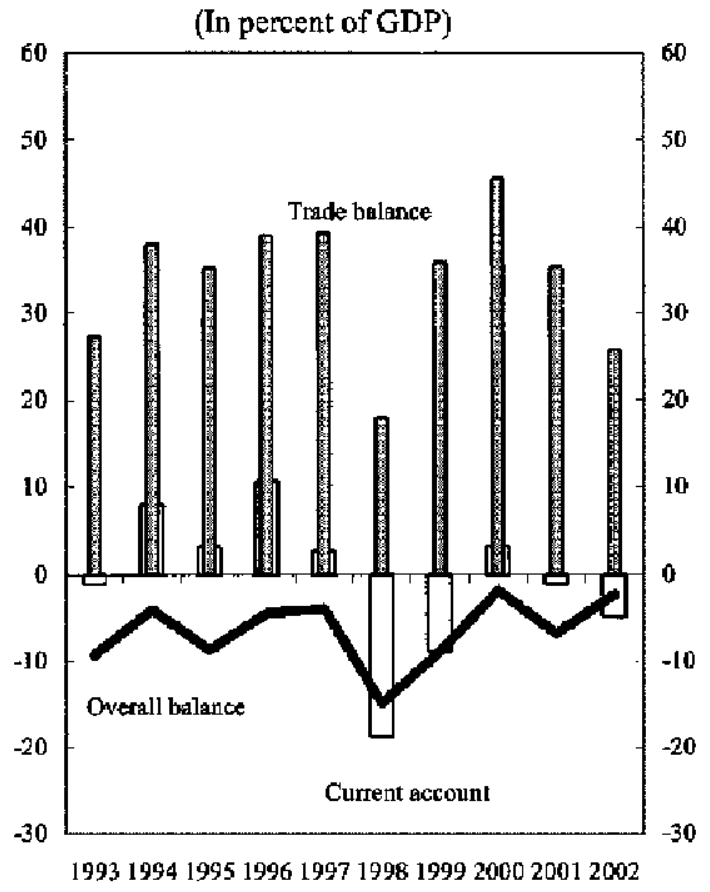

Sources: Gabonese authorities; and staff estimates and projections. 
Figure 3. Gabon: Nominal and Real Effective Exchanges Rates, January 1993-November 2001

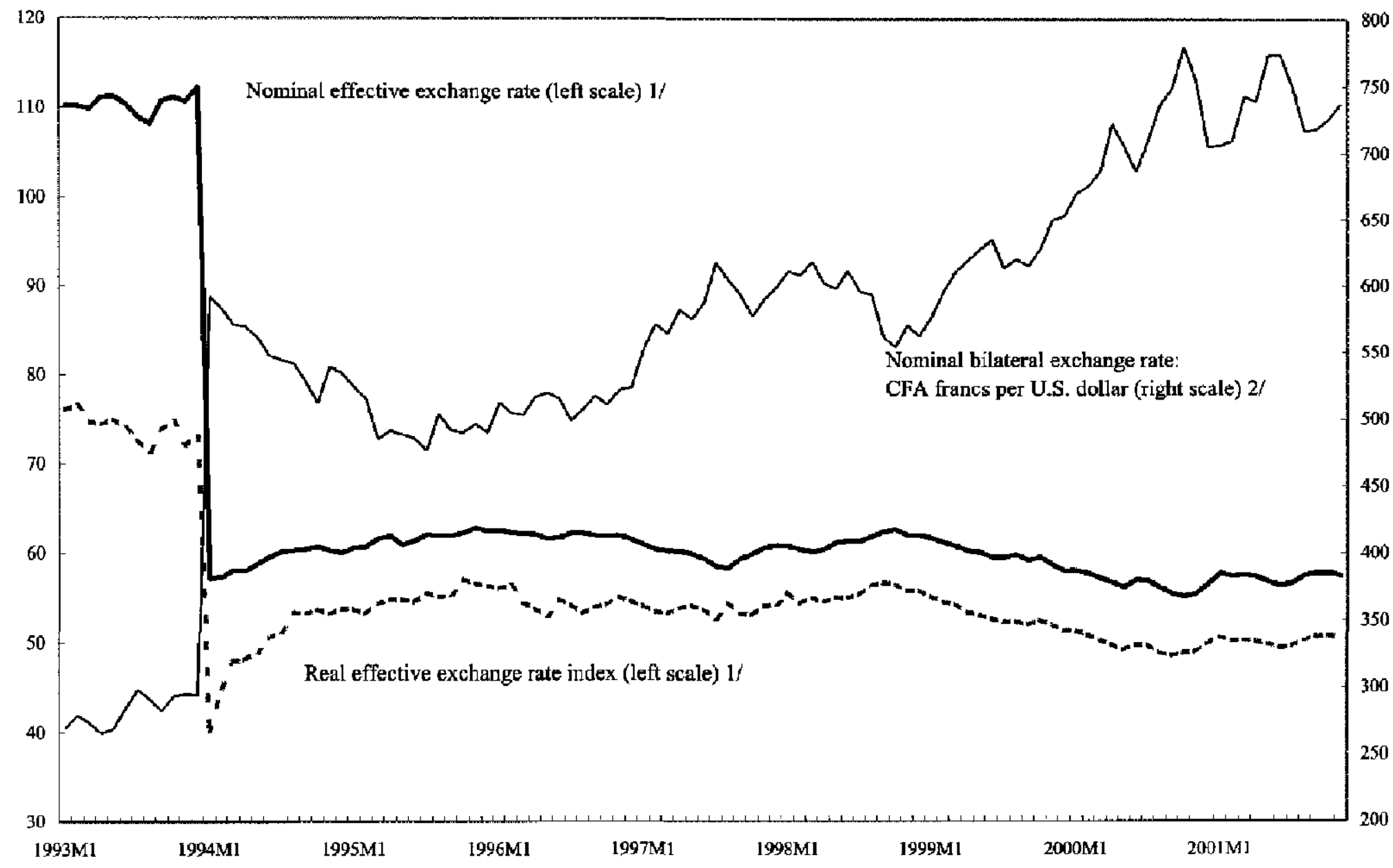

Sources: IMF, International Financial Statistics (IFS) ; Itformation Notice System (INS); and World Economic Outlook (WEO) .

$1 /$ Index $1990=100$. A decrease means a depreciation of the CFA franc.

2/ End-of-period exchange rate on a monthly basis. A decrease means an appreciation of the CFA franc. 
Table 1. Gabon: Selected Economic Indicators, 1998-2007

\begin{tabular}{|c|c|c|c|c|c|c|c|c|c|c|c|c|}
\hline & \multirow[t]{2}{*}{1998} & \multirow[t]{2}{*}{1999} & \multirow[t]{2}{*}{2000} & \multicolumn{2}{|c|}{2001} & \multicolumn{2}{|l|}{2002} & \multirow[t]{2}{*}{2003} & 2004 & 2005 & \multirow[t]{2}{*}{2006} & \multirow[t]{2}{*}{2007} \\
\hline & & & & $\begin{array}{l}\text { Prog. } \\
\text { S/01/56 }\end{array}$ & $\begin{array}{l}\text { Prel. } \\
\text { est. }\end{array}$ & $\begin{array}{r}\text { Prog. } \\
\text { EBS } / 01 / 56\end{array}$ & Proj. & & & jections & & \\
\hline & \multicolumn{12}{|c|}{ (Annual percent change) } \\
\hline \multicolumn{13}{|l|}{ Production and prices } \\
\hline GDP at constant prices & 3.5 & -9.6 & -1.9 & -1.6 & 1.5 & -0.6 & 2.5 & -0.3 & 0.8 & 2.0 & 2.4 & 2.7 \\
\hline Oil & -3.4 & -11.1 & -10.0 & -14.8 & -4.6 & -12.6 & -6.8 & -14.2 & -13.5 & -12.2 & -12.7 & -12.2 \\
\hline Non-oil & 7.0 & -8.9 & 1.7 & 3.6 & 3.9 & 3.2 & 5.9 & 4.2 & 4.6 & 5.1 & 5.1 & 4.9 \\
\hline GDP at current prices & -14.9 & 7.4 & 26.0 & -14.2 & -5.3 & -4.9 & -6.8 & -1.9 & 0.1 & 1.4 & 1.5 & 2.6 \\
\hline GDP deflator & -17.8 & 18.7 & 28.4 & -12.8 & -6.7 & -4.3 & -9.1 & -1.7 & -0.7 & -0.6 & -0.9 & -0.1 \\
\hline Oil & -40.5 & 61.6 & 80.7 & $\ldots$ & -12.5 & $\ldots$ & -19.9 & -0.8 & -0.1 & -0.6 & -3.3 & -0.6 \\
\hline Non-oil & -2.2 & 2.3 & 2.2 & $\ldots$ & 1.3 & $\ldots$ & 1.3 & 0.1 & 1.3 & 1.4 & 1.0 & 1.1 \\
\hline \multicolumn{13}{|l|}{ Consumer prices } \\
\hline Yearly average & 2.3 & -0.7 & 0.4 & 2.0 & 2.1 & 2.0 & 2.0 & 2,0 & 2.0 & 2.0 & 2.0 & 2.0 \\
\hline End of period & 2.6 & -0.8 & 1.8 & 2.0 & 1.0 & 2.0 & 2.0 & 2.0 & 2.0 & 2.0 & 2.0 & 2.0 \\
\hline \multicolumn{13}{|l|}{ External sector } \\
\hline Exports, fo.b. (CFA francs) & -37.2 & 36.9 & 48.4 & -26.5 & -15.6 & -10.9 & -18.7 & -9.9 & -8.2 & -6.7 & -7.4 & -4.6 \\
\hline Of which: oil & -40.6 & 37.2 & 59.9 & -34.2 & -17.4 & -19.1 & -25.2 & -15.3 & -14.1 & -13.3 & -16.1 & -13.4 \\
\hline Inxports, f.o.b. (CFA francs) & 14.9 & -19.9 & 26.2 & 13.2 & 11.2 & 11.6 & 3.4 & -2.5 & -1.0 & -1.6 & -0.7 & -3.4 \\
\hline Export volume & -10.4 & -5.0 & -11.8 & -10.5 & -3.6 & -5.3 & -2.7 & -9.6 & -8.2 & -6.4 & -5.0 & -4.3 \\
\hline Import volume & 16.2 & -23.4 & 7.3 & 12.6 & 5.5 & 9.2 & 2.7 & -3.3 & -2.1 & -2.9 & -2.1 & -3.4 \\
\hline Terms of trade (-=deterioration $)$ & -29.0 & 37.9 & 43.0 & -18.4 & -16.9 & -8.0 & -17.0 & $-1,3$ & -1.1 & -1.7 & -3.9 & -0.3 \\
\hline \multicolumn{13}{|l|}{ Nominal effective exchange rate } \\
\hline (period average; - = depreciation) & 2.5 & -2.5 & -5.5 & $\ldots$ & 1.4 & $\ldots$ & $\ldots$ & $\ldots$ & $\ldots$ & $\ldots$ & $\ldots$ & $\ldots$ \\
\hline \multicolumn{13}{|l|}{ Real effective exchange rate } \\
\hline (period average; $-=$ depreciation) & 3.4 & -4.4 & -6.9 & $\cdots$ & 1.7 & $\ldots$ & $\cdots$ & $\ldots$ & $\cdots$ & $\ldots$ & $\cdots$ & $\cdots$ \\
\hline \multicolumn{13}{|l|}{ Central government finance } \\
\hline Total revenue & -11.4 & -10.8 & 48.4 & 2.3 & -1.4 & -25.0 & -17.1 & -5.0 & -3.9 & -1.7 & -3.6 & -1.7 \\
\hline Oil revenue & -22.6 & -26.0 & 121.0 & -6.7 & -4.1 & .43 .3 & -38.8 & -13.5 & -15.9 & -12.5 & -21.3 & -16.4 \\
\hline Non-oil revenue & 7.2 & 7.5 & -11.7 & 20.9 & 4.1 & 4.4 & 24.4 & 3.0 & 5.6 & 5.1 & 5.7 & 4.0 \\
\hline Total expenditure & 30.7 & -39.2 & 0.8 & 15.4 & 18.8 & -17.3 & -11.0 & -9.8 & -4.1 & -2.5 & -2.0 & -0.2 \\
\hline Current & 45.7 & -28.1 & 2.1 & 15.9 & 17.2 & -21.0 & -22.6 & -6.2 & -5.5 & -5.2 & -4.2 & -0.9 \\
\hline \multirow[t]{2}{*}{ Capital } & 3.8 & -67.2 & -11.6 & 19.1 & 12.6 & 8.2 & 69.1 & -12.0 & 0.6 & 5.6 & 4.1 & 1.4 \\
\hline & \multicolumn{12}{|c|}{ (In percent of beginning-of-period broad money, unless otherwise indicated) } \\
\hline \multicolumn{13}{|l|}{ Money and credit } \\
\hline Net domestic assets & 29.5 & -3.2 & -31.5 & 7.0 & 42.6 & $\ldots$ & -0.1 & $\ldots$ & $\ldots$ & $\ldots$ & $\ldots$ & $\ldots$ \\
\hline Domestic credit & 27.5 & -5.6 & -33.7 & 6.4 & 38.8 & $\ldots$ & -0.1 & $\ldots$ & $\ldots$ & $\cdots$ & $\cdots$ & $\cdots$ \\
\hline Central government & 26.1 & -5.3 & -39.3 & 0.0 & 27.4 & $\ldots$ & -10.1 & $\ldots$ & $\ldots$ & $\ldots$ & $\ldots$ & $\ldots$ \\
\hline Credit to the economy & 2.3 & 0.7 & 8.3 & 7.1 & 11.8 & $\ldots$ & 10.0 & $\ldots$ & $\ldots$ & $\cdots$ & $\ldots$ & $\ldots$ \\
\hline (annual percentage change) & 3.5 & 1.0 & 11.7 & 10.5 & 17.4 & $\ldots$ & 13.5 & $\cdots$ & $\ldots$ & $\cdots$ & $\ldots$ & $\ldots$ \\
\hline Broad money & -1.8 & -2.7 & 18.0 & 1.9 & 7.5 & 1.6 & 4.9 & $\ldots$ & $\ldots$ & $\ldots$ & $\ldots$ & $\cdots$ \\
\hline \multicolumn{13}{|l|}{ Velocity of broad money } \\
\hline (non-oil GDP, end of period) & 4.1 & 4.0 & 3.5 & 3.7 & 3.4 & 3.8 & 3.5 & $\ldots$ & $\ldots$ & $\ldots$ & $\cdots$ & $\ldots$ \\
\hline
\end{tabular}


Table 1. Gabon: Selected Economic Indicators, 1998-2007

\begin{tabular}{|c|c|c|c|c|c|c|c|c|c|c|c|c|}
\hline & \multirow[t]{2}{*}{1998} & \multirow[t]{2}{*}{1999} & \multirow[t]{2}{*}{2000} & \multicolumn{2}{|c|}{2001} & \multicolumn{2}{|l|}{2002} & \multirow[t]{2}{*}{2003} & 2004 & 2005 & \multirow{2}{*}{2005} & \multirow[t]{2}{*}{2007} \\
\hline & & & & $\begin{array}{l}\text { Prog. } \\
101 / 56\end{array}$ & $\begin{array}{r}\text { Prel. } \\
\text { est. }\end{array}$ & $\begin{array}{r}\text { Prog. } \\
\text { EBS } / 01 / 56\end{array}$ & Proj. & & & ojections & & \\
\hline & \multicolumn{12}{|c|}{ (In percent of GDP, unless otherwise indicated) } \\
\hline Gross national savings & 20.4 & 15.4 & 25.3 & 27.8 & 23.8 & 28.4 & 23.9 & 23.6 & 22.4 & 22.6 & 21.5 & 21.4 \\
\hline Government & -0.3 & 5.4 & 14.7 & 14.6 & 11.0 & 10.6 & 11.3 & 11.7 & 11.6 & 11.8 & 11.3 & 10.7 \\
\hline Private sector & 20.6 & 10.0 & 10.6 & 13,2 & 12.8 & 17.9 & 12.6 & 11.8 & 10.9 & 10.8 & 10.2 & 10.7 \\
\hline Gross domestic savings & 38.5 & 45.0 & 53.8 & 50.1 & 46.4 & 44.6 & 41.4 & 38.8 & 36.4 & 35.0 & 32.8 & 31.7 \\
\hline Government & 6.6 & 11.5 & 19.9 & 24.2 & 19.0 & 15.9 & 15.7 & 15.5 & 14.9 & 14.7 & 13.8 & 12.8 \\
\hline Private sector & 31.9 & 33.5 & 33.9 & 25.9 & 27.3 & 28.7 & 25.6 & 23.3 & 21.5 & 20.3 & 19.0 & 19.0 \\
\hline Gross fixed investment & 39.1 & 24.2 & 22.1 & 27.3 & 24.9 & 28.8 & 28.7 & 28.7 & 28.5 & 28.2 & 27.6 & 26.5 \\
\hline Government & 13.7 & 4.2 & 2.9 & 4.0 & 3.5 & 4.6 & 6.3 & 5.7 & 5.7 & 5.9 & 6.1 & 6.0 \\
\hline Private sector & 25.4 & 20.0 & 19.2 & 23.2 & 21.4 & 24.2 & 22.4 & 23.0 & 22.8 & 22.2 & 21.5 & 20.5 \\
\hline \multicolumn{13}{|l|}{ Nominal GDP (in billions of } \\
\hline CFA francs) & 2,645 & 2,840 & 3,577 & 3,098 & 3,387 & 2,948 & 3,157 & 3,096 & 3,099 & 3,143 & 3,189 & 3,272 \\
\hline \multicolumn{13}{|l|}{ Central government } \\
\hline \multicolumn{13}{|l|}{ Primary budget balance } \\
\hline (commitment basis) & -6.3 & 8.1 & 17.7 & 21.1 & 16.5 & 12.0 & 10.2 & 10.7 & 10.3 & 9.9 & 8.8 & 8.0 \\
\hline Overall balance (commitment basis) & -14.0 & 1.2 & 11.8 & 10.6 & 7.6 & 6.0 & 5.0 & 6.5 & 5.8 & 5.9 & 5.2 & 4.7 \\
\hline Overall balance (cash basis) & -10.9 & 1.3 & 4.1 & 8.9 & 6.3 & 6.0 & 4.1 & 5.1 & 5.8 & 5.9 & 5.2 & 4.7 \\
\hline Domestic bank financing & 4.6 & -0.9 & -4.9 & 0.0 & 4.3 & -1.4 & -1.8 & -2.3 & -2.3 & -2.1 & -1.5 & -1.2 \\
\hline \multicolumn{13}{|l|}{ Net external financing (including } \\
\hline obtained debt relief) & -0.5 & -0.2 & 4.5 & -7.7 & -6.2 & -4.3 & -6.3 & -5.2 & -5.6 & -5.3 & -5.1 & -5.0 \\
\hline Financing gap & 0.0 & 0.0 & 0.0 & 0.0 & 0.0 & 1.5 & 6.0 & 3.1 & 2.6 & 2.1 & 2.0 & 2.1 \\
\hline \multicolumn{12}{|l|}{ External current account balance } & -5.1 \\
\hline \multicolumn{11}{|l|}{ External debt service paid/government } & 38.1 & 37.5 \\
\hline \multicolumn{13}{|l|}{ External public debt (including gap } \\
\hline financing, excluding the Fund) & 75.5 & 79.2 & 62.9 & 60.2 & 56.8 & 59.7 & 59.9 & 59.3 & 56.4 & 52.6 & 48.9 & 45.0 \\
\hline \multicolumn{13}{|l|}{ Net transfer of resources to } \\
\hline the government 2 / & -4.2 & -3.2 & -6.1 & -17.7 & -13.7 & -10.0 & -12.1 & -9.6 & -10.0 & -9.3 & -8.5 & -7.9 \\
\hline
\end{tabular}

Sources: Gabonese authorities; and Fund staff estimates and projections.

1/ Including the Fund.

2/ Defined as net external inflows to the government over GDP, excluding gap financing. 
Table 2. Gabon: Fiscal Operations of the Central Government, 2000-02 1/

(In billons of CFA francs, unless otherwise indicated)

\begin{tabular}{|c|c|c|c|c|c|c|c|c|c|c|c|}
\hline & \multirow{3}{*}{$\begin{array}{r}2000 \\
\text { Est. }\end{array}$} & \multirow{2}{*}{\multicolumn{2}{|c|}{$\begin{array}{l}2001 \\
\text { June }\end{array}$}} & \multicolumn{5}{|c|}{2001} & \multirow{2}{*}{\multicolumn{3}{|c|}{$\frac{2002}{\text { Budget }}$}} \\
\hline & & & & \multicolumn{2}{|c|}{ Sep. } & \multicolumn{3}{|c|}{ Dew. } & & & \\
\hline & & $\begin{array}{l}\text { Sup. } \\
\text { LOI }\end{array}$ & $\overline{\text { Est. }}$ & Prog. & Est. & Prog. & $\begin{array}{l}\text { Prel. } \\
\text { est. }\end{array}$ & $\begin{array}{l}\text { Est.- } \\
\text { Prog. }\end{array}$ & $\begin{array}{r}\text { Prog. } \\
\text { EBS/01/56 }\end{array}$ & $\begin{array}{l}\text { Budget } \\
\text { Law } 2002\end{array}$ & $\begin{array}{l}\text { Staff } \\
\text { prop. }\end{array}$ \\
\hline Total revenue and grants & $1,207.6$ & 699.4 & 640.5 & 953.1 & 927.9 & $1,235.1$ & $1,190.1$ & -45.0 & 926.4 & $1,041.7$ & 988.5 \\
\hline Revenue & $1,207.6$ & 699.4 & 640.5 & 953.1 & 927.9 & $1,235.1$ & $1,190.1$ & 45.0 & 926.4 & $1,039.8$ & 986.6 \\
\hline Oil revenue & 814.7 & 479.2 & 439.3 & 613.2 & 623.4 & 760.1 & 781.4 & 21.2 & 430.8 & 510.0 & 478.1 \\
\hline Non-oil revenue & 392.9 & 220.2 & 201.2 & 339.9 & 304.5 & 475.0 & 408.8 & -66.2 & 495.7 & 529.8 & 508.5 \\
\hline Direct taxes & 81.9 & 57.8 & 55.4 & 63.3 & 79.9 & 89.3 & 99.0 & 9.7 & 93.7 & 150.6 & 120.0 \\
\hline Indirect taxes & 80.2 & 34.4 & 36.1 & 62.8 & 519 & 90.4 & 70.7 & -19.7 & 94.4 & 89.9 & 98.0 \\
\hline Taxes on intemational trade & 214.7 & 113.1 & 101.5 & 195.6 & 153.8 & 268.2 & 211.0 & .57 .2 & 281.5 & 265.0 & 255.5 \\
\hline bnport taxes & 186.7 & 89.0 & 86.4 & $\ldots$ & 134.5 & 230.3 & 184.1 & .46 .2 & 239.3 & 225.3 & 220.0 \\
\hline Export taxes & 28.0 & 24.1 & 15.1 & $\ldots$ & 19.3 & 37.9 & 26.9 & -11.0 & 42.2 & 39.8 & 35.5 \\
\hline Other revenue & 16.1 & 15.0 & 8.3 & 18.2 & 18.8 & 27.1 & 28.2 & 1.1 & 26.1 & 24.2 & 35.0 \\
\hline Foreign grants & 0.0 & 0.0 & 0.0 & 0.0 & 0.0 & 0.0 & 0.0 & 0.0 & 0.0 & 1.9 & 1.9 \\
\hline Total expenditure and net 1 & 786.1 & 457.5 & 459.5 & 700.8 & 712,9 & 907.1 & 934.2 & 27.1 & 750.2 & 913.3 & 831.8 \\
\hline Total expendihure, exchuding inte & 574.1 & 284.5 & 297.2 & 429.1 & 460.2 & 580.1 & 631.5 & 51.4 & 572.9 & 742.4 & 666.1 \\
\hline Current expenditure & 674.8 & 403.2 & 390.0 & 613,3 & 613.5 & 782.0 & 790.9 & B.8 & 618.0 & 675.5 & 611.8 \\
\hline Wages and salaries & 216.6 & 111.1 & 106.6 & 164.5 & 159.9 & 2179 & 213.4 & 4.5 & 213.9 & 217.9 & 196.0 \\
\hline Purchases of goods & 128.3 & 66.8 & 69.7 & 100.2 & 112.0 & 133.6 & 135.5 & 1.9 & 131.3 & 141.3 & 130.0 \\
\hline Transfers and subsi & 117.8 & 52.3 & 51.4 & 76.8 & 88.9 & 103.5 & 139.2 & 35.7 & 95.5 & 145.4 & 120.0 \\
\hline Interest payments & 212.0 & 173.0 & 162.3 & 271.8 & 252.7 & 327.0 & 302.8 & -24.3 & 177.3 & 170.9 & 165.8 \\
\hline Domestic & 27.8 & 16.6 & 15.2 & 26.6 & 23.3 & 33.1 & 34.6 & 1.5 & 22.5 & 23.3 & 23.3 \\
\hline Extemal 2f & 184.2 & 156.5 & 147.1 & 245.2 & 229.4 & 293.9 & 268.2 & -25.8 & 154.8 & 147.6 & 142.4 \\
\hline Capital expenditure & 105.1 & 37.5 & 51.6 & 87.6 & 80.4 & 125.1 & 118.3 & -6.8 & 1353 & 231.8 & 200.0 \\
\hline Net lending (including equity participation) $3 /$ & 6.2 & 16.8 & 17.9 & 0.0 & 19.1 & 0.0 & 25.1 & 25.1 & -3.1 & 6.0 & 20.0 \\
\hline Overall balance (on a commitment basis) & 421.5 & 241.9 & 181.0 & 252.3 & 214.9 & 328.0 & 255.9 & -72.1 & 176.3 & 128.3 & 156.7 \\
\hline Primary balance ? & 13.5 & 414.9 & 343.3 & 524.1 & 467.6 & 655.0 & 558.7 & -96.3 & 353.6 & 299.3 & 322.5 \\
\hline Change in payments arrears & -276.1 & -12.9 & -55.6 & -17.1 & -26.8 & -51.8 & 42.0 & 9.8 & 0.0 & -25.5 & -28.9 \\
\hline Extenal $2 / 4$ & -201.3 & 0.0 & 20.4 & 0.0 & 42.3 & 0,0 & 28.9 & 28.9 & 0.0 & 0.0 & -28.9 \\
\hline Domestic & .74 .9 & .12 .9 & .76 .1 & $-17,1$ & -69.1 & -51.8 & -70.9 & .19 .1 & 0.0 & -25.5 & 0.0 \\
\hline Arrears on interest on domestic debt & -0.9 & 0.0 & 1.3 & 0.0 & 2.5 & 0.0 & 2.3 & 2.3 & 0.0 & 0.0 & 0.0 \\
\hline lers at the treasury) & -45.9 & -11.7 & -52.7 & -15.8 & -61.9 & -50.1 & -4.7 & 2.4 & 0.0 & -25.5 & 0.0 \\
\hline Other floa & -16.5 & 0.0 & -23.5 & 0.0 & -8.5 & 0.0 & -24.3 & -24.3 & 0.0 & 0.0 & 0.0 \\
\hline Compensation for political violence & -11.6 & -1.2 & -1.2 & -1.3 & -1.2 & -1.7 & -1.2 & 0.5 & 0.0 & 0.0 & 0.0 \\
\hline Overall balance (on a cash basis) & 145.4 & 229.0 & 125.4 & 235.2 & 188.2 & 276.2 & 214.0 & $-62,3$ & 176.3 & 102.8 & 127.8 \\
\hline Financing & -145.4 & -229.0 & -125.4 & -235.2 & -188.2 & -276.2 & -214.0 & 62.3 & -219.1 & -387.5 & -318.0 \\
\hline Extemul (ne & 160.2 & -149.7 & -138.6 & -210.0 & -176.8 & -238.1 & -209.2 & 28.9 & -126.9 & -198.3 & -199.0 \\
\hline Drawings & 22.7 & 5.0 & 5.1 & 15.0 & 5.1 & 20.0 & 5.1 & .14 .9 & 25.0 & 25.0 & 65.0 \\
\hline Project firancing & 22.7 & 5.0 & 5.1 & 15.0 & 5.5 & 20.0 & 5.1 & -14.9 & 25.0 & 25.0 & 65.0 \\
\hline Program financing & 0.0 & 0.0 & 0.0 & 0.0 & 0.0 & 0.0 & 0.0 & 0.0 & 0.0 & 0.0 & 0.0 \\
\hline Amortization $2 /$ & -242.1 & -169.1 & -164.6 & -243.6 & -253.8 & -281.0 & -297.7 & -16.6 & -168.9 & -240.3 & $-233,0$ \\
\hline Arrears (reduction -) 2/4/ & -271.6 & 0.0 & 6.6 & 0.0 & 53.3 & 0.0 & 31.0 & 31.0 & 0.0 & 0.0 & -31.0 \\
\hline Foreign exchange effect on & & & & & & & & & & & \\
\hline extemal debt payments & -9.3 & 0.0 & 0.0 & 0.0 & 0.0 & 0.0 & 0.0 & 0.0 & 0.0 & 0.0 & 0.0 \\
\hline Debt rescheduling & 649.5 & 0.0 & 0.0 & 0.0 & 0.0 & 0.0 & 29.4 & 29.4 & 0.0 & 0.0 & 0.0 \\
\hline Debt cancellation & 17.0 & 8.5 & 8.5 & 12.8 & 12.8 & 17.0 & 17.0 & 0.0 & 17.0 & 17.0 & 0.0 \\
\hline Advance extemal debt payments & -5.9 & 5.9 & 5.9 & 5.9 & 5.9 & 5.9 & 5.9 & 0.0 & 0.0 & 0.0 & 0.0 \\
\hline
\end{tabular}


Table 2. Gabon: Fiscal Operations of the Central Government, 2000-02 1/

(In billions of CFA francs, unless otherwise indicated)

\begin{tabular}{|c|c|c|c|c|c|c|c|c|c|c|c|}
\hline & \multirow{3}{*}{$\begin{array}{r}2000 \\
\text { Est. }\end{array}$} & \multirow{2}{*}{\multicolumn{2}{|c|}{$\begin{array}{l}2001 \\
\text { June }\end{array}$}} & \multicolumn{5}{|c|}{2001} & \multicolumn{3}{|c|}{2002} \\
\hline & & & & \multicolumn{2}{|c|}{ Sep. } & \multicolumn{3}{|c|}{ Dec. } & \multicolumn{3}{|c|}{ Budget } \\
\hline & & $\begin{array}{l}\text { Sup. } \\
\text { LOI }\end{array}$ & $\overline{\text { Est. }}$ & Prog. & Est. & Prog & $\begin{array}{r}\text { Prel. } \\
\text { est. }\end{array}$ & $\begin{array}{l}\text { Est- } \\
\text { Prog. }\end{array}$ & $\begin{array}{r}\text { Prog. } \\
\text { EBS } / 01 / 56\end{array}$ & $\begin{array}{l}\text { Budget } \\
\text { Law } 2002\end{array}$ & $\begin{array}{l}\text { Staff } \\
\text { prop. }\end{array}$ \\
\hline Domestic (net) & -305.7 & -79.3 & 13.1 & -252 & -11.4 & -38.2 & -4.7 & 33.4 & -92.2 & -189.2 & -119.0 \\
\hline Banking system & -175.4 & -23.4 & 58.9 & 11.2 & 121.7 & 0.2 & 144.7 & 144.5 & -41.1 & -48.0 & -57.1 \\
\hline Bank of Central African States (BEAC) & -59.9 & -15.9 & 44.0 & 22.6 & 103.8 & 15.3 & 109.5 & 94.2 & -26.1 & -39.6 & -57.1 \\
\hline Of which: Fund for Future Generations & 0.0 & 0.0 & 0.0 & 0.0 & 0.0 & 0.0 & 0.0 & 0.0 & 0.0 & 0.0 & -47.8 \\
\hline Commercial banks & -115.5 & -7.6 & 14.9 & -11.3 & 17.9 & -15.1 & 35.2 & 503 & -150 & -8.4 & 0.0 \\
\hline Nonbank sources & -130.3 & -55.9 & -45.7 & -36.5 & -133.1 & -38.4 & -149.4 & -111.1 & -51.1 & -141.2 & -61.9 \\
\hline Domestic debt & -115.0 & -50.8 & 40.4 & -39.3 & -68.0 & -40.7 & -82.1 & -41.4 & -36.1 & -51.9 & -37.2 \\
\hline Oil company advanoes (net) & -36.4 & 0.0 & 0.0 & 0.0 & 0.0 & 0.0 & 0.0 & 0.0 & 0.0 & 0.0 & 0.0 \\
\hline Debt DGCP & -72.1 & -46.8 & -35.8 & -36.3 & -61.9 & -35.7 & -74.2 & -38.5 & -36.1 & 46.9 & -32.2 \\
\hline Securitized commencial agreements & -62.9 & -43.5 & -33.4 & -31.4 & -58.1 & -30.8 & -68.3 & -37.5 & -36.1 & -46.9 & -32.2 \\
\hline Of which: advance payments & 0.0 & 0.0 & -10.0 & 0.0 & -10.0 & 0.0 & -10.0 & $-10,0$ & 0.0 & 0.0 & 0.0 \\
\hline Other (divers) 6 & -9.1 & -3.3 & -2.4 & -4.9 & -3.8 & -4.8 & -5.9 & $-1,1$ & 0.0 & 0.0 & 0.0 \\
\hline \multicolumn{12}{|l|}{ Regularization of civil servants' salaries } \\
\hline (rappels) 7 & -6.5 & -4.0 & 4.6 & -3.0 & -6.1 & -5.0 & -7.9 & -2.9 & 0.0 & -5.0 & -5.0 \\
\hline \multicolumn{12}{|l|}{ Change in domestic arrears (on principal, } \\
\hline -reduction) & -2.0 & 0.0 & 3.9 & 0.0 & 8.7 & 0.0 & 7.6 & 7.6 & 0.0 & 0.0 & 0.0 \\
\hline Restructuring cost 8 & -5.5 & -7.5 & $-4,9$ & -10.1 & -6.0 & -13.4 & -7.6 & 5.8 & -25.0 & -79.7 & -33.1 \\
\hline Social costs & -5.5 & -7.5 & -4.9 & -10.1 & -6.0 & -13.4 & -7.6 & 5.8 & -25.0 & -22.4 & -22.0 \\
\hline Debt to CNSS & 0.0 & 0.0 & 0.0 & 0.0 & 0.0 & 0.0 & 0.0 & 0.0 & 0.0 & -57.4 & -11.1 \\
\hline Privatization proceeds & 4.0 & 8.8 & 3.4 & 13.1 & 3.4 & 17.5 & 3.4 & -14.1 & 10.0 & 8.5 & 8.5 \\
\hline Other & -11.8 & -6.3 & -7.8 & -0.2 & -71.2 & -1.8 & -70.8 & -69.0 & 0.0 & -18.0 & 0.0 \\
\hline Treasury correspondents, including pension & -4.7 & -5.0 & -13.1 & 0.0 & -19.7 & 0.0 & $-2 \mathrm{~L} .1$ & -21.1 & 0.0 & -10.0 & 0.0 \\
\hline Collectivités locales $9 /$ & -10.5 & -1.3 & -5.1 & 0.0 & -7.7 & -1.6 & -9.0 & -7.4 & 0.0 & -8.0 & 0.0 \\
\hline Cancellation of domestic debt & 22.7 & 0.0 & 0.0 & 0.0 & 0.0 & 0.0 & 0.0 & 0.0 & 0.0 & 0.0 & 0.0 \\
\hline Checks writen but not cashed at treasury & 1.8 & 0.0 & 1.1 & 0.0 & 6.6 & 0.0 & -1.8 & -1.8 & 0.0 & 0.0 & 0.0 \\
\hline Errors and omissions & $-2 \mathrm{~L} . \mathrm{I}$ & 0.0 & 9.3 & -0.2 & -50.4 & -0.2 & -38.9 & -38.7 & 0.0 & 0.0 & 0.0 \\
\hline Financing gap & 0.0 & 0.0 & 0.0 & 0.0 & 0.0 & 0.0 & 0.0 & 0.0 & 42.8 & 284.7 & 190.2 \\
\hline \multicolumn{12}{|l|}{ Metnorandum item: } \\
\hline Primaty fiscal balance (in percent of GDP) & 17.7 & 13.4 & 10.1 & 16.9 & 13.8 & 21.1 & 16.5 & -4.7 & 12.0 & 9.5 & 10.2 \\
\hline
\end{tabular}

Soures: Gabonese authorities; and staff estimates and projections.

1/ Staff projections include the proposed framework for the revised 2002 budget made in December 2001 and take into aweount most recent oil price projections, as well as the information on the availability of external financing and the budget execution at end-2001.

2/ The new debt service reflects bilateral negotiations with Paris Club creditors.

3/ Including equity participation in the manganese company COMILOG (CFAF 4.1 billion) and the payment of Air Gabon"s debt, as well as down payments for the purchase of airplanes for Air Gaben (CFAF 6.7 billion).

4/ End-June and end-September 200 larrears were cleared in July and October; new anrears were recorded during the last quarter of 2001.

End-200 Larears are to be cleared in 2002.

5/Other float at the treasury includes mainly variations in consignments and operations with autonomous borlies.

6/ The projections as well as the initial program for 2001 include CFAF 4.2 billion for the water and electricity company (SEEG) in 2001; the sevised program for 2001 also includes CFAF 0.7 billion to the National Social Security Fund (CNSS).

$7 /$ The inclusion of payments on "regularization of civil servants' salaries" under domestic financing rather than in the primary balance applies only to obligations incurred before 2001. Any such obligation incurred after 2000 will be considered as expenditure on wages.

8/Restructuring costs refer to social costs of privatization and vohuntary departures (ses the techical memorandum of understanding). The 2002 budget includes provisions for the repayment of the debt of public enteprises to social security (CNSS).

$9 /$ Collectivités locales includes variations in local entities' account balances and Fonds d'équipement. 


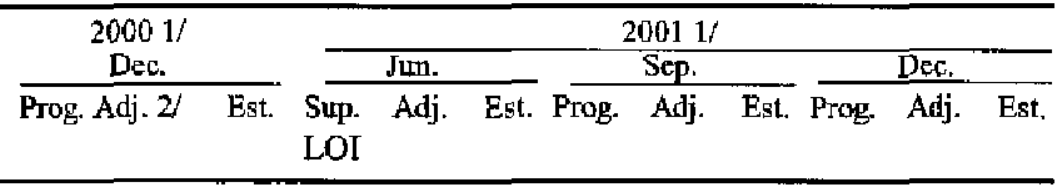

Performance criteria

Ceiling on the net claims of the banking system on the government (stock) $3 /$

Floor on cumulative deposits in the special azcount at the BEAC for any cash treasury surplus relted to higher oil

$\begin{array}{llllllllllll}212.9 & 6.0 & 128.9 & 105.7 & 140.8 & 187.8 & 140.1 & 90.5 & 250.6 & 129.1 & 42.6 & 273.6\end{array}$ revenues (stock) $4 /$

Ceiling on the contracting or guaranteeing of new nonconcessional extemal debt with original maturity of 1 to 12 years by the governunent 5 /

Ceiling on outstanding stock of new nonconcessional external debt with original maturity of less than one year owed or guaranteed by the government 6/
Limit on the net accumulation of external payments arrears $7 / \quad \mathbf{4 7 2 . 4}$

Floor on the net reduction of domestic payments arrears

Floor on the primary fiscal balance (on a payment order basis) $8 / 9 /$
0.0

..

0.0

.

20.0

$20.0 \quad 20.0$

$0.0 \quad 20.0$

$0.0 \quad 20.0$

Quantitative benchmarks
Floor on non-oil gowernment revenue

Ceiling on the government wage bill

Ceiling on total noninterest, nomwage expenditure (on a commitment basis) $9 / 10 /$

399.1

216.1

243.2

\author{
0.0
}

379.3

699.3

492.0

Rescheduling of external debt

Privatization proceeds

$\begin{array}{rrrr}0.0 & 0.0 & 0.0 & 0.0 \\ -482.2 & 0.0 & 27.0 & 0.0 \\ -74.9 & -12.9 & -76.1 & -17.1\end{array}$

$\begin{array}{rr}27.0 & 0.0 \\ -76.1 & -17.1\end{array}$

$0.0 \quad 0.0$

$95.6 \quad 0.0$

$-69.1-51.8$

0.0

59.9

$-70.9$

1/ Performance criteria for end-2000, end-June 2001, end-September 2001, and end-December 2001 , with the exception of the end-June 2001 targets for the primary fiscal balance and net bank credit to the government, which are indicative targets (see definitions and explanations in the technical memorandum of understanding (in EBS/01/56). The indicative targets for end-March 2002 were to be established at the time of the third quarterly review.

$2 /$ The criterion on the primary balanee for end-2000 is adjusted upward by CFAF 115.4 billion for higher-than-programmed oil revenues; the criterion on net bank credit to the government is adjusted downward by CFAF 115.4 billion for higher-than-programmed oil revenues; upward by CFAF 56.3 billion and CFAF 9.8 billion for larger-than-programmed reduction in domestic and external arrears, respectively; and downward by CFAF 157.5 billion for higher-thanprogrammed rescheduling of external debt. Similar adjustments wero made for end-March, end-June, end-September, and end-December 2001.

3/ The performance criterion will be adjusted downward for any higher oil revenues, larger nonproject extemal financing disbursements net of external debt service paid, and smaller net reduetions in domestic arrear's as defined in the TMU relative to program targets. It will be adjusted upward for any lower oil revenues or lower nonproject financing net of external debt service paid, and higher net rednetion in domestic arrears relative to the program targets, up to 50 percent of the total shortfall with a maximum of CFAF 30 billion (or 1 percent of GDP) in 2001 . If the oil revenue shortfall exceeds 2 percent of GDP in 2001, the quarterly fiscal targets will be reassessed in consultation with Fund staff. The criterion will also be adjusted downward/upward for any larger/smaller privatization proceeds, as defined in the TMU.

4/ If a tresury surpilus materializes in 2001, the corresponding amount will be deposited in a special accotunt at the Bank of Central African States (BEAC) and its eventual use will be discussed with the Fund staff in the context of the quarterly reviews. The floor on the cumulative amount deposited in the special account for the projected cash treasury surplus will be adjusted uptward for higher-than-projected oil revenue, and downward for lower-thanprojected oil revenue (down to lower than zero).

5/ This performance criterion applies not only to debt as defined in point No. 9 of the Guidelines on Perfarmance Criteria with Respect to Foreign Debt, adopted by the MFF Executive Board on August 24, 2000, but also to commitments contracted or guaranteed for which value has not been. received. Excluded from this performance criterion are rescheduling arrangements and purchases from the Fund. For purposes of this performance criterion, the term "nonconcessional" means that the debt has a grant element of less than 35 percent ealculated on the basis of currency-specific discount rates that are based on the OECD commercial interest reference rates (CIRRs).

6/ The term "debt" has the meaning set forth in point No. 9 of the Guidelines on Performance Criteria with Respect to Foreign Debt, adopted August 24, 2000. Excluded from this performance criterion are rescheduling arrangements, purcheses from the Fund, and normal import-related credits, For purposes of this performance criterion, the term "nonconcessional" means that the debt has a grant element of less than 35 percent calenlated on the basis of currency-specific discount rates that are based on the OECD commercial interest reference rates (CIRRs).

$7 /$ Continuous performance criterion.

8/ The performance criterion on the primary fiscal balance will be adjusted upward for any higher-than-programmed oil revernue, and adjusted downward for 50 percent of any lower-than-programmed oil revenue, with a maximum of CFAF 30 billion (or 1 percent of GDP) in 2001 for the downward adjustment. If the oil revenue shortfall exceeds 2 percent of GDP in 2001 , the quarterly fiscal targets will be reassessed in consultation with Fund staff.

$9 /$ Expenditure is measured an a commitment basis (engagements) up to and including 2000 , and on a payment order basis (ordonnancements) thereafter.

10/ Up to and inchuding 2000 (original program), only current noninterest, nomwage expenditure. As of 2001 (revised program), total noninterest, nonwage expenditure. 
Table 4. Gabon: Fiscal Operations of the Central Government, 1998-2007

\begin{tabular}{|c|c|c|c|c|c|c|c|c|c|c|c|}
\hline & 1998 & 1999 & 2000 & 200 & & $\underline{2002}$ & 2003 & 2004 & 2005 & 2006 & 2007 \\
\hline & & & & $\begin{array}{l}\text { Prog. } \\
\text { BS/01/56 }\end{array}$ & $\begin{array}{r}\text { Prel. } \\
\text { est. }\end{array}$ & & & Project & tions & & \\
\hline & & & & & billions & ofCFA & francs) & & & & \\
\hline Total revenue and grants & 912.1 & 813.6 & $1,207.6$ & $1,235.1$ & $1,190.1$ & 988.5 & 937.5 & 900.8 & 885.5 & 853.8 & 838.9 \\
\hline Revenue & 912.1 & 813.6 & $1,207.6$ & $1,235.1$ & $1,190.1$ & 986.6 & 937.5 & 900.8 & 885.5 & 853.8 & 838.9 \\
\hline Oil revenue & 498.3 & 368.6 & 814.7 & 760.1 & 781.4 & 478.1 & 413.8 & 347.9 & 304.3 & 239.6 & 200.4 \\
\hline Non-oil revenue $1 /$ & 413.8 & 445.0 & 392.9 & 475.0 & 408.8 & 508.5 & 523.7 & 552.9 & 581.1 & 614.2 & 638.6 \\
\hline Direct taxes & 107.6 & 91.6 & 81.9 & 89.3 & 99.0 & 120.0 & 121.5 & 128.7 & 136.8 & 145.5 & 154.3 \\
\hline Indirect taxes & 72.8 & 58.2 & 80.2 & 90.4 & 70.7 & 98.0 & 102.7 & 108.8 & 115.7 & 123.0 & 130.4 \\
\hline Taxes on international trade & 214.5 & 164,6 & 214.7 & 268.2 & 211.0 & 255.5 & 261.3 & 274.1 & 284.0 & 297.9 & 300.8 \\
\hline Import taxes & 200.8 & 146.7 & 186.1 & 230.3 & 184.1 & 220.0 & 219.7 & 226.1 & 234.2 & 241.2 & 241.8 \\
\hline Of which: VAT & 95.4 & 71.9 & 83.6 & $\ldots$ & 90.2 & 107.8 & 107.7 & 110.8 & 114.8 & 118.2 & 118.5 \\
\hline Export taxes & 13.7 & 17.9 & 28.6 & 37.9 & 26.9 & 35.5 & 41.5 & 48.0 & 49.8 & 56.8 & 59.0 \\
\hline Other revenue & 18.8 & 130.6 & 16.1 & 27.1 & 28.2 & 35.0 & 38.2 & 41.3 & 44.6 & 47.8 & 53.1 \\
\hline Foreign grants & 0.0 & 0.0 & 0.0 & 0.0 & 0.0 & 1.9 & 0.0 & 0.0 & 0.0 & 0.0 & 0.0 \\
\hline $\begin{array}{l}\text { Total expenciture (including } \\
\text { net lending) }\end{array}$ & $1,281.6$ & 779.5 & 7861 & 9071 & 9342 & 8318 & 7501 & 7196 & 7015 & 6874 & 6250 \\
\hline Total expenditure (excluding & & & & & & & & & & & \\
\hline interest payments) & $1,080.0$ & 583.6 & 574.1 & 580.1 & 631.5 & 666.1 & 604.7 & 582.3 & 574.0 & 572.9 & $\$ 76.7$ \\
\hline Current expenditure & 918.8 & 660.6 & 674.8 & 782.0 & 790.9 & 611.8 & 574.1 & 542.6 & 514.5 & 492.7 & 488.3 \\
\hline Wages and salaries & 204.9 & 214.0 & 216.6 & 217.9 & 213.4 & 196.0 & 188.0 & 177.0 & 166.0 & 159.4 & 157.5 \\
\hline Purchases of goods and & & & & & & & & & & & \\
\hline services & 204.2 & 124.2 & 128.3 & 133.6 & 135.5 & 130.0 & 132.6 & 135.3 & 138.0 & 140.8 & 143.6 \\
\hline Transfers and subsidies & 308.1 & 126.5 & 117.8 & 103.5 & 139.2 & 120.0 & 108.0 & 93.0 & 83.0 & 78.0 & 78.0 \\
\hline Interest payments & 201.6 & 195.9 & 212.0 & 327.0 & 302.8 & 165.8 & 145.4 & 137.2 & 127.4 & 114.6 & 109.2 \\
\hline Domestic & 24.2 & 25.6 & 27.8 & 33.1 & 34.6 & 23.3 & 20.5 & 18.9 & 17.4 & 12.8 & 12.8 \\
\hline External (excluding IMF) & 177.3 & 170.3 & 184.2 & 293.9 & 268.2 & 142.4 & 124.9 & 118.3 & 110.0 & 101.8 & 96.4 \\
\hline Capital expenditure & 362.8 & 118.9 & 105.1 & 125.1 & 118.3 & 200.0 & 176.0 & 177.0 & 187.0 & 194.7 & 197.5 \\
\hline Domestically financed & & & & & & & & & & & \\
\hline investment & 333.9 & 89.7 & 82.4 & 105.1 & 113.2 & 135.0 & 131.0 & 132.0 & 137.0 & 139.7 & 142.5 \\
\hline Foreign-financed investment & 28.9 & 29.2 & 22.7 & 20.0 & 5.1 & 65.0 & 45.0 & 45.0 & 50.0 & 55.0 & 55.0 \\
\hline Net lending (including equity & & & & & & & & & & & \\
\hline participation) & 0.0 & 0.0 & 6.2 & 0.0 & 25.1 & 20.0 & 0.0 & 0.0 & 0.0 & 0.0 & 0.0 \\
\hline Overall balance (on a & & & & & & & & & & & \\
\hline commitment basis) & -369.4 & 34.1 & 421.5 & 328.0 & 255.9 & 156.7 & 187.4 & 181.2 & 184.0 & 166.4 & 153.1 \\
\hline Primary balance (on a & & & & & & & & & & & \\
\hline commitment basis) & -167.9 & 230.0 & 633.5 & 655.0 & 558.7 & 322.5 & 332.8 & 318.4 & 311.4 & 281.0 & 262.3 \\
\hline Change in arrears & 80.9 & 3.3 & -276.2 & -51.8 & -42.0 & -28.9 & -30.0 & 0.0 & 0.0 & 0.0 & 0.0 \\
\hline External & 97.8 & 103.5 & -201.3 & 0.0 & 28.9 & -28.9 & 0.0 & 0.0 & 0.0 & 0.0 & 0.0 \\
\hline Domestic & -16.8 & -100.2 & -74.9 & -51.8 & -70.9 & 0.0 & -30.0 & 0.0 & 0.0 & 0.0 & 0.0 \\
\hline Overall balance (on a cash basis) & -288.5 & 37.4 & 145.4 & 276.2 & 214.0 & 127.8 & 157.3 & 181.2 & 184.0 & 166.4 & 153.1 \\
\hline Financing & 288.5 & -37.4 & -145.4 & -276.2 & -214.0 & -318.0 & -254.7 & -261.6 & -249.1 & -229.6 & -220.6 \\
\hline
\end{tabular}


Table 4. Gabon: Fiscal Operations of the Central Government, 1998-2007

\begin{tabular}{|c|c|c|c|c|c|c|c|c|c|c|c|}
\hline & \multirow[t]{2}{*}{1998} & \multirow[t]{2}{*}{1999} & \multirow[t]{2}{*}{2000} & \multicolumn{2}{|c|}{2001} & \multirow[t]{2}{*}{2002} & \multirow[t]{2}{*}{2003} & \multirow{2}{*}{\multicolumn{2}{|c|}{$\begin{array}{l}2004 \quad 2005 \\
\text { Projections }\end{array}$}} & \multirow[t]{2}{*}{2006} & \multirow[t]{2}{*}{2007} \\
\hline & & & & $\begin{array}{l}\text { Prog. } \\
\text { S/01/56 }\end{array}$ & $\begin{aligned} \text { Prel. } \\
\text { est. }\end{aligned}$ & & & & & & \\
\hline & \multicolumn{11}{|c|}{ (In billions of CFA francs) } \\
\hline External (net) & -14.2 & -5.1 & 160.2 & -238.1 & -209.2 & -199.0 & -159.4 & -173.0 & -165.7 & -162.5 & -162.8 \\
\hline Drawings & 28.9 & 29.2 & 22.7 & 20.0 & 5.1 & 65.0 & 45.0 & 45.0 & 50.0 & 55.0 & 55.0 \\
\hline Amortization & -191.6 & -194.5 & -242.1 & -281.0 & -297.7 & -233.0 & -204.4 & -218.0 & -215.7 & -217.5 & -217.8 \\
\hline Arrears & 129.5 & 142.1 & -271.6 & 0.0 & 31.0 & -31.0 & 0.0 & 0.0 & 0.0 & 0.0 & 0.0 \\
\hline Foreign exchange effect on arrears & $\ldots$ & $\ldots$ & -9.3 & 0.0 & 0.0 & 0.0 & 0.0 & 0.0 & 0.0 & 0.0 & 0.0 \\
\hline Debt rescheduling and deferral $2 /$ & 0.0 & 0.0 & 649.5 & 0.0 & 29.4 & 0.0 & 0.0 & 0.0 & 0.0 & 0.0 & 0.0 \\
\hline Debt cancellation & 19.0 & 18.0 & 17.0 & 17.0 & 17.0 & 0.0 & 0.0 & 0.0 & 0.0 & 0.0 & 0.0 \\
\hline Advance external debt payment & 0.0 & 0.0 & -5.9 & 5.9 & 5.9 & 0.0 & 0.0 & 0.0 & 0.0 & 0.0 & 0.0 \\
\hline Domestic (net) & 302.7 & -32.3 & -305.7 & -38.2 & -4.7 & -119.0 & -95.3 & -88.6 & -83.4 & -67.2 & -57.8 \\
\hline Banking system & 122.0 & -24.6 & -175.6 & 0.2 & 144.7 & -57.1 & -70.6 & -70.0 & -65.7 & -49.4 & -40.0 \\
\hline BEAC & 127.2 & -24.3 & -59.1 & 15.3 & 109.5 & -57.1 & -70.6 & -70.0 & -65.7 & -49.4 & -40.0 \\
\hline Of which: IMF & -13.4 & -15.1 & 5.4 & -7.9 & -3.7 & -9.3 & -9.3 & -15.3 & -15.2 & -5.5 & 0.0 \\
\hline Statutory advances & 0.0 & 0.0 & 0.0 & 0.0 & 0.0 & 0.0 & -20.0 & -20.0 & -20.0 & -20.0 & -20.0 \\
\hline Fund for Future Generations & 0.0 & 0.0 & 0.0 & 0.0 & 0.0 & -47.8 & -41.4 & -34.8 & -30.4 & -24.0 & -20.0 \\
\hline Commercial banks & -5.2 & -0.2 & -116.5 & -1.5 .1 & 35.2 & 0.0 & 0.0 & 0.0 & 0.0 & 0.0 & 0.0 \\
\hline Nonbank sources & 180.8 & $-7,8$ & -130.1 & -38.4 & -149.4 & -61.9 & -24.6 & -18.6 & -17.7 & -17.7 & -17.7 \\
\hline Domestic debt & 7.3 & -26.9 & -115.0 & -40.7 & -82.1 & -37.2 & -24.6 & -18.6 & -17.7 & -17.7 & -17.7 \\
\hline Oil company advances (net) & 29.4 & -19.9 & -36.4 & 0.0 & 0.0 & 0.0 & 0.0 & 0.0 & 0.0 & 0.0 & 0.0 \\
\hline Debt DGCP & -22.1 & -7.0 & -72.1 & -35.7 & -74.2 & -32.2 & -24.6 & -18.6 & -17.7 & -17.7 & -17.7 \\
\hline $\begin{array}{l}\text { Regularization of civil servants' } \\
\text { salaries (rappels) }\end{array}$ & 0.0 & 0.0 & -6.5 & -5.0 & -7.9 & -5.0 & 0.0 & 0.0 & 0.0 & 0.0 & 0.0 \\
\hline $\begin{array}{l}\text { Change in domestic arrears (on } \\
\text { principal - reduction) }\end{array}$ & 0.0 & 0.0 & -2.0 & 0.0 & 7.6 & 0.0 & 0.0 & 0.0 & 0.0 & 0.0 & 0.0 \\
\hline Restructuring cost & 0.0 & 0.0 & -5.5 & -13.4 & -7.6 & -33.1 & 0.0 & 0.0 & 0.0 & 0.0 & 0.0 \\
\hline Privatization proceeds & 0.4 & 2.0 & 4.0 & 17.5 & 3.4 & 8.5 & 0.0 & 0.0 & 0.0 & 0.0 & 0.0 \\
\hline Other $3 /$ & 173.1 & 17.1 & -11.6 & -1.8 & -70.8 & 0.0 & 0.0 & 0.0 & 0.0 & 0.0 & 0.0 \\
\hline Financing gap & 0.0 & 0.0 & 0.0 & 0.0 & 0.0 & 190.2 & 97.3 & 80.4 & 65.1 & 63.2 & 67.5 \\
\hline
\end{tabular}

Memorandum items:

Cumulative variation in net bank credit

to the govemment from January 1,2000

(in billions of CFA francs)

Total revenue (excluding grants)

Oil revenue

Non-oil revenue

Total expenditure

Total expenditure, excluding interest

Current expenditure

Wage bill

Other current spending

Interest
(In percent of GDP, unless otherwise specified)

$\begin{array}{rrrrrrrrrrr} & & -175.6 & -175.4 & -30.9 & & & & & & \\ 34.5 & 28.7 & 33.8 & 39.9 & 35.1 & 31.3 & 30.3 & 29.1 & 28.2 & 26.8 & 25.6 \\ 18.8 & 13.0 & 22.8 & 24.5 & 23.1 & 15.1 & 13.4 & 11.2 & 9.7 & 7.5 & 6.1 \\ 15.6 & 15.7 & 11.0 & 15.3 & 12.1 & 16.1 & 16.9 & 17.8 & 18.5 & 19.3 & 19.5 \\ 48.5 & 27.5 & 22.0 & 29.3 & 27.6 & 26.4 & 24.2 & 23.2 & 22.3 & 21.6 & 21.0 \\ 40.8 & 20.6 & 16.0 & 18.7 & 18.6 & 21.1 & 19.5 & 18.8 & 18.3 & 18.0 & 17.6 \\ 34.7 & 23.3 & 18.9 & 25.2 & 23.3 & 19.4 & 18.5 & 17.5 & 16.4 & 15.4 & 14.9 \\ 7.7 & 7.5 & 6.1 & 7.0 & 6.3 & 6.2 & 6.1 & 5.7 & 5.3 & 5.0 & 4.8 \\ 19.4 & 8.8 & 6.9 & 7.7 & 8.1 & 7.9 & 7.8 & 7.4 & 7.0 & 6.9 & 6.8 \\ 7.6 & 6.9 & 5.9 & 10.6 & 8.9 & 5.3 & 4.7 & 4.4 & 4.1 & 3.6 & 3.3\end{array}$


Table 4. Gabon: Fiscal Operations of the Central Government, 1998-2007

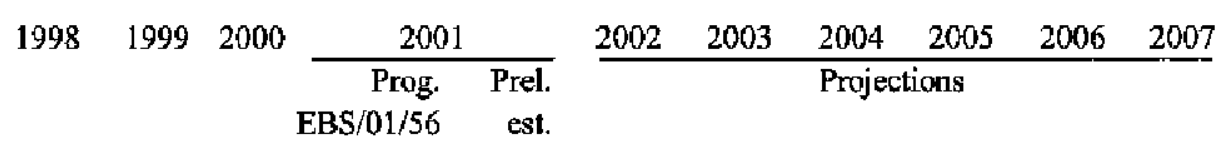

(In percent of GDP, unless otherwise specified)

\begin{tabular}{|c|c|c|c|c|c|c|c|c|c|c|c|}
\hline Capital expenditure & 13.7 & 4.2 & 2.9 & 4.0 & 3.5 & 6.3 & 5.7 & 5.7 & 5.9 & 6.1 & 6.0 \\
\hline Defense expenditure 4/ & 2.3 & 1.9 & 1.8 & $\ldots$ & 1.9 & $\ldots$ & $\ldots$ & $\ldots$ & $\ldots$ & $\ldots$ & $\ldots$ \\
\hline $\begin{array}{l}\text { Primary balance (on a } \\
\text { commitment basis) }\end{array}$ & -6.3 & 8.1 & 17.7 & 21.1 & 16.5 & 10.2 & 10.8 & 10.3 & 9.9 & 8.8 & 8.0 \\
\hline $\begin{array}{l}\text { Overall balance (on a } \\
\text { commitment basis) }\end{array}$ & -14.0 & 1.2 & 11.8 & 10.6 & 7.6 & 5.0 & 6.1 & 5.8 & 5.9 & 5.2 & 4.7 \\
\hline Overall balance (on a cash basis) & -10.9 & 1.3 & 4.1 & 8.9 & 6.3 & 4.0 & 5.1 & 5.8 & 5.9 & 5.2 & 4.7 \\
\hline & \multicolumn{11}{|c|}{ (In percent of non-oil GDP) } \\
\hline Non-oil revenue & 21.7 & 25.1 & 21.3 & 23.8 & 21.1 & 24.5 & 24.1 & 24.0 & 23.7 & 23.6 & 23.1 \\
\hline & \multicolumn{11}{|c|}{ (In billions of CFA francs, unless otherwise specified) } \\
\hline $\begin{array}{l}\text { Program oil prices in EBS } / 01 / 56 \\
\text { (in U.S. dollars per barrel) } 5 /\end{array}$ & 13.1 & 18.1 & 28.2 & 23.0 & 24.3 & 21.5 & 20.0 & 19.8 & 19.5 & 19.5 & $\ldots$ \\
\hline GDP at market prices & 2,645 & 2,840 & 3,577 & 3,098 & $3,3.87$ & 3,157 & 3,096 & 3,099 & 3,143 & 3,189 & 3,272 \\
\hline
\end{tabular}

Sources: Gabonese authorities; and staff estimates and projections.

1/ For 1999, includes CFAF 94.9 billion (3.4 percent of GDP) in tax arrears recovered as a result of the andit of the domestic public debt.

2/ See Box 1 of EBS/01/56 (4/12/2001).

3/ Includes treasury correspondents, local governments, checks written but not yet cashed, and errors and omissions.

4/ Defense spending is partly included under current expenditure and partly under capital spending, in line with Gabon's existing budget classification. The budget classification is being revised, so as to include all defense spending under current expenditure.

5/ The corresponding national oil prices are about US\$1 lower. 
Table 5, Gabon: Monetary Survey, 1998-2002

\begin{tabular}{|c|c|c|c|c|c|c|}
\hline & \multirow{3}{*}{$\begin{array}{l}1998 \\
\text { Dec. }\end{array}$} & \multirow{3}{*}{$\begin{array}{c}1999 \\
\text { Dec. }\end{array}$} & \multirow{3}{*}{$\begin{array}{l}2000 \\
\text { Dec. }\end{array}$} & \multicolumn{2}{|c|}{2001} & \multirow{3}{*}{$\begin{array}{l}2002 \\
\text { Dec } \\
\text { Proj }\end{array}$} \\
\hline & & & & \multicolumn{2}{|c|}{ Dec. } & \\
\hline & & & & $\begin{array}{l}\text { Prog. } \\
5 / 01 / 56\end{array}$ & $\begin{array}{r}\text { Prel. } \\
\text { est. }\end{array}$ & \\
\hline Monetary survey & \multicolumn{6}{|c|}{ (In billions of CFA francs; end of period) } \\
\hline Net foreign assets & -46.0 & -44.0 & 177.2 & 150.6 & -8.1 & 20.4 \\
\hline Central bank & $-54,4$ & -42.1 & 72.8 & 61.7 & -46.0 & 12.5 \\
\hline Deposit money banks & 8.3 & -1.9 & 104,4 & 89.0 & 37.9 & 7.9 \\
\hline Net domestic assets & 505.6 & 491.0 & 350.1 & 386.9 & 574.8 & 574,3 \\
\hline Net domestic credit & 631.8 & 606.3 & 455.6 & 489.3 & 660.2 & 659.7 \\
\hline Net credit to the public sector & 315.4 & 286.6 & 98.6 & 94.9 & 241.0 & 183.9 \\
\hline Net credit to the government & 329.1 & 304.5 & 128.9 & 129.1 & 273.6 & 216.5 \\
\hline Central bank & 199.0 & 174.7 & 114.2 & 129.0 & 223.6 & 166.5 \\
\hline Deposit money banks & 127.6 & 127.4 & 10.9 & -3.2 & 47.7 & 47.7 \\
\hline Post office savings & 2.5 & 2.4 & 3.9 & 3.3 & 2.3 & 2.3 \\
\hline Claims on public agencies, net & -13.7 & -17.9 & -30.3 & -34.2 & -32.6 & -32.6 \\
\hline Credit to the economy & 316.5 & 319.6 & 356.9 & 394.4 & 419.2 & 475.8 \\
\hline Other items, net & -126.2 & -115.3 & -105.4 & -102.4 & -85.4 & -85.4 \\
\hline Broad money & 459.6 & 447.0 & 527.3 & 537.5 & 566.7 & 594.7 \\
\hline Currency outside banks & 124.7 & 105.3 & 116.2 & 118.5 & 128.2 & 134.5 \\
\hline Demand deposits & 158.4 & 163.6 & 204.3 & 208.0 & 204.0 & 214.1 \\
\hline Time deposits & 176.5 & 178.2 & 206.9 & 211.0 & 234.5 & 246.1 \\
\hline \multicolumn{7}{|l|}{ Central bank } \\
\hline Net foreign assets & -54.4 & -42.1 & 72.8 & 61.7 & -46.0 & 12.5 \\
\hline Assets & 10.7 & 14.1 & 136.5 & 119.8 & 9.9 & 58.4 \\
\hline Liabilities & -65.1 & -56.2 & -63.7 & -58.1 & -56.0 & -45.9 \\
\hline Net domestic assets & 206.5 & 182.1 & 119.1 & 134.7 & 230.5 & 170.0 \\
\hline Net credit to the government & 199.0 & 174.7 & 114.2 & 129,0 & 223.6 & 166.5 \\
\hline Claims & 211.1 & 200.8 & 157.3 & 147.6 & 248.2 & 238.9 \\
\hline Statutory advances & 146.1 & 143.1 & 94.5 & 93.5 & 192.6 & 193.3 \\
\hline Use of IMF credit & 63.4 & 56.0 & 62.8 & 54.1 & 55.6 & 45.6 \\
\hline Deposits & 12.1 & 26.1 & 43.2 & 18.6 & 24.6 & 72.4 \\
\hline Of which: Fund for Future Generations & 0.0 & 0.0 & 0.0 & 0.0 & 0.0 & 47.8 \\
\hline Claims on deposit money banks & 8.1 & 12.5 & 0.3 & 0.2 & 3.1 & -0.3 \\
\hline Claims on nonbank institutions & 0.0 & 0.0 & 0.0 & 0.0 & 0.0 & 0.0 \\
\hline Other items, net & -0.5 & -4.2 & 4.7 & 5.5 & 3.9 & 3.9 \\
\hline Reserve money & 152.2 & 140.0 & 191.9 & 196.4 & 184.5 & 182.6 \\
\hline Currency outside banks & 124.7 & 105.3 & 116.2 & 118.5 & 128.2 & 134.5 \\
\hline Banks' reserves & 27.5 & 34.8 & 75.7 & 77.9 & 56.3 & 48.0 \\
\hline Deposits at BEAC & 18.2 & 18.3 & 53.6 & 54.9 & 36.2 & 28,0 \\
\hline Currency in vault & 9.2 & 16.4 & 22.2 & 23.1 & 20.1 & 20.0 \\
\hline
\end{tabular}


Table 5. Gabon: Monetary Survey, 1998-2002

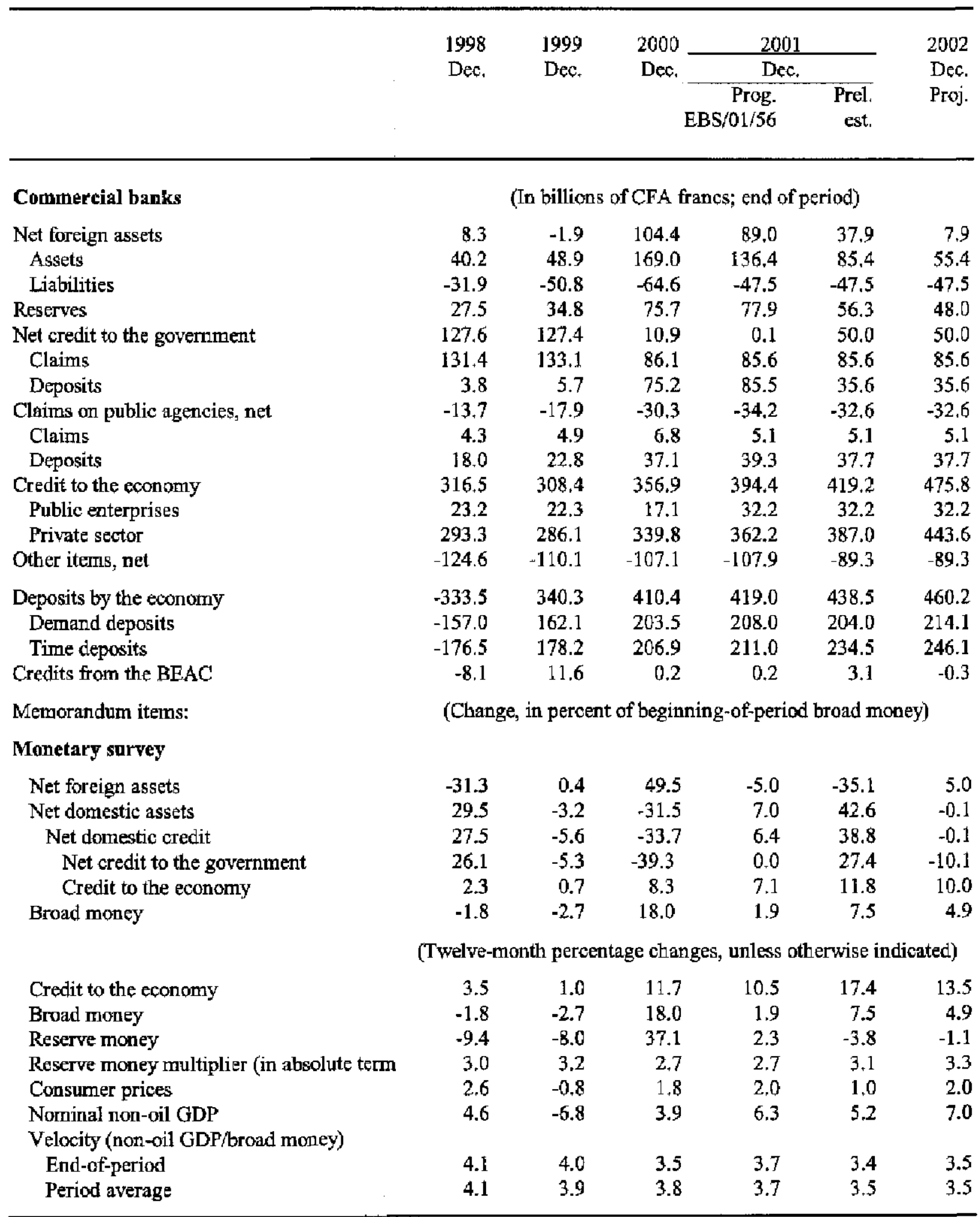

Sources: Bank of Central African States (BEAC); and staff estimates and projections. 
Table 6. Gabon: Balance of Payments, 1997-2007

\begin{tabular}{|c|c|c|c|c|c|c|c|c|c|c|}
\hline 1997 & 199 & 1999 & 2000 & 2001 & 2002 & 2003 & 2004 & 2005 & 2006 & 2007 \\
\hline
\end{tabular}

(In billions of CFA francs)

\begin{tabular}{|c|c|c|c|c|c|c|c|c|c|c|c|c|}
\hline $\begin{array}{l}\text { Current account (including } \\
\text { ofticial transfers) }\end{array}$ & 86.6 & -495.0 & -251.1 & 115.9 & 17.0 & -35.7 & -152.9 & -159.1 & -186.8 & -175.5 & -194.0 & -166.1 \\
\hline Expotts, f.o.b. & $1,790.5$ & $1,124.8$ & $1,540.0$ & $2,285.3$ & $1,665.3$ & $1,929.2$ & $1,568.2$ & $1,412.4$ & $1,296.3$ & $1,208.9$ & $1,119.3$ & $1,067.3$ \\
\hline Oil sector & $1,401.9$ & 833.4 & $1,143.2$ & $1,827.8$ & $1,214,9$ & $1,509.1$ & $1,128.8$ & 955.9 & 821.0 & 711.7 & 597.3 & 517.4 \\
\hline Other sectors & 388.5 & 291.4 & 396.8 & 457.4 & 450.9 & 420.1 & 439.4 & 456.5 & 475.3 & 497.2 & 522.0 & 549.9 \\
\hline Imports, f.o.b. & -566.3 & -650.7 & -521.3 & -658.0 & -625.0 & -731.4 & -756.4 & -737.8 & -730.5 & -718.7 & -713.4 & -688.9 \\
\hline Oil sector & -244.4 & -178.4 & -179.2 & -285.4 & -143.0 & -300.2 & -278.0 & -264.7 & -252.2 & -231.4 & -217.3 & -191.6 \\
\hline Govemment & -121.6 & -200.7 & -49.6 & -37.5 & -59.6 & -56.3 & -86.0 & -77.2 & .77 .9 & -81.8 & -85.0 & -86.3 \\
\hline Non-oil private sector & -200.3 & -271.5 & -292.6 & -335.2 & -422.5 & -374.9 & -392.3 & -395.9 & -400.4 & -405.5 & -411.0 & -411.0 \\
\hline Trade balance & $1,224.1$ & 474.2 & $1,018.7$ & $1,627.2$ & $1,040.3$ & $1,197.7$ & 811.9 & 674.6 & 565.9 & 490.1 & 405.9 & 378.4 \\
\hline $\begin{array}{l}\text { Services (net) } \\
\text { Of which: interest on public }\end{array}$ & $-1,002.2$ & -853.1 & $-1,157.9$ & $-1,476.1$ & -918.5 & $-1,200.0$ & -935.5 & -803.2 & -722.2 & -635.0 & -568.9 & -512.9 \\
\hline debt (including IMF) & -166.2 & -180.8 & -172.8 & -187.0 & -296.7 & -271.0 & -145.7 & -127.7 & -120.5 & -111.5 & -102.4 & -96.4 \\
\hline Profits & -353.0 & -160.8 & -539.2 & -779.1 & -261.6 & -442.1 & -359.3 & -294.9 & -262.1 & -226.6 & -202.7 & -186.0 \\
\hline Transfers (net) & -135.3 & -116.1 & -111.8 & -35.3 & -104.8 & -33.4 & -29.3 & -30.5 & -30.4 & -30.7 & -31.0 & -31.6 \\
\hline Public & 0.0 & 0.0 & 0.0 & 0.0 & 0.0 & 0.0 & 1.9 & 0.0 & 0.0 & 0.0 & 0.0 & 0.0 \\
\hline Private & -135.3 & -116.1 & -111.8 & -35.3 & -104.8 & -33.4 & -31.2 & -30.5 & -30.4 & -30.7 & -31.0 & -31.6 \\
\hline Capital account & -206.7 & 102.1 & -0.3 & -179.3 & -51.6 & -195.4 & 81.2 & 92.0 & 156.6 & 155.8 & 160.9 & 120.1 \\
\hline Medium- and long-term capital & -82.6 & -41.1 & -60.6 & -26.4 & -113.9 & -307.0 & 30.1 & 99.8 & 169.8 & 172.6 & 175.3 & 140.9 \\
\hline Government & -146.9 & -162.7 & -165.3 & -219.4 & -261.0 & -292.6 & -168.0 & -159.4 & -173.0 & -165.7 & -162.5 & -162.8 \\
\hline Drawings (projects) & 53.8 & 28.9 & 29.2 & 22.7 & 20.0 & 5]$. & 65.0 & 45.0 & 45.0 & 50.0 & 55.0 & 55.0 \\
\hline Amortization & -200.7 & -191.6 & -194.5 & -242.1 & -281.0 & -297.7 & -233.0 & -204.4 & -218.0 & -215.7 & -217.5 & -217.8 \\
\hline Direct and portfolio investment & 2.5 & 93.8 & 100.1 & 137.5 & 71.6 & -82.7 & 136.2 & 186.9 & 267.0 & 257.8 & 255.2 & 217.8 \\
\hline Private debt & 61.8 & 27.8 & 4.6 & 55.5 & 75.6 & 68.3 & 62.0 & 72.4 & 75.8 & 80.5 & 82.5 & 85.9 \\
\hline Oil sector & 51.7 & 6.2 & -13.7 & 19.9 & 43.3 & 19.9 & 21.3 & 22.6 & 23.7 & 24.6 & 25.4 & 26.1 \\
\hline Drawings & 130.3 & 86.5 & 72.8 & 39.9 & 112.3 & 37.9 & 37.5 & 37.2 & 36.8 & 36.4 & 36.0 & 35.7 \\
\hline Amortization & -78.6 & -80.3 & -86.5 & -20.0 & -69.0 & -18.0 & -16.2 & -14.6 & -13.1 & -11.8 & -10.6 & -9.6 \\
\hline Non-oil sector & 10.1 & 21.6 & 18.3 & 35.6 & 32.3 & 48.4 & 40.6 & 49.8 & 52.1 & 55.9 & 57.1 & 59.8 \\
\hline Drawings & 48.7 & 31.9 & 29.0 & 41.4 & 44.4 & 53.7 & 46.3 & 55.6 & 58.2 & 62.2 & 63.8 & 66.8 \\
\hline Amortization & -38.6 & -10.3 & -10.7 & -5.8 & -12.2 & -5.4 & -5.6 & -5.8 & -6.1 & -6.3 & -6.7 & -7.0 \\
\hline
\end{tabular}


Table 6. Gabon: Balance of Payments, 1997-2007

$1997 \quad 1998 \quad 1999 \quad 2000$

Prog. Prel.

EBS/01/56 est.

\begin{tabular}{llllll}
2002 & 2003 & 2004 & 2005 & 2006 & 2007 \\
\hline & Projections
\end{tabular}

(n)

\begin{tabular}{|c|c|c|c|c|c|c|c|c|c|c|c|c|}
\hline \multirow[b]{2}{*}{ Short-term capital } & \multicolumn{12}{|c|}{ (In billions of CFA franes) } \\
\hline & -124.1 & 143.1 & 60.3 & -152.9 & 62.4 & 111.6 & 51.1 & -7.8 & -13.2 & -16.8 & -14.3 & -20.8 \\
\hline Oil sector & -76.1 & 124.9 & -86.5 & -57.4 & 13.1 & 28.1 & $2 B .2$ & 9.9 & 7.3 & 4.5 & 6.2 & 2.3 \\
\hline Non-oil sector & -28.8 & 49.7 & -25.3 & -111.2 & 49.3 & 83.4 & 22.9 & -17.6 & -20.5 & -21.3 & -20.6 & -23.0 \\
\hline Of which : commercial banks & 25.6 & 0.0 & 10.2 & -106.3 & 15.7 & 66.5 & 30.0 & 5.0 & 0.0 & 0.0 & 0.0 & 0.0 \\
\hline Errors and omissions & -19.2 & -31.5 & 172.1 & 15.6 & 0.0 & 0.0 & 0.0 & 0.0 & 0.0 & 0.0 & 0.0 & 0.0 \\
\hline Overall balance & -120.0 & -393.0 & -251.4 & -63.5 & -34.5 & -231.0 & -71.8 & -67.0 & -30.2 & -19.8 & -33.1 & -46.0 \\
\hline \multicolumn{12}{|l|}{ Central bank net foreign } & -21.5 \\
\hline assets (- $=$ increase) & -22.9 & 146.7 & -12.2 & -114.9 & 11.5 & 118.8 & -58.6 & -30.3 & -50.2 & -45.3 & -30.1 & -21.5 \\
\hline IMF & 11.2 & -13.4 & -15.1 & 5.4 & -7.9 & -8.1 & -9.3 & -9.3 & -15.3 & -15.2 & -5.5 & 0.0 \\
\hline Purchases & 13.3 & 0.0 & 0.0 & 12.4 & 0.0 & 0.0 & 0.0 & 0.0 & 0.0 & 0.0 & 0.0 & 0.0 \\
\hline Repurchases & -2.1 & -13.4 & -15.1 & -7.0 & -7.9 & -8.1 & -9.3 & -9.3 & -15.3 & -15.2 & -5.5 & 0.0 \\
\hline Other net assets ( $=$ increase) & -34.1 & 160.1 & 2.8 & -120.3 & 19.4 & 127.0 & -49.3 & -21.0 & -34.9 & -30.1 & -24.7 & -21.5 \\
\hline Debt rescheduling/deferral & 122.9 & 0.0 & 0.0 & 649.5 & 0.0 & 29.4 & 0.0 & 0.0 & 0.0 & 0.0 & 0.0 & 0.0 \\
\hline Debt cancellation & 20.0 & 19.0 & 18.0 & 17.0 & 17.0 & 17.0 & 0.0 & 0.0 & 0.0 & 0.0 & 0.0 & 0.0 \\
\hline Arrears (- = reduction) & 0.0 & 227.2 & 245.6 & -482.2 & 0.0 & 59.9 & -59.9 & 0.0 & 0.0 & 0.0 & 0.0 & 0.0 \\
\hline Other exceptional financing & 0.0 & 0.0 & 0.0 & -5.9 & 5.9 & 5.9 & 0.0 & 0.0 & 0.0 & 0.0 & 0.0 & 0.0 \\
\hline Financing gap (-) & 0.0 & 0.0 & 0.0 & 0.0 & 0.0 & 0.0 & 190.2 & 97.3 & 80.4 & 65.1 & 63.2 & 67.5 \\
\hline Memorandum ilerns: & \multicolumn{12}{|c|}{ (In percent of GDP, unless indicated otherwise) } \\
\hline \multicolumn{13}{|l|}{ Current account (including } \\
\hline official transfers) & 2.8 & -18.7 & -8.8 & 3.2 & 0.5 & -1.1 & -4.8 & -5.1 & -6.0 & -5.6 & -6.1 & -5.1 \\
\hline Oil sector & 12.4 & 7.3 & 4.0 & 14.3 & 16.5 & 15.2 & 8.2 & 6.7 & 5.0 & 4.5 & 2.9 & 2.5 \\
\hline Non-oil sector & -9.7 & -26.0 & -12.9 & -11.1 & -16.0 & -16.2 & -13.1 & -11.9 & -11.1 & -10.0 & -9.0 & -7.6 \\
\hline Capital account & -6.6 & 3.9 & 0.0 & -5.0 & -1.7 & -5.8 & 2.6 & 3.0 & 5.1 & 5.0 & 5.0 & 3.7 \\
\hline Overall balance & -3.9 & -14.9 & -8.9 & -1.8 & -1.1 & -6.8 & -2.3 & -2.2 & -1.0 & -0.6 & -1.0 & -1.4 \\
\hline $\begin{array}{l}\text { Gross official teserves (in } \\
\text { billions of CFA francs) }\end{array}$ & 171.4 & 10.7 & 14.1 & 136.5 & 124.9 & 9.9 & 58.4 & 79.2 & 114.1 & 144.1 & 168.8 & 190.3 \\
\hline $\begin{array}{l}\text { In months of imports } \\
\text { Word oil price (U.S. dollars }\end{array}$ & 3.6 & 0.2 & 0.3 & 2.5 & 2.4 & 0.2 & 0.9 & 1.3 & 1.9 & 2.4 & 2.8 & 3.3 \\
\hline per barrel) & 19.3 & 13.1 & 18.0 & 28.2 & 23.0 & 24.3 & 20.0 & 20.0 & 20.0 & 20.0 & 19.5 & 19.5 \\
\hline \multicolumn{13}{|l|}{ National oil price (U.S. dollars } \\
\hline per barrel) & 18.1 & 11.6 & 16.9 & 27.2 & 22.0 & 22.6 & 18.2 & 18.1 & 18.2 & 18.2 & 17.6 & 17.6 \\
\hline Oil production (million tons) & 18.5 & 17.6 & 15.6 & 13.6 & 11.3 & 13.0 & 12.1 & 10.4 & 9.0 & 7.9 & 6.9 & 6.0 \\
\hline GDP (billions of CFA francs) & $3,109.1$ & $2,645.0$ & $2,839.6$ & $3,576.9$ & $3,098.0$ & $3,387.4$ & $3,156.9$ & $3,095.5$ & $3,098.7$ & $3,143.1$ & $3,189.3$ & $3,272.1$ \\
\hline \multicolumn{13}{|l|}{ Exchange rate (CFA francs per } \\
\hline U.S. dollar; average) & 583.7 & 590.0 & 614.9 & 710.0 & 694.6 & 732.5 & 728.9 & 724.6 & 721.2 & 718.4 & 715.9 & 713.4 \\
\hline
\end{tabular}

Sources: Gabonese authorities; and Fund staff estimates and projections. 
Table 7. Gabon : External Public Debt Outstanding and Scheduled Debt Service, 1998-2007

(In billions of CFA franes, unless atherwise indicated)

\begin{tabular}{|c|c|c|c|c|c|c|c|c|c|}
\hline 1998 & 1999 & 2000 & $\begin{array}{l}200 \\
\text { Pro }\end{array}$ & 2002 & 2003 & 2004 & 2005 & 2006 & 2007 \\
\hline
\end{tabular}

\begin{tabular}{|c|c|c|c|c|c|c|c|c|c|c|}
\hline \multicolumn{11}{|l|}{ Total medium- and long-term } \\
\hline debt outstanding $1 /$ & $2,061.1$ & $2,302.5$ & $2,312.7$ & $1,980.5$ & $1,937.5$ & $1,871.4$ & $1,768.5$ & $1,659.2$ & $1,561.0$ & $1,473.2$ \\
\hline Of which: arrears & 227.2 & 472.8 & 0.0 & 59.9 & 0.0 & 0.0 & 0.0 & 0.0 & 0.0 & 0.0 \\
\hline Multilateral & 496.6 & 406.3 & 382.4 & 324.8 & 307.2 & 282.4 & 254.6 & 230.7 & 220.1 & 216.7 \\
\hline Of which: IMF & 64.4 & 52.6 & 64.0 & 55.6 & 45.6 & 36.1 & 20.8 & 5.5 & 0.0 & 0.0 \\
\hline AfDB & $\ldots$ & $\ldots$ & $\ldots$ & 69.2 & 41.9 & 39.9 & 36.3 & 34.4 & 31.0 & 27.9 \\
\hline IBRD & $\ldots$ & $\ldots$ & $\ldots$ & 15.0 & 9.1 & 8.7 & 6.8 & 5.2 & 4.9 & 4.6 \\
\hline Paris Club creditors & $1,498.6$ & $1,757.9$ & $1,846.2$ & $1,588.9$ & $1,385.4$ & $1,258.5$ & $1,112.4$ & 963.2 & 813.5 & 663.1 \\
\hline Other official creditors & 12.4 & 83.6 & 43.3 & 38.6 & 37.6 & 37.0 & 35.8 & 34.6 & 33.4 & 31.8 \\
\hline Commercial banks & 53.5 & 54.7 & 41.0 & 28.2 & 17.0 & 6.0 & -2.3 & -2.3 & -2.3 & -2.3 \\
\hline Gap financing & 0.0 & 0.0 & 0.0 & 0.0 & 190.2 & 287.5 & 367.9 & 433.0 & 496.2 & 563.8 \\
\hline Outstanding IMF credit & 64.4 & 52.6 & 64.0 & 55.6 & 45.6 & 36.1 & 20.8 & 5.5 & 0.0 & 0.0 \\
\hline Debt service due (including IMF) & 385.8 & 382.3 & 436.0 & 576.8 & 388.1 & 341.4 & 353.8 & 342.4 & 325.3 & 314.2 \\
\hline Principal & 205.0 & 209.5 & 249.0 & 305.8 & 242.3 & 213.7 & 233.3 & 230.9 & 222.9 & 217.8 \\
\hline Interest & 180.8 & 172.8 & 187.0 & 271.0 & 145.7 & 127.7 & 120.5 & 111.5 & 102.4 & 96.4 \\
\hline Multilateral (including the Fund) & 64.6 & 71.6 & 75.3 & 99.6 & 68.3 & 65.2 & 65.0 & 59.9 & 45.5 & 35.6 \\
\hline Of which: IMF & 16.8 & 17.5 & 9.7 & 10.9 & 12.6 & 12.1 & 17.4 & 16.7 & 6.1 & 0.0 \\
\hline Bilateral & 308.5 & 297.3 & 345.3 & 461.6 & 294.6 & 247.3 & 258.9 & 255.1 & 248.4 & 240.1 \\
\hline Paris Club pre-cutoff & 235.3 & 214.7 & 233.1 & 370.6 & 188.1 & 168.8 & 189.7 & 195.1 & 200.4 & 208.5 \\
\hline Never rescheduled & 1.7 & 7.4 & 6.4 & 7.8 & 3.5 & 1.3 & 1.2 & 1.2 & 0.4 & 0.3 \\
\hline Paris Club I (1987) & 6.3 & 6.0 & 5.7 & 5.7 & 0.0 & 0.0 & 0.0 & 0.0 & 0.0 & 0.0 \\
\hline Paris Club II (1988) & 27.4 & 6.0 & 5.9 & 5.7 & 0.0 & 0.0 & 0.0 & 0.0 & 0.0 & 0.0 \\
\hline Paris Club III (1989) & 75.6 & 61.7 & 56.0 & 32.1 & 0.0 & 0.0 & 0.0 & 0.0 & 0.0 & 0.0 \\
\hline Paris Club IV (1994) & 87.9 & 93.2 & 88.5 & 100.0 & 96.4 & 90.7 & 92.6 & 93.9 & 95.7 & 96.6 \\
\hline Paris Club V (1995) & 36.3 & 40.4 & 63.1 & 174.2 & 57.4 & 55.1 & 56.2 & 57,6 & 58.8 & 61.6 \\
\hline Paris Club VI (2000) & 0.0 & 0.0 & 7.5 & 45.1 & 30.7 & 21.7 & 39.7 & 42.4 & 45.6 & 50.0 \\
\hline Paris Club post-cutoff & 63.9 & 63.6 & 65.6 & 73.0 & 51.3 & 45.8 & 33.3 & 27.1 & 19.2 & 20.8 \\
\hline Nonguaranteed credit & $\ldots$ & $\ldots$ & 18.4 & 13.2 & 53.9 & 30.9 & 34.3 & 31.0 & 27.1 & 8.0 \\
\hline Non-Paris Club creditors & 3.8 & 3.1 & 5.6 & 4.9 & 1.4 & 0.8 & 1.6 & 1.9 & 1.6 & 2.7 \\
\hline Interest on arrears & 5.5 & 15.9 & 22.6 & 0.0 & 0.0 & 0.0 & 0.0 & 0.0 & 0.0 & 0.0 \\
\hline Provision for exchange rate losses & 0.0 & 0.0 & 0.0 & 0.0 & 8.0 & 5.5 & 5.0 & 6.6 & 6.5 & 10.0 \\
\hline Commercial banks & 12.6 & 13.3 & 15.4 & 15.5 & 12.7 & 11.9 & 8.5 & 0.0 & 0.0 & 0.0 \\
\hline Gap financing & 0.0 & 0.0 & 0.0 & 0.0 & 4.4 & 11.5 & 16.5 & 20.9 & 25.0 & 28.6 \\
\hline Debt cancellation & 19.0 & 18.0 & 17.0 & 17.0 & 0.0 & 0.0 & 0.0 & 0,0 & 0.0 & 0.0 \\
\hline Principal & 9.5 & 8.7 & 8.2 & 8.3 & 0.0 & 0.0 & 0.0 & 0.0 & 0.0 & 0.0 \\
\hline Interest & 9.5 & 9.3 & 8.8 & 8.7 & 0.0 & 0.0 & 0.0 & 0.0 & 0.0 & 0.0 \\
\hline Arrears & 0.0 & 0.0 & 0.0 & 0.0 & 0.0 & 0.0 & 0.0 & 0.0 & 0.0 & 0.0 \\
\hline Debt service due after debt & & & & & & & & & & \\
\hline tion (including IMF) & 366.8 & 364.3 & 419.0 & 559.8 & 388.1 & 341.4 & 353.8 & 342.4 & 325.3 & 314.2 \\
\hline Principal & 195.5 & 200.8 & 240.8 & 297.5 & 242.3 & 213.7 & 233.3 & 230.9 & 222.9 & 217.8 \\
\hline Interest & 171.3 & 163.5 & 178.2 & 262.3 & 145.7 & 127.7 & 120.5 & 111.5 & 102.4 & 96.4 \\
\hline Change in arrears (--reduction) & 227.2 & 245.6 & -482.2 & 59.9 & -59.9 & 0.0 & 0.0 & 0.0 & 0.0 & 0.0 \\
\hline Principal & 129.5 & 142.1 & -280.9 & 31.0 & -31.0 & 0.0 & 0.0 & 0.0 & 0.0 & 0.0 \\
\hline Interest & 97.8 & 103.5 & -201.3 & 28.9 & -28.9 & 0.0 & 0.0 & 0.0 & 0.0 & 0.0 \\
\hline
\end{tabular}


Table 7. Gabon : External Public Debt Outstanding and Scheduled Debt Service, 1998-2007

(In billions of CFA francs, unless otherwise indicated)

\begin{tabular}{|c|c|c|c|c|c|c|c|c|c|c|}
\hline & 1998 & 1999 & 2000 & 2001 & 2002 & 2003 & 2004 & 2005 & 2006 & 2007 \\
\hline & & & & $\begin{array}{r}\text { Prel. } \\
\text { est. }\end{array}$ & \multicolumn{6}{|c|}{ Projections } \\
\hline Debt rescheduling and deferral & 0.0 & 0.0 & 649.5 & 29.4 & 0.0 & 0.0 & 0.0 & 0.0 & 0.0 & 0.0 \\
\hline Debt service rescheduling & 0.0 & 0.0 & 0.0 & 0.0 & 0.0 & 0.0 & 0.0 & 0.0 & 0.0 & 0.0 \\
\hline Principal & 0.0 & 0.0 & 0.0 & 0.0 & 0.0 & 0.0 & 0.0 & 0.0 & 0.0 & 0.0 \\
\hline Interest & 0.0 & 0.0 & 0.0 & 0.0 & 0.0 & 0.0 & 0.0 & 0.0 & 0.0 & 0.0 \\
\hline Arrears rescheduling $2 f$ & 0.0 & 0.0 & 399.9 & 29.4 & 0.0 & 0.0 & 0.0 & 0.0 & 0.0 & 0.0 \\
\hline Principal & 0.0 & 0.0 & 250.8 & 25.1 & 0.0 & 0.0 & 0.0 & 0.0 & 0.0 & 0.0 \\
\hline Interest & 0.0 & 0.0 & 149.1 & 4.3 & 0.0 & 0.0 & 0.0 & 0.0 & 0.0 & 0.0 \\
\hline Deferred payments & 0.0 & 0.0 & 249.7 & 0.0 & 0.0 & 0.0 & 0.0 & 0.0 & 0.0 & 0.0 \\
\hline Principal & 0.0 & 0.0 & 105.8 & 0.0 & 0.0 & 0.0 & 0.0 & 0.0 & 0.0 & 0.0 \\
\hline Interest & 0.0 & 0.0 & 143.9 & 0.0 & 0.0 & 0.0 & 0.0 & 0.0 & 0.0 & 0.0 \\
\hline Debt service paid (inctuding IMF) & 139.5 & 118.7 & 251.7 & 470.4 & 448.0 & 341.4 & 353.8 & 342.4 & 325.3 & 314.2 \\
\hline Principal & 66.1 & 58.7 & 165.2 & 241.4 & 273.3 & 213.7 & 233.3 & 230.9 & 222.9 & 217.8 \\
\hline Interest & 73.5 & 60.0 & 86.5 & 229.0 & 174.7 & 127,7 & 120.5 & 111.5 & 102.4 & 96.4 \\
\hline \multicolumn{11}{|l|}{ Memorandum items: } \\
\hline \multicolumn{11}{|c|}{ External public debt/GDP (in percent) } \\
\hline Including IMF & 77.9 & 81.1 & 64.7 & 58.5 & 61.4 & 60.5 & 57.1 & 52.8 & 48.9 & 45.0 \\
\hline Excluding IMF & 75.5 & 79.2 & 62.9 & 56.8 & 59.9 & 59.3 & 56.4 & $\$ 2.6$ & 48.9 & 45.0 \\
\hline \multicolumn{11}{|c|}{ Extemal public debt/exports (in percent)3/ } \\
\hline Including IMF & 167.2 & 140.0 & 95.6 & 96.8 & 114.7 & 121.7 & 123.9 & 123.1 & 123.7 & 121.3 \\
\hline Excluding IMF & 159.6 & 135.8 & 92.9 & 94.1 & 112.0 & 119.3 & 122.5 & 122.7 & 123.7 & 121.3 \\
\hline \multicolumn{11}{|l|}{ Debt-service ratio $3 /$} \\
\hline Due (before relief) & 31.3 & 23.2 & 18.0 & 28.2 & 23.0 & 22.2 & 24.8 & 25.4 & 25.8 & 25.9 \\
\hline Principal & 16.6 & 12.7 & 10.3 & 14.9 & 14.3 & 13.9 & 16.3 & 17.1 & 17.7 & 17.9 \\
\hline Interest & 14.7 & 10.5 & 7.7 & 13.2 & 8.6 & 8.3 & 8.4 & 8.3 & 8.1 & 7.9 \\
\hline Paid & 11.3 & 7.2 & 10.4 & 23.0 & 26.5 & 22.2 & 24.8 & 25.4 & 25.8 & 25.9 \\
\hline Principal & 5.4 & 3.6 & 6.8 & 11.8 & 16.2 & 13.9 & 16.3 & 17.1 & 17.7 & 17.9 \\
\hline Interest & 6.0 & 3.6 & 3.6 & 11.2 & 10.3 & 8.3 & 8.4 & 8.3 & 8.1 & 7.9 \\
\hline \multicolumn{11}{|l|}{$\begin{array}{l}\text { Debt service/goverument revenue } \\
\quad \text { (in percent) } 4\end{array}$} \\
\hline Due (before relief) & 42.3 & 47.0 & 36.1 & 48.5 & 39.3 & 36.4 & 39.3 & 38.7 & 38.1 & 37.5 \\
\hline Paid & 15.3 & 14.6 & 20.8 & 39.5 & 45.3 & 36.4 & 39.3 & 38.7 & 38.1 & 37.5 \\
\hline \multicolumn{11}{|c|}{ Debt service/non-oil GDP (in percent) } \\
\hline Due (before relief) & 20.3 & 21.6 & 23.7 & 29.8 & 18.7 & $\$ 5.7$ & 15.4 & 14.0 & 12.5 & 11.4 \\
\hline Paid & 7.3 & 6.7 & 13.7 & 24.3 & 21.5 & 15.7 & 15.4 & 14.0 & 12.5 & 11.4 \\
\hline
\end{tabular}

Sources: Gabonesc authorities; and staff estimates and projections.

1/ End-of-period data, excluding publicly guaranteed debt.

2/ Arrears to non-Paris Club creditors under negotiation at end-2001.

$3 /$ In percent of exports of goods and nonfactor services.

4/ In percent of government revenue, excluding grants. 
Table 8. Gabon: Medium-Term Balance of Payments Outlook, 2000-07

(In billions of CFA francs, unless otherwise indicated)

2000

\begin{tabular}{rllllll}
2001 & 2002 & 2003 & 2004 & 2005 & 2006 & 2007 \\
\cline { 2 - 5 } \\
$\begin{array}{r}\text { Prel. } \\
\text { est }\end{array}$
\end{tabular}

Baseline scenario

Oil exports (f.o.b.)

Non-oil exports (f.o.b.)

External curtent account balance/GDP (in percent)

Overall budget balance (commitment basis)

Overall budget balance/GDP (in percent)

Financing gap

Financing gap/GDP (in percent)

$\begin{array}{rrrrrrrr}1,827.8 & 1,509.1 & 1,128.8 & 955.9 & 821.0 & 711.7 & 597.3 & 517.4 \\ 457.4 & 420.1 & 439.4 & 456.5 & 475.3 & 497.2 & 522.0 & 549.9 \\ 3.2 & -1.1 & -4.8 & -5.1 & -6.0 & -5.6 & -6.1 & -5.1 \\ 421.5 & 255.9 & 156.7 & 187.4 & 181.2 & 184.0 & 166.4 & 153.1 \\ 11.8 & 7.6 & 5.0 & 6.1 & 5.8 & 5.9 & 5.2 & 4.7 \\ 0.0 & 0.0 & 190.2 & 97.3 & 80.4 & 65.1 & 63.2 & 67.5 \\ 0.0 & 0.0 & 6.0 & 3.1 & 2.6 & 2.1 & 2.0 & 2.1\end{array}$

Change compared with baseline

Scenario A: US\$1 per barrel lower each year, 2002-07

Current account (percentage points of GDP)

Financing gap (billions of CFA franes)

Financing gap (percentage points of GDP)

$\begin{array}{rrrrrrrr}0.0 & 0.0 & -1.2 & -1.2 & -1.1 & -0.5 & -0.8 & -0.7 \\ 0.0 & 0.0 & 30.6 & 36.9 & 34.2 & 20.8 & 30.2 & 29.6 \\ 0.0 & 0.0 & 1.1 & 1.3 & 1.2 & 0.7 & 1.0 & 0.9\end{array}$

Scenario B: 10 percent lower oil production each year, 2002-07

Current account (percentage points of GDP)

Financing gap (billions of CFA francs)

Financing gap (percentage points of GDP)

$\begin{array}{rrrrrrrr}0.0 & 0.0 & -1.7 & -2.0 & -1.8 & -1.1 & -1.3 & -1.1 \\ 0.0 & 0.0 & 40.9 & 51.8 & 47.4 & 33.1 & 41.1 & 39.1 \\ 0.0 & 0.0 & 1.6 & 1.8 & 1.6 & 1.2 & 1.3 & 1.2\end{array}$

Scenario C: Lower growth of non-oil exports $1 /$

Current account (percentage points of GDP)

Financing gap (billions of CFA francs)

Financing gap (percentage points of GDP)

$\begin{array}{rrrrrrrr}0.0 & 0.0 & -0.1 & -0.3 & -0.4 & -0.5 & -0.6 & -0.9 \\ 0.0 & 0.0 & -2.5 & 2.3 & 2.8 & 3.3 & 4.0 & 5.3 \\ 0.0 & 0.0 & -0.1 & 0.1 & 0.1 & 0.1 & 0.1 & 0.2\end{array}$

Sources: Gabonese authorities; and staff estimates and projections.

1/ Assumes 1 percentage point lower growth rate of non-oil exports each year. 
Table 9. Gabon: Income and Social Indicators, 1970-99

\begin{tabular}{|c|c|c|c|c|c|}
\hline \multirow{3}{*}{ Population } & \multicolumn{3}{|c|}{ Latest Single Year } & \multicolumn{2}{|c|}{ Same Region/Income Group } \\
\hline & \multirow[t]{2}{*}{$1970-75$} & \multicolumn{2}{|c|}{$1980-851993-99$} & \multirow[t]{2}{*}{$\begin{array}{l}\text { Sub-Saharar } \\
\text { Africa }\end{array}$} & \multirow[t]{2}{*}{$\begin{array}{l}\text { Upper-middle } \\
\text { income }\end{array}$} \\
\hline & & & & & \\
\hline Total population, midyear (millions) & 0.6 & 0.8 & 1.2 & 659 & 647 \\
\hline Growth rate (antrual average, in percent) & 3.3 & 3.3 & 2.4 & 2.6 & 1.3 \\
\hline Urban population (in percent of population) & 40 & 5.2 & 81 & 34 & 76 \\
\hline Total fertility rate (births per woman) & 4.3 & 4.5 & 5.1 & 5.3 & 2.7 \\
\hline \multicolumn{6}{|l|}{ Poverty $1 /$} \\
\hline Poverty incidence $2 /$ & $683 /$ & $\ldots$ & 62 & $\ldots$ & .. \\
\hline \multicolumn{6}{|l|}{ Income } \\
\hline GNP per capita (U.S. dollars) & 3,100 & 3,900 & 3,877 & 538 & 5,407 \\
\hline Consumer price index $(1995=100)$ & 26 & 76 & 107.5 & 131 & 122 \\
\hline Food price index $(1995=100)$ & $\ldots$ & 76 & 107 & 130.5 & $\ldots$ \\
\hline \multicolumn{6}{|l|}{ Social indicators } \\
\hline \multicolumn{6}{|l|}{ Public expenditure } \\
\hline Health (in percent of GDP) & $\ldots$ & $\ldots$ & 3.1 & 3.99 & 5.48 \\
\hline Education (in percent of GNP) & 2.1 & 5.0 & 2.9 & 4.1 & 5.0 \\
\hline \multicolumn{6}{|l|}{$\begin{array}{l}\text { Gross school enrollment rates } \\
\text { (in percent of age group) }\end{array}$} \\
\hline Primary & $\ldots$ & 172 & 162 & 78 & 107 \\
\hline Secondary & $\ldots$ & 43 & 56 & 25 & 64 \\
\hline Tertiary & $\cdots$ & 6 & 8 & 3 & 14 \\
\hline \multicolumn{6}{|l|}{ Access to safe water (in percent of population) } \\
\hline Total & $\cdots$ & 58 & 67 & $\cdots$ & $\cdots$ \\
\hline Urban & $\ldots$ & 75 & 80 & $\ldots$ & $\ldots$ \\
\hline Rural & $\ldots$ & 34 & 30 & $\ldots$ & $\ldots$ \\
\hline \multicolumn{6}{|l|}{$\begin{array}{l}\text { Immunization rate (in percent of children under } \\
12 \text { months) }\end{array}$} \\
\hline Measles & $\ldots$ & 58 & 30 & 57 & 78 \\
\hline DPT & $\cdots$ & 24 & 31 & 59 & 75 \\
\hline \multicolumn{6}{|l|}{ Life expectancy at birth (years) } \\
\hline Total & 45 & 49 & 53 & 47 & 66 \\
\hline Male & 43 & 47 & 51 & 46 & 65 \\
\hline Female & 47 & 51 & 54 & 48 & 69 \\
\hline \multicolumn{6}{|l|}{ Mortality } \\
\hline Infant (per 1,000 live births) & 132 & 112 & 84 & 92 & 54 \\
\hline Under 5 (per 1,000 live births) & 232 & 194 & 133 & 161 & 78 \\
\hline \multicolumn{6}{|l|}{ Adult (15-59) } \\
\hline Male (per 1,000 population) & 521 & 474 & 386 & 499 & 221 \\
\hline Female (per 1,000 population) & 421 & 387 & 344 & 453 & 170 \\
\hline Maternal (per 100,000 live births) & $\ldots$ & 600 & $\ldots$ & $\ldots$ & ... \\
\hline
\end{tabular}

Source: World Bank, World Development Indicators, 2001.

1/ Poverty data from Gabon's interim poverty reduction strategy paper.

$2 /$ Defined as the share of the population with per capita consumption of less than two-thirds of the national average.

3/ As of 1960. 
Table 10. Gabon: Prior Actions and Structural Performance Criteria for 2000-01

\begin{tabular}{lll}
\hline & Date-Initial Program & Date- \\
Conditions and Structural Measures & Revised & Implementation Status \\
& Program & \\
& EBS/01/ \\
& 56 Sup. \\
\hline
\end{tabular}

Conditions for presentation of a request to use Fund resaurces (October 2000)

Macroeconomic performance and budget execution on a disbursements basis, for the period January-June 2000 , in accordance with the government's economic program for 2000 .

Adoption of a Supptementary Budget Law for Prior action 2000 , consistent with the revised macroeconomic framework for 2000 .

Introduction of the cash-flow management system.

Publication of an audit of the central government's finances for 1997 and 1998, and the audit of the domestic public debt, carried out in December 1999.

Post and Telecommunications Office (OPT): adoption by ordinance of the laws on the new legal and regulatory framework.

Ciments du Gabon; choice of contractor.

\section{Conditions for consideration by the} Executive Board of the documentation for the first and second program reviews under the Stand-By Arrangement

Appointment of the OPT liquidator and the provisional managers for Gabon

Postes and Gabon Télécom.

Adoption by the government and submission to parliament of the draft anticorruption law ("against illegitimate enrichment") and the draft law on the National Commission Against Mllegitimate Enrichment (CNAC).

Adoption of a timetable for preparation of Prior action the Code of Ethics for the Gabonese government.

Prior action

\section{All Completed}

Completed on August 4, 2000

Adopted on July 27, 2000

Completed on May 31, 2000

Completed on September 5, 2000

Completed on February 17, 2000

Completed on July 13,2000

Completed on June 20, 2001

Completed on March 27, 2001

Completed in February 2001 
Table 10. Gabon: Prior Actions and Structural Performance Criteria for 2000-01

Conditions and Structural Measures

\begin{tabular}{|c|c|c|}
\hline Date-Initial Program & $\begin{array}{l}\text { Date- } \\
\text { Revised } \\
\text { Program } \\
\text { EBS/01/ } \\
56 \text { Sup. }\end{array}$ & Implementation Status \\
\hline
\end{tabular}

\section{Performance criteria}

Government finance

Introduction of the integrated information system (CRYSTAL):

- Beginning of parallel testing phase for all modules.

- Beginning of use of the full computerized information system.

- Commitment not to create any special accounts or special funds outside the budget.

\section{Administrative reform}

Effective introduction of a civil service personnel and payroll management system based on a common operational file in the Ministry of Economy, Finance, Budget and Privatization, and the Ministry of Civil Service, Administrative Reform, and Modernization of the State.

\section{Government enterprise sector}

Selection of the merchant bank for implementing the privatization of Gabon Télecom.

Invitation to bid in the privatization of Gabon Télécom

Selection of provisional contractor for Gabon Télécom.

Selection of provisional contractor for the privatization of AGROGABON.

Invitation to bid in the privatization of HEVEGAB.

Selection of provisional contractor for the privatization of HEVEGAB.
March 31, 2001

September 30, 2001
October 31, 2000

January 31,2001

Throughout the period of the Stand-By

Arrangement

December 31, 2001
Completed

Completed

Met

Not met; delayed to early 2003
March 31, 2001

June 30,2001

December 31, 2000

March $31,2002^{1}$
Completed

Not completed; changed to a structural benchmark for endDecember $2001^{\mathrm{L}}$

Deferred to 2002; target date now out of reach

Not completed, because two rounds of bids were unsuccessful; a three-year management contract signed in June 2001

Completed, but unsuccessfully, in November 2000

Changed to a structural benchmark for March 31, 2002; ${ }^{1}$ target date now out of reach

Completed with a delay in March 2001

\section{Governance}

Adoption by the government and presentation December 31, 2000 to parliament of a draft anticorruption law.

\footnotetext{
The structural performance criterion was modified at the time of the first and second reviews on July 13, 2001.
} 
Table 11. Gabon: Structural Benchmarks for 2000-01

$\begin{array}{ccc}\text { Structural Measures } & \begin{array}{c}\text { Date-Initial } \\ \text { Program }\end{array} & \begin{array}{c}\text { Date-Revised } \\ \text { Program } \\ \text { EBS/01/56 Sup. }\end{array}\end{array}$ Implementation Status

Public finance

1. Framework letter for preparation of the Budget Law for 2001 in line with the macroeconomic program for 2001.

2. Preparatory work on transforming the current land taxation system into a land tax in the context of the land tenure reform.

3. Discussion of the draft Budget Appropriations Act for 2001 with IMF staff prior to its submission to parliament

4. Annual review of public investment projects with assistance from the World Bank.

\section{Government enterprise sector}

1. Post and Telecommunications Office (OPT)

- Separation of the OPT into two distinct entities: Gabon Postes and Gabon Télécom.

- Appointment of the liquidator for the OPT and of provisional managers for Gabon

Postes and Gabon Télécom.

- Definitive allocation of OPT assets and personnel to the new entities, Gabon Postes and Gabon Télécom. ${ }^{1}$

- Invitation to bid for the privatization of Gabon Tẻlécom. ${ }^{1}$

\section{AGROGABON}

- Invitation to bid in the privatization (in the form of sale of assets, plantation operation and concessions).
July 31,2000

Completed

Second half of 2000

September/

October 2000

June/July 2001

September 30 ,

2000

September 30, 2000

December 31, During 2002 2001

September 30, 2000

September 30 , 2000
Completed with a delay (May, 2001) Completed with a delay (June, 2001)

Deferred; opening balance sheets not ready

December 31, 2001

Delayed to 2002 , awaiting effective liquidation and restructuring

Bid launched in May 2000 , and again in January 2001, but unsuccessfully. Threeyear management contract signed in July 2001

December 31, Delayed to May 2002 2001

March 31, 2002 Delayed: new target date mid-2002

Completed behind schedule in February 2001 
Table 11, Gabon; Structural Benchmarks for 2000-01

\begin{tabular}{cccc}
\hline Structural Measures & $\begin{array}{c}\text { Date-Initial } \\
\text { Program }\end{array}$ & $\begin{array}{c}\text { Date-Revised } \\
\text { Program } \\
\text { EBS/01/56 Sup. }\end{array}$ & Implementation Status \\
& & \\
\hline
\end{tabular}

- Invitation to bid in the privatization.

- Selection of provisional contractor.

\section{Air Gabon}

- Adoption by the Interministerial Privatization Committee of the privatization arrangement based on the restructuring plan drawn up on June $30,2000$.

- Implementation of the privatization arrangement.

- Decision on the privatization arrangement.

- Invitation to bid in the privatization.

6. Other public enterprises

- SMAG, PIZOLUB-SOGAFUTS, SNAT, AGRIPOG: divestiture of the State's share.'

- National Navigation Company (CNI)

- Adoption of a privatization timetable

- Invitation to bid. ${ }^{1}$

- SOGADEL and Gabon Informatique: initiate court-ordered liquidation.

- SIAEB: liquidation.

- Gabon Office of Ports and Roads (OPRAG) $/$ Port of Owendo.

- Finalization of strategic study.

- Invitation to bid for the Owendo port concession.

- Selection of strategic investor. ${ }^{1}$
December 31, 2000

December 31 , 2000

June 30, 2001

December 31, 2000

March 31, 2001

December 2001

January 31,

2002

December 31, During 2001 2000

December 31, 2000

March 31, 2001

Decer

December 31 , 2000

December 31, 2001

June 30, 2001.
Not completed; new management contract signed with foreign firm in September 2001

Not completed; technical assistance contract signed with external partner

Deferred and redefined

Nat met

Deferred

Not completed

Not completed; however, a consultant has been recruited to conduct a study

Deferred

Completed. Decision to liquidate taken, but implementation delayed Not completed. Decision to liquidate taken, but implementation delayed

Not completed; unsuccessful bid for consultant

Deferred

December 31, Not completed 2001. 
Table 11. Gabon: Structural Benchmarks for 2000-01

\begin{tabular}{cccc}
\hline Structural Measures & $\begin{array}{c}\text { Date-Initial } \\
\text { Program }\end{array}$ & $\begin{array}{c}\text { Date-Revised } \\
\text { Program } \\
\text { EBS } / 01 / 56 \text { Sup. }\end{array}$ & Implementation Status \\
\hline
\end{tabular}

\section{Reform of the legal and regulatory framework}

1. Forestry and timber sector: resubmission of the Forestry Code to Parliament.

2. Labor: resubmission of the Labor Code to Parliament.

3. Commerce

- Introduction of a single window for all formalities related to establishing a business.

- Preparation by the government of a draft Commercial Code, in line with the Investment Charter and the Uniform Acts of OHADA.

4. Land tenure reform

- Reform of existing system, including the introduction of a land tax registry.

- Adoption of measures to facilitate access to land ownership.

\section{Administrative reform/civil service reform}

- Harmonization of civil service roster and payroll roster.

- Adoption by the government and submission to parliament of a new General Statute of the civil service, a new Specific Statute for regular government employees, and a new Specific Statute for contractual government employees.

- Strict observance of objective criteria in applying Article 23 of the General Statute of the Civil Service.

\section{Governance}

- Completion of the financial audit of the oil companies for fiscal years 1999 and 2000 by the Joint Commission (Ministry of Finance and Ministry of Mining). ${ }^{-1}$
December 31 , 2000

July 31,2000

Completed; Forestry

Code adopted by

Parliament in

November 2001

Completed; Code promulgated in October 2000

September 30, 2000

December 31, 2000

Not completed; structure not yet functional

Little progress

September 30, 2001

September 30, 2001

March 31, 2001

In progress, awaiting new organizational charts. Deferred to 2002

June 30, 2001 Not completed. Now expected for March 2002

Met

Throughout the period of the Stand-By

Arrangement
Not completed

Not completed
End-September 2001
Not completed. Audit completed for three minor companies only 
Table 11. Gabon: Structural Benchmarks for 2000-01

\begin{tabular}{|c|c|c|c|}
\hline Structural Measures & $\begin{array}{c}\text { Date-Initial } \\
\text { Program }\end{array}$ & $\begin{array}{l}\text { Date-Revised } \\
\text { Program } \\
\text { EBS/01/56 Sup. }\end{array}$ & Implementation Status \\
\hline $\begin{array}{l}\text { - Presentation to Parliament of a Code of } \\
\text { Ethics for the Gabonese central } \\
\text { administration, including the members of the } \\
\text { government. }{ }^{-1}\end{array}$ & & $\begin{array}{l}\text { December 31, } \\
2001\end{array}$ & $\begin{array}{l}\text { Delayed. The code was } \\
\text { reviewed by the } \\
\text { Commission for } \\
\text { administrative } \\
\text { reform(CIRA) in mid- } \\
\text { February } 2002 \text {; awaits } \\
\text { adoption by government }\end{array}$ \\
\hline
\end{tabular}

\section{Reform of the social security system}

- Tum to private management of the hospital branch of the National Social Security Fund (CNSS) :

- Study of the hospital branch; and

- Adoption of a timetable for the concession of management to independent operators.

\section{Foreign trade regime}

- Reduction in the maximum common external tariff applicable to imports.

\section{Poverty reduction}

- Publication of the provisional school allocation and health allocation maps (based on existing data) and completion of a study of unit costs in primary and secondary education.

- Finalization and publication of the results of the population and health survey.

- Adoption of an overall poverty reduction strategy.

\section{Statistics}

- Strengthening of the unit responsible for preparing balance of payments statistics, and especially those of the oil sector.

- Submission to parliament of the revised Statistics Law

- Adherence to the General Data Dissemination System (GDDS).
September 30,

2001

December 31, 2001

In line with

CEMAC

schedule

March 31, 2001

June 30, 2001

December 31, 2001

Throughout the period of the

Stand-By

Arrangement

September 30, 2001

December 31, 2001
Preliminary report completed at end-2001 Delayed

Under consideration

Almost completed

Completed

Not completed. Preliminary draft interim PRSP produced

Not met

In progress; expected for the second half of 2002

Intention to participate declared in November 2001

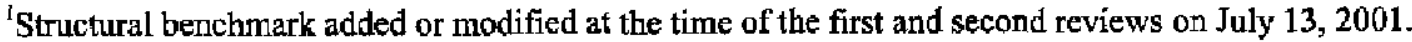


Gabon: Relations with the Fund

(As of January 31, 2002)

I. Membership Status: Joined: 09/10/1963; Article VIII

II. General Resources Account:

Quotas

Fund Holdings of Currency

Reserve position in Fund

III. SDR Department:

Net cumulative allocation

Holdings

IV. Outstanding Purchases and Loans:

Stand-by arrangements

Extended arrangements
SDR Million

154.30

217.77

0.18

SDR Million

14.09

0.56

SDR Million

13.22

46.42
\%Quota

100.00

138.54

0.12

\%Allocation

100.00

4.01

\%Quota

8.57

30.09

v. Latest Financial Arrangements:

$$
\text { Approval Expiration }
$$

Type

Stand-by

EFF

Stand-by

\section{Date} $10 / 23 / 2000$

$11 / 08 / 1995$

03/30/1994
Date

04/22/2002

03/07/1999

$03 / 29 / 1995$
Amount

Approved

(SDR Million)

92.58

110.30

38.60
Amount Drawn

(SDR Million)

13.22

60.67

38.60

V. Projected Obligations to Fund (SDR Million; based on existing use of resources and present holdings of SDRs):

\begin{tabular}{|c|c|c|c|c|c|c|}
\hline & \multirow[t]{2}{*}{ Overdue } & \multicolumn{5}{|c|}{ Forthcoming } \\
\hline & & $\underline{2002}$ & $\underline{2003}$ & 2004 & $\underline{2005}$ & $\underline{2006}$ \\
\hline Principal & 0 & 10.1 & 10.1 & 16.7 & 16.7 & 4.6 \\
\hline Charges/Interest & $\underline{0}$ & 1.9 & 1.6 & 1.3 & 0.8 & 0.5 \\
\hline Total & $\overline{0}$ & 12.0 & 11.7 & 18.0 & 17.5 & 5.1 \\
\hline
\end{tabular}




\section{Safeguards Assessments:}

A Stage One safeguards assessment of the BEAC was completed on March 29, 2001. The assessment concluded that high risks may exist in financial-reporting practices and internal control and a Stage Two (on-site) assessment was completed on July 25, 2001. The staff findings and recommendations are reported in the Bank of Central African States Report on the Stage Two (On-Site) Safeguards Assessment Mission (see Appendix III).

\section{Exchange Rate Arrangement:}

Gabon's currency is the CFA franc, which is pegged to the euro at a fixed rate of CFAF $655.957=€ 1$.

\section{Last Article IV Consultation:}

(a) Consultations with Gabon are on the standard 12-month cycle.

(b) The last consultation discussions were initiated in Libreville in March 2000, and completed in Washington, D.C. in August 2000. The consultation was concluded by the Executive Board on October 23, 2000 (SUR/00/101; 10/25/00).

\section{FSAP Participation:}

FSAP mission in Libreville and Yaoundé in June and July 2001. FSSA report to be issued shortly.

XI. Technical Assistance:

Subject

Review of budgetary

procedures and expenditure control

Value-added tax (VAT)

administration issues

Tax administration and introduction of VAT

Multitopic statistics mission

$\begin{array}{lll}\text { Department } & \text { Staff Member } & \text { Date } \\ \text { FAD } & \text { Mr. Bouley } & \text { November 2000 } \\ & \text { Mr. Toussaint } & \text { May 2000 } \\ & \text { Mr. Toussaint } & \text { April 1999 } \\ & \text { Mr. Garamfalvi } & \text { April 1995 }\end{array}$

FAD Mr. Grandcolas August 1997

FAD Mr. Grandcolas June 1996

Mr. Grandcolas November 1995

STA

Mr. Raymond

April 1999

Mr. Raymond

) May 1998

Ms. Doizé

Mr. Habanananda )

Mr. Le Marois

Ms. Wesseling )

Mr. Ebrahim-zadeh Since

\section{Resident Representative:}




\section{Gabon: Relations with the World Bank}

(As of January 25, 2002)

1. Following the adjustment of the parity of the CFA franc on January 12, 1994, a quick-disbursing economic recovery loan of US\$30 million to support measures accompanying the devaluation was approved by the Board on June 21, 1994 and fuily disbursed. In addition, a transport and urban sector technical assistance loan of US\$5.2 million, which became effective on June 23, 1995, provided support for the government in defining sectoral strategies and financed the activities of the consultant selected to assist in the privatization of railway operations.

2. In June 1997, the Bank approved a privatization and regulatory capacity-building technical assistance loan (Privatization Program Support Project) in an amount equivalent to US\$10 million, which complements the assistance of other donors participating in the financing of the project. On August 18, 1998, the Bank approved an Institutional Development Facility (IDF) grant of US\$55,000 to support the National Capacity Building Secretariat. An urban learning and innovation loan in an amount equivalent to US\$5 million was approved on August 24, 1998; its purpose is to help test new procurement methods, support the implementation of pilot urban works in poor urban neighborhoods, and conduct urban public expenditure reviews.

3. In June 1992, the Bank approved a forestry/environment investment loan for US\$22.5 million, conditional on the formulation of an environmentally sound legislative framework for the exploitation of forestry resources. The loan was declared effective in September 1993 and expired in June 2001. A follow-up Forestry-Environment Program is being prepared for Board approval in FY 2003.

4. A two-year Country Assistance Strategy (CAS), which includes a variety of nonlending services and two lending operations in 2000 , was considered by the Board on October 15,1998 . With the support of a US $\$ 750,000$ grant from the Japanese government, several studies have been carried-out in key poverty reduction sectors (health, education, and rural development).

5. In February 1996, as part of a pilot decentralization experiment, the Bank established a liaison office in Libreville, staffed by a resident economist. Based on the constructive and favorable experience, the Bank created a resident mission in Libreville in September 1999.

6. The Bank is considering assisting the government in the design and financing of a transport sector operation.

7. A Poverty Assessment (PA), initiated in late 1994, was finalized in March 1997 and discussed with a broad range of Gabonese stakeholders in July 1997. The main conclusion of the report is that the relative inefficiency and low quality of public expenditures, particularly in the social sectors, constitute major impediments to poverty alleviation. 
8. Gabon signed the Multilateral Investment Guarantee Agency (MIGA) Convention on April 15, 1994.

9. The involvement of the International Finance Corporation (IFC) in Gabon has shifted from extractive to transformation activities. The IFC has no outstanding investments, and its oil and manganese development loans bave been fully repaid. The IFC intends to intensify promotional activities, targeting small and medium-sized Gabonese companies involved directly or indirectly in the oil and mining sectors--such as construction and metal worksas well as transport and service companies. The government appointed the IFC as its financial advisor in the privatization of the electricity and water companies (SEEG), which was successfully completed in June 1997 . The IFC recently opened a subregional office in Douala, Cameroon, from which it plans to cover Gabon. 
Gabon: Relations with the World Bank Group

(As of January 25, 2002)

Summary of IBRD and IDA Lending Operations (in millions of U.S. dollars)

Closed credits (17)

Approved

Of which:

Amount

Undisbursed

Disbursing credits ( 3$)^{1}$

Forestry/environment (1992)

Privatization and regulatory capacity building technical assistance (1997)

189.5

Urban learning and innovation infrastructure project (1998)

22.5

0.6

10.0

2.0

Original principal

5.0

3.7

Cancellations

227.0

Disbursed

Undisbursed

215.0

Repaid

6.3

Borrower's obligation

158.8

54.9

Memorandum items:

Anmual IBRD/IDA operations

FY 1984

FY 1985

FY 1986

FY 1987

FY 1988

FY 1989

FY 1990

FY 1991

FY 1992

FY 1993

FY 1994

FY 1995

FY 1996

FY 1997

FY 1998

FY 1999

FY 2000

FY 2001
Gross Disbursements

67.0

0.0

0.0

0.0

0.0

20.0

29.8

12.1

9.0

7.3

5.3

33.4

3.7

2.8

5.0

4.9

10.8

3.9

215.0
Repayments

56.7

1.8

1.4

1.2

1.4

1.6

1.0

1.1

1.2

7.3

7.3

11.9

11.5

10.7

9.9

9.5

17.3

6.0

158.8

Total

Source: World Bank.

${ }^{1}$ In parentheses year of approval. 


\section{Bank of Central African States: Safeguards Assessment}

\section{Introduction}

The Bank of Central African States (BEAC) is the common central bank of the Central African States, which includes Gabon. A Stage Two (on site) safeguards assessment of the $B E A C$ proposed specific remedies to alleviate vulnerabilities that were identified by staff. The authorities have committed to implement most of the proposed remedies, as described in the following sections.

\section{Safeguards areas and main remedies}

The external audit mechanism: The auditing function and the quality control procedures of the external auditor are adequate. The safeguards assessment proposed that (i) the external auditor refer explicitly to the international standards of auditing (ISA) in its opinion; (ii) the external auditor become more cognizant of the accounting rules applicable to the recording of Fund's balances; and (iii) the BEAC should include the audit opinion in the annual publication of the financial statements. The management of the BEAC has agreed to implement these actions for the FY 2002 accounts.

Legal structure and independence: The legislation governing BEAC is adequate.

Financial reporting: The monthly statements of the bank's financial position are not published in any form and the December 31,2000 audited financial statements were not published in a timely manner. The staff recommended that the BEAC (i) enhance the readability and the credibility of the published annual accounts by including detailed explanatory notes on the accounting methods followed, and if these methods referred explicitly to a generally accepted accounting framework; (ii) adopt International Accounting Standards; and (iii) change the accounting of some of its operations with the Fund, especially with regard to the revaluation of the $\mathrm{MMF}$ accounts. The management of the $\mathrm{BEAC}$ has agreed to implement these recommendations by FY 2002.

Internal andit mechanism: The quality of the personnel, the rigorous methods followed for the audit of branches, the training program in place, and the risk assessment methods in place are satisfactory. However, certain weaknesses remain and staff recommended that the BEAC (i) establish a charter for the Internal Audit Department (IAD); (ii) expand the audit scope and coverage of IAD to include activities at headquarters; (iii) prepare an annual rolling multi-year audit program describing risk assessment, activities scheduled, and staffing and financial resources required; and (iv) increase the number of qualified staff.

In its response to the Stage Two report, the management of the BEAC has specifically agreed to expand the scope and coverage of the audit department, and increase the number of qualified staff. A charter for the audit department will also be prepared, with the assistance of Fund staff, which will provide the BEAC with the relevant documentation. A gradual 
implementation of these recommendations should be completed by end-2002. The management of the BEAC did not specifically cover in its answer to the report the recommendation related to the risk-based rolling multi-year audit program.

The system of internal controls: On the whole, the risks are relatively well captured, although uncertainties exist because of insufficient a posteriori controls exercised on some activities at headquarters. The bank has a codified system of rules, selects its personnel carefully, maintains segregation of duties in the branches, and has recently increased resources for control purposes. Nevertheless, the staff recommended that the BEAC (i) strengthen the coordination among the audit bodies; (ii) examine in depth the segregation of duties at headquarters; and (iii) put in place a more systematic follow-up of all recommendations made by the external auditor to allow the Governor and the Board of Directors to better exercise their oversight responsibilities.

In its response to the Stage Two report, the management of the BEAC has agreed to establish an audit committee by 2002 . Regarding the proposed segregation of duties, management noted that an internal assessment was under way, but that for budgetary reasons a formal audit cannot be undertaken before end- 2002 .

Regarding late payments of Fund obligations, which was an issue for all of the BEAC's member countries at some time in the last three years, the staff concluded that, while the BEAC's own payment procedures and related management controls in this area are functioning adequately, procedures should be modified with respect to BEAC's relations with member countries. The staff recommended that the BEAC should repay the Fund directly using its own resources for those countries with borrowing capacity with the central bank; for countries facing fiscal difficulties, staff recommended that they at least maintain sufficient borrowing capacity with the BEAC to repay IMF obligations falling due within the next year. In its answer to the Stage Two Report, the management of the BEAC did not follow the mission's recommendation that the BEAC should repay the Fund directly. The management also commented that apart from direct statutory advances to Treasuries, the BEAC could not grant loans to member countries. 


\section{Gabon: Statistical Issues}

The available economic database of Gabon is fairly comprehensive. Data are generally compiled consistent with international standards, but consistency between sectors is poor, raising questions about the quality of the data. Detailed economic and financial statistics, including long historical time series, are published in the Tendances de l'Economie, issued on a semiannual basis by the General Directorate of Statistics and Economic Studies (DGSEE) of the Ministry of Planning; more recent sectoral developments are described in detail in the Tableau de Bord de l'Economie, issued on a quarterly basis by the General Directorate for the Economy (DGE) of the Ministry of Economy, Finance, Budget, and Privatization.

An Interinstitutional Statistics Committee to improve macroeconomic data gathering, compilation, and dissemination was established in 1999, in response to STA and FAD recommendations. Following the detection of questionable accounting practices by audits of central government finances and domestic public debt in 1998, the fiscal data, national accounts, and balance of payments statistics for 1997-98 have been revised. As a result, there have been delays in reporting consistent data to the Fund.

Gabon has already nominated a General Data Dissemination System (GDDS) coordinator and has recently submitted draft metadata through its participation in the regional GDDS workshop that was held in Yaoundé in January-February 2002. Gabon's GDDS participation process would be completed with the posting of the GDDS metadata on the Fund's Dissemination Standards Bulletin Board, which is expected to take place in Spring 2002.

\section{National accounts}

Annual national accounts data were revised and updated for the period 1985-96, and the base for the calculation of aggregates at constant prices was changed from 1989 to 1991. These data were prepared by the DGSEE. Provisional estimates of national accounts data for the 1997-98 period have been prepared by the Interinstitutional Statistics Committee and the DGE, but have not yet been finalized. The coverage of developments in the oil and other key export sectors is based on a range of indicators that may not fully capture the profits generated by these sectors. Despite recent improvements in collecting and processing oil sector statistics, significant inconsistencies remain between national accounts and the balance of payments statistics. In addition, more frequent household surveys are required to improve the quality and quantity of data available on income distribution and consumption. The staff and the authorities are working closely to establish a more consistent database.

\section{Employment and unemployment}

Detailed annual data on employment are available for all sectors of the economy until 1997, including a breakdown of employment between the public and private sectors. However, data on unemployment and the total labor force are not systematically available. 


\section{Prices}

Monthly consumer price indices for African households and middle-income households are available only for the capital city of Libreville. These indices are based on an outdated family expenditure survey of 1968-69 and attach a large weight to prices of food and basic consumer goods. The "new" household budget survey of 1993 should allow for the development of a more representative index, when it is introduced.

\section{Government accounts}

A multisector statistical mission, which covered government finance statistics, visited Gabon in May-June 1998. Furthermore, the review of budgetary procedures and expenditure control in Gabon completed by a FAD technical assistance mission in April 1995 was updated in April 1999 and May 2000. The recommendations of the FAD missions, which had characterized government financial management as lacking discipline and transparency, are being implemented, as well as many of the measures recommended by recent audits of central government finances and domestic public debt. This should lead to improvements in the statistical database along the lines recommended by the STA mission.

The main deficiencies in government finance statistics relate to a lack of comprehensive coverage of the available data, involving notably treasury special accounts, ministries' own expenditures outside the budget, and social security operations. As a result of the 1999 audit of central government finances, the deficiencies are being corrected. Available estimates for 1997, 1998 and 1999 now reflect a comprehensive coverage of central government finances, although the social security operations are not included in government finances. Other needed improvements relate, inter alia, to the statistical treatment of oil companies' tax advances, the need to record in the budget accounts government investment financed by oil companies, and the recording of government domestic payment arrears.

Gabon does not report government finances statistics for publication in IFS and GFSY.

\section{Monetary statistics}

Monthly monetary data for Gabon, as well as for the other members of the Central African Economic and Monetary Community (CEMAC), are reported on a regular basis, although with some delays. The data are reported in electronic form by the regional central bank (BEAC) and published in International Financial Statistics (IFS). The institutional coverage of the monetary statistics is comprehensive, but accuracy is affected by crossborder movements of currency among CEMAC member countries. In the case of Gabon, however, the magnitude of imported notes is relatively small as compared with other countries in the region. About 95 percent of notes in Gabon are nationally issued; the remaining are from Congo, Cameroon, and Equatorial Guinea. Gabon exports more than 20 percent of its notes, most of which to Cameroon ( 11 percent) and to Congo ( 7 percent). 
The monetary and financial statistics mission that visited the BEAC headquarters (May 2001) provided technical assistance in addressing the main shortcomings pertaining to coverage, methodology, and timeliness of monetary statistics. The mission discussed an action plan for the implementation of the Monetary and Financial Statistics Manual and for the introduction of an area-wide page in IFS for the CEMAC. New proposals were discussed with the authorities for the provision of future technical assistance in monetary statistics for the region.

\section{External public debt}

Comprehensive data on the outstanding stock of external public debt and its composition, together with detailed projections on debt service due, are available and provided (usually to Fund missions) by the General Directorate of Public Debt and Accounting (Direction générale de la comptabilité publique) of the Ministry of Economy, Finance, Budget and Privatization. Comprehensive data on the composition of external public debt for the period prior to 1994 are not available.

\section{Balance of payments and trade statistics}

Annual data on exports and imports of goods and services and on capital flows other than the public debt are provided by the BEAC. Gabon reports annual balance of payments data to STA with a considerable lag. The most recent information on balance of payments statistics pertains to 1999 . The overall magnitude and detailed breakdown of private capital flows, particularly of short-term capital movements, suffer from a lack of comprehensiveness. Weaknesses in national accounts, poor source data, and inadequate coverage of the petroleum sector contribute to these limitations.

The multisector mission that visited Gabon during May 18-June 2, 1998, proposed several short- and medium-term recommendations on balance of payments statistics. The authorities have not reported the progress so far achieved in implementing the recommendations made by the multisector mission.

\section{Public enterprise sector}

While a fairly good database exists on the operations of public enterprises, information is communicated to the staff on an ad hoc basis, notably during Fund missions. The Fund has not yet received data for 1998 and 1999. At present, data provided cover only the wholly owned and mixed enterprises in which government equity participation is at least 25 percent. 
Gabon: Core Statistical Indicators

As of February 15, 2002

Date of latest

observation

Date received

Frequency of data

Frequency of

reporting

Source of data

Mode of reporting

Confidentiality

Frequency of publication

\begin{tabular}{|c|c|c|c|c|c|c|c|c|c|c|c|}
\hline $\begin{array}{l}\text { Exchange } \\
\text { Rates }\end{array}$ & $\begin{array}{l}\text { Intemational } \\
\text { Reserves }\end{array}$ & $\begin{array}{l}\text { Reserve/ } \\
\text { Base } \\
\text { Money }\end{array}$ & $\begin{array}{l}\text { Central } \\
\text { Bank } \\
\text { Balance } \\
\text { Sheet }\end{array}$ & $\begin{array}{l}\text { Broad } \\
\text { Money }\end{array}$ & $\begin{array}{l}\text { Interest } \\
\text { Rates }\end{array}$ & $\begin{array}{l}\text { Consumer } \\
\text { Price } \\
\text { Index }\end{array}$ & $\begin{array}{l}\text { Exports } \\
\text { and } \\
\text { Imports }\end{array}$ & $\begin{array}{l}\text { Current } \\
\text { Account } \\
\text { Balance }\end{array}$ & $\begin{array}{l}\text { Overall } \\
\text { Govern- } \\
\text { ment } \\
\text { Balance }\end{array}$ & $\begin{array}{l}\text { National } \\
\text { Accounts }\end{array}$ & $\begin{array}{l}\text { External } \\
\text { Debt }\end{array}$ \\
\hline
\end{tabular}

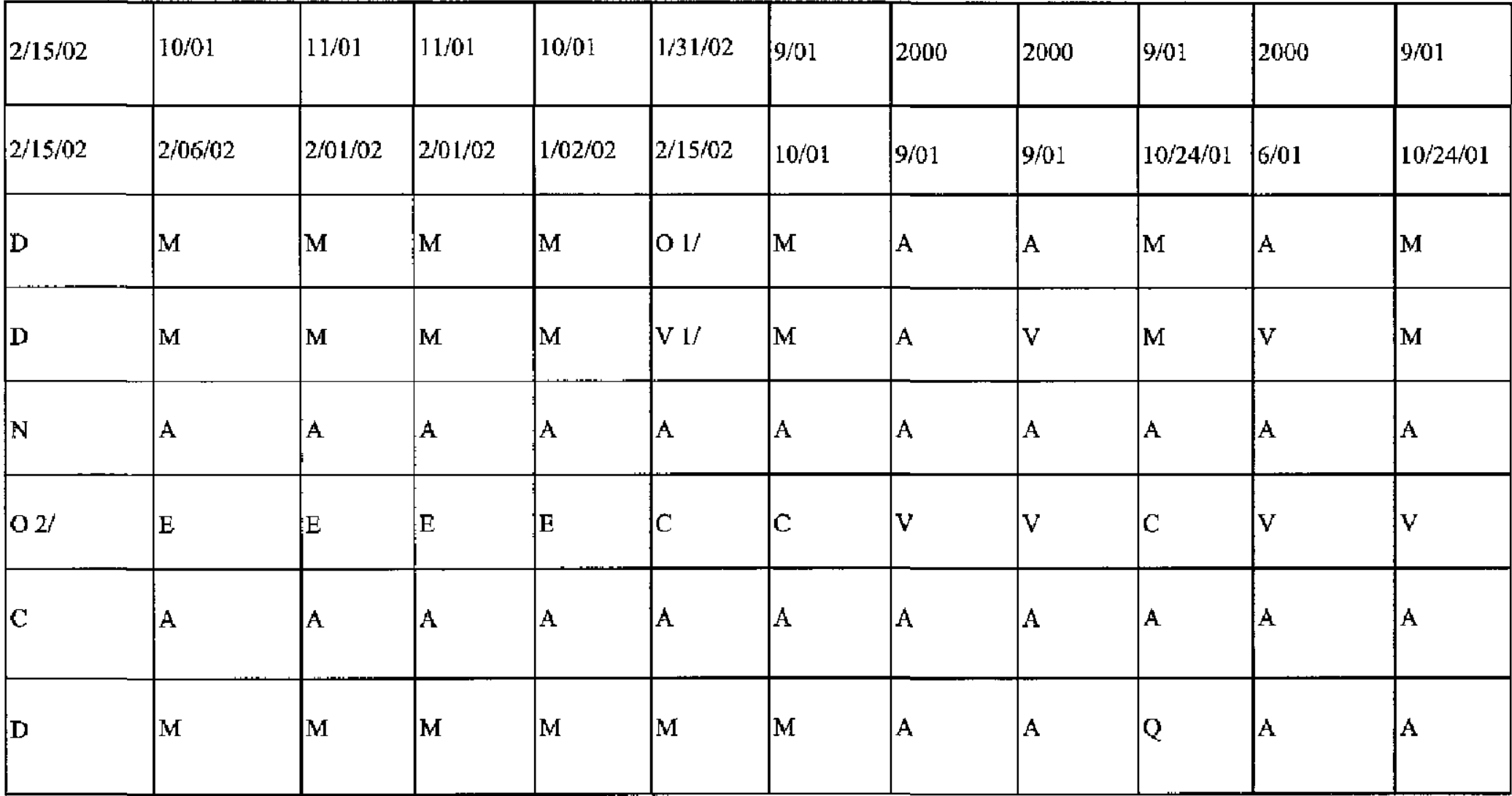

1/ Information communicated to staff as adjustments in interest rates occur.

2/ As reported in the daily morning press (euro crchange rate). 


\section{Statement by the IMF Staff Representative \\ April 1, 2002}

This statement provides information that has become available since the circulation of the staff report (SM/02/81) to the Executive Board on March 11, 2002. It does not alter the thrust of the staff appraisal.

1. Since the change of government in January 2002, no data on budget execution in 2002 have been communicated to staff. Nevertheless, there are indications that non-oil revenue during the first three months of 2002 is below expectation. Furthermore, external arrears are being incurred vis-à-vis bilateral creditors in 2002 in addition to the arrears outstanding at end-2001 (amounting to almost 2 percent of GDP), and government use of $\mathrm{BEAC}$ advances has remained close to the statutory ceiling.

2. The new Minister of Finance has expressed reservations on the reliability of the integrated budget information system (CRYSTAL). He ordered its suspension and an "audit" of the system is being carried out by two external experts. The system-introduced in early 2001 with FAD support-has been a key element of the government's program and has contributed to the improvement of the control and transparency of public finances (para. 18 of SM/02/81). Staff urges the authorities to address any problems of the system and move rapidly to its full implementation.

3. The preparation of a draft revised $\mathbf{2 0 0 2}$ budget has been slow (in part owing to the above-mentioned problems with Crystal), and may take several more weeks. One of the new tax measures introduced with the 2002 budget, adopted in November 2001, the "contribution for road development" (CRD), was recently suspended. The preparation of new tax measures, such as increasing domestic petroleum prices-instead of the CRD, as had been proposed by staff (see para. 27 of SM/02/81) - is still in an initial stage. To minimize the accumulation of payments arrears, tax collection needs to be improved and a strict cash management approach is imperative, as recommended in para 32 of SM/02/81.

4. With regard to Air Gabon, there has been progress with the conversion of the June 2001 contract to purchase four new planes into lease contracts. The authorities have confirmed the cancellation of the original purchase contract and the use of the down payment made last year for the lease payments for two $747 \mathrm{~s}$ and two $737 \mathrm{~s}$ (operational leases for five to seven years). The authorities are aware of the need to consider the net present value of projected lease payments as potential nonconcessional debt, in line with the 2000 Guidelines on Performance Criteria with Respect to Foreign Debt.

5. Compared to the situation described in para. 20 of SM/02/81, further delays are expected in the adoption of the draft anticorruption laws. The authorities have indicated that they share the staff's concerns on previous draft laws. With the help of a United Nations' expert, they are preparing revised draft anticorruption laws to be submitted to parliament in due course. To that effect, they have decided not to promulgate the draft laws adopted by the 
National Assembly and the Senate, currently under reconciliation by the joint parliamentary committee. With regard to the petroleum audits, the financial audits for the two main petroleum companies (Elf and Shell) were launched this month, together with those for two smaller companies (Amerada-Hess and Perenco), all by an international auditing firm (para. 18 of SM/02/81). 
Public Information Notice (PIN) No. 02/50

FOR IMMEDIATE RELEASE

May 3, 2002
International Monetary Fund

$70019^{\text {th }}$ Street, NW

Washington, D. C. 20431 USA

\section{IMF Concludes 2001 Article IV Consultation with Gabon}

On April 1, 2002, the Executive Board of the International Monetary Fund (IMF) concluded the Article IV consultation with Gabon. ${ }^{1}$

\section{Background}

Since the severe financial crisis of 1998 , Gabon has made considerable progress in putting public finances on a sound footing, reducing government indebtedness, and regularizing relations with external and domestic creditors. Fiscal and structural reform efforts continued during 2001 under the government's program supported by an 18-month Stand-by Arrangement, approved on October 23,2000. After the conclusion of the first and the second quarterly reviews in July 2001, remaining program reviews could not be concluded, owing mainly to fiscal underperformance and delays in structural reforms (notably in the governance area).

Non-oil economic activity in Gabon rose by 4 percent in 2001, following a severe contraction in 1999 and a moderate recovery in 2000 . Private investment picked up as confidence strengthened further, helped by substantial repayments of government domestic debt. Services, agriculture, and wood processing were the main sectors contributing to growth. Oil production fell to 13 million tons (from 13.5 million tons in 2000); this drop was significantly less than anticipated, as high oil prices rendered exploitation of marginal fields profitable. Overall real

\footnotetext{
${ }^{1}$ Under Article IV of the IMF's Articles of Agreement, the IMF holds bilateral discussions with members, usually every year. A staff team visits the country, collects economic and financial information, and discusses with officials the country's economic developments and policies. On return to headquarters, the staff prepares a report, which forms the basis for discussion by the Executive Board. At the conclusion of the discussion, the Managing Director, as Chairman of the Board, summarizes the views of Executive Directors, and this summary is transmitted to the country's authorities. This PIN summarizes the views of the Executive Board as expressed during the April 1, 2002 Executive Board discussion based on the staff report.
} 
GDP growth is estimated at $1 \frac{1}{2}$ percent in 2001; and consumer price inflation remained subdued, at 1 percent during the 12-month period ending December 2001.

Helped by high oil prices, the external current account balance improved from a deficit of 8.8 percent of GDP in 1999 to a surplus of 3.2 percent in 2000, before turning to a deficit of 1 percent of GDP in 2001, mainly on account of lower oil exports and higher external interest.

During 2000-01, Gabon made significant progress in improving public finances, with the primary fiscal surplus averaging some 17 percent of GDP. However, fiscal performance in 2001 fell short of the government's objective, owing mainly to weaknesses in non-oil revenue collection, unbudgeted support for public enterprises, and a relaxation of expenditure controls, in particular, toward the end of the year. As a result, unprogrammed use of bank credit by the government amounted to 4 percent of GDP in 2001, contributing to a substantial drop in Gabon's net foreign assets. This development largely reversed the progress made on both accounts in 2000 , when the government was able to save a large part of the windfall oil revenue.

There was progress in several structural reform areas, notably in expenditure management (with the introduction of a new integrated budget information system), the regulatory framework (with the adoption of the new labor code in late 2000 and the new forestry code in 2001), as well as civil service reform and governance (with the preparation of several key texts). However, delays were recorded in the privatization of public enterprises (in the agro-industry, telecommunications, and air transport sectors) and the adoption of the draft anticorruption laws and the Code of Ethics for civil servants. Further-more, the audits of the oil companies have not been completed and the initiation of the civil service reform is awaiting the adoption of the relevant texts.

A rescheduling agreement (on nonconcessional terms), reached with Paris Club creditors in December 2000, allowed the consolidation of debt service in arrears equivalent to about 12 percent of GDP. Nevertheless, Gabon's external debt service burden will continue to claim some 40 percent of government revenue in 2002 and beyond.

Gabon's challenges in the medium-term are the projected rapid decline in oil production and the continued high external debt service burden. Prospects for sustained growth and poverty reduction depend on the development of the nonoil sector. This objective will require significant efforts to mobilize domestic savings, enhanced access to foreign financing, and further improvements in the environment for private sector activity.

\section{Executive Board Assessment}

Executive Directors noted that the authorities had continued their efforts in the past year to put public finances on a sound footing, reduce public debt, and instill in creditors and the private sector confidence in government policies. Directors expressed concern about the fiscal slippages relative to the program and the delays in governance-related structural reforms. They regretted that many objectives of the program could not be attained as planned, and that most 
of the reviews under the stand-by arrangement were not completed, although a few Directors thought that the program might have been over-ambitious.

Directors recognized that the authorities had made impressive efforts to move the economy toward the path of medium-term sustainability, to re-establish good relations with creditors, and to embark on the elaboration of a nationally-initiated, UNDP-assisted poverty reduction strategy. The authorities' success in effecting a rapid turnaround from a large fiscal deficit in previous years to a large primary surplus in 2001, which had enabled the reduction of government debt, was particularly noteworthy. Nevertheless, many Directors noted that Gabon had started from a low base in respect of structural reform, fiscal transparency and accountability, and governance. While they welcomed the recent indications by the authorities that these weaknesses would be addressed, they expressed concern that a number of important measures relating to structural reforms, administrative capacity improvements, and measures relating to strengthening of governance were behind schedule. Directors expressed particular concern at the delays in adopting the anti-corruption laws, and called on the authorities to press forward resolutely with governance reforms.

In light of the depletion of oil resources in the medium term and the resulting fall in government revenues, Directors stressed that prospects for growth and poverty reduction in the medium term depend critically upon the extent to which the non-oil sector will replace oil and the government sector as the engine for growth. Significant efforts are needed to mobilize domestic and foreign savings and to create investment incentives for the private sector, including through the creation of a more business-friendly environment, and improved governance. Directors urged the authorities to fully implement the forestry reform and adapt national laws to the OHADA Uniform Acts, to alleviate the burden on private business of price controls and quasifiscal levies, and to reform the judicial system.

Directors highlighted the high external debt service payments that will face Gabon in 2002 and the next few years and were concerned about the recent buildup in arrears to bilateral creditors. They stressed the importance of alleviating the debt constraint by spreading amortization obligations over a longer period. In this regard, they emphasized the importance of continuing fiscal consolidation and seeking rescheduling of debt-of which much was on non-concessional terms-from bilateral creditors.

Directors welcomed the improvement in public finances over the past three years, reflected in the large primary surpluses recorded in 2000-01, and the resulting significant reduction in government debt, but regretted the shortcomings in fiscal program implementation in 2001 . In that connection, oil revenue had exceeded the program target by only a small amount even though both oil prices and production volumes had been significantly higher than anticipated, and no oil receipts had been deposited in the Fund for Future Generations. The large unforeseen transfers to pubtic enterprises and outflows from treasury accounts were also a cause of concern. Directors stressed the importance of strengthening expenditure control and enhancing program monitoring. 
Directors encouraged the authorities to adopt without delay a revised budget for 2002 that is financeable and consistent with a poverty reduction strategy. They emphasized the importance of directing government spending toward social and physical infrastructure, containing the wage bill, and proceeding with the civil service reform. Directors stressed the need to increase non-oil revenue, in particular through efficient new tax measures with regard to domestic petroleum consumption and improved customs administration. Directors urged the authorities to improve the transparency of oil revenue collection, and to set aside part of oil revenues in the Fund for Future Generations. The prompt completion of the financial audits of all oil companies, and the undertaking of such audits on an annual basis, will be essential.

Directors welcomed the progress made in 2001 in public expenditure management, including the design and gradual implementation of the integrated budget information system (CRYSTAL). Directors noted that the present system did not cover most treasury accounts, including the so-called special funds, and was suspended earlier this year because of technical difficulties. They urged the authorities to implement fully the budget information system, and welcomed the authorities' confirmation of their commitment to transparent monitoring of the budget execution.

Directors advised the authorities to renew the momentum of the privatization process, as a crucial component of private sector development, and to avoid the drain on budgetary resources originating in unanticipated payments in support of the remaining state enterprises. Regarding the state-owned airline, they welcomed the authorities' decision to seek the conversion of the frozen contract to purchase new planes into a lease contract, and urged them to vigorously pursue their plans to privatize the company.

Directors welcomed the authorities' intention to further improve the supervision of the financial sector, taking into account the recommendations of the recent Financial System Stability Assessment, and of the importance of effectively deterring money laundering and the financing of terrorism. They also encouraged the authorities to vigorously pursue reform of the social security system.

Directors noted that Gabon needs to correct deficiencies in its data provision to the Fund. They welcomed the authorities' recent decision to participate in the GDDS.

Directors urged the authorities to formulate and implement a new economic program embodying renewed fiscal and structural reform momentum that could obtain the support of the international community. They stressed that some of the main elements of such a program should be adoption of a revised 2002 budget consistent with fiscal sustainability and poverty reduction, and implementation of measures to strengthen governance. A few Directors stressed that it would be important that a new program be realistic and achievable, and noted that the recent decision of the Fund to streamline conditionality could be of great relevance in the future retationship between Gabon and the Fund. 
Public Information Notices (PINs) are issued, (i) at the request of a member country, following the conclusion of the Article IV consultation for countries seeking to make known the views of the IMF to the public. This action is intended to strengthen IMF surveillance over the economic policies of member ccuntries by increasing the transparency of the IMF's assessment of these policies; and (ii) following policy discussions in the Executive Board at the decision of the Board. The Staff Report for the 2001 Article IV Consultation with Gabon is also available. 
Gabon: Selected Economic and Financial Indicators, 1998-2001

\begin{tabular}{|c|c|c|c|c|}
\hline & 1998 & 1999 & 2000 & $\begin{array}{r}2001 \\
\text { Est. }\end{array}$ \\
\hline & \multicolumn{4}{|c|}{ (Annual percent change) } \\
\hline \multicolumn{5}{|l|}{ Domestic economy } \\
\hline Real GDP growth & 3.5 & -9.6 & -1.9 & 1.5 \\
\hline Consumer price inflation, end-of-period & 2.6 & -0.8 & 1.8 & 1.0 \\
\hline \multirow[t]{2}{*}{ Consumer price inflation, average } & 2.3 & -0.7 & 0.4 & 2.1 \\
\hline & \multicolumn{4}{|c|}{ (In percent of GDP)1/ } \\
\hline \multicolumn{5}{|l|}{ Financial variables } \\
\hline Total revenue (excluding grants) & 34.5 & 28.7 & 33.8 & 35.1 \\
\hline Total expenditure & 48.5 & 27.5 & 22.0 & 27.6 \\
\hline Overall balance (commitment basis) & -14.0 & 1.2 & 11.8 & 7.6 \\
\hline Primary balance (excluding foreign grants) & -6.3 & 8.1 & 17.7 & 16.5 \\
\hline External public debt (including IMF) & 77.9 & 81.1 & 64.7 & 58.5 \\
\hline Broad money (percent change) & -1.8 & -2.7 & 18.0 & 7.5 \\
\hline Interest rate (in percent) 2 I & 7.0 & 7.6 & 7.0 & 6.5 \\
\hline \multirow{3}{*}{$\begin{array}{l}\text { Real effective exchange rate, percent change } \\
\text { (annual period average, - = depreciation) }\end{array}$} & & & & \\
\hline & 3.4 & -4.4 & -6.9 & 1.7 \\
\hline & \multicolumn{4}{|c|}{ (In millions of U.S. dollars) $1 /$} \\
\hline Exports, f.o.b. & $1,906.7$ & $2,504.5$ & $3,218.5$ & $2,633.6$ \\
\hline Imports, f,o.b. & $-1,102.9$ & -847.8 & -926.8 & -998.5 \\
\hline External current account balance & -839.1 & -408.3 & 163.2 & -48.7 \\
\hline In percent of GDP & -18.7 & -8.8 & 3.2 & -1.1 \\
\hline
\end{tabular}

Sources: Gabonese authorities; and IMF staff estimates and projections.

1/ Unless otherwise indicated.

2/ Bank of Central African States' auction rate (TIAO), at year end. 